\author{
University of Szeged \\ Faculty of Pharmacy \\ Graduate School of Pharmaceutical Sciences \\ Department of Pharmacognosy
}

\title{
Activity-guided investigation of antiproliferative secondary metabolites of Asteraceae species
}

\author{
Ph.D. Thesis \\ Boglárka Csupor-Löffler \\ Supervisors: \\ Prof. Judit Hohmann \\ Dr. Zsuzsanna Hajdú
}

Szeged, Hungary

2012 


\section{TABLE OF CONTENTS}

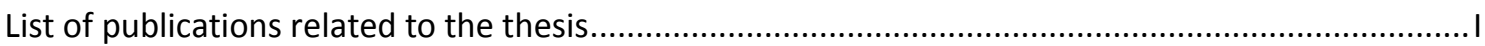

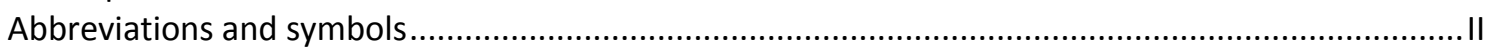

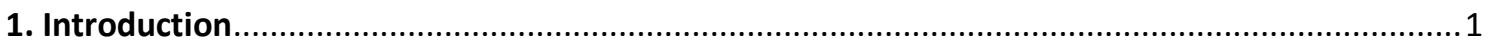

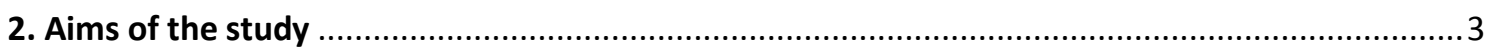

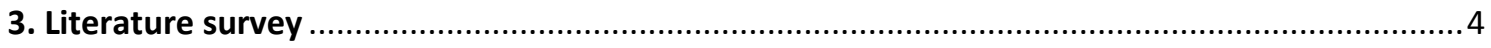

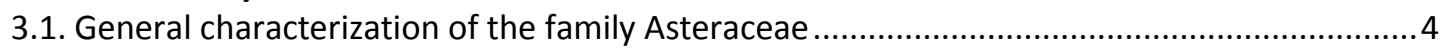

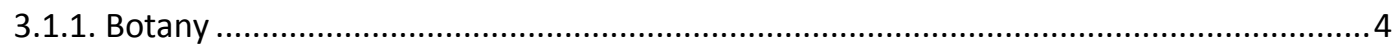

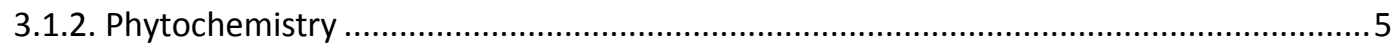

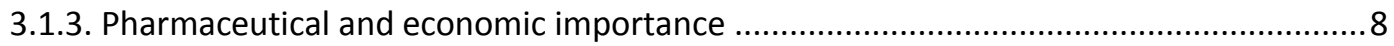

3.2. Literature data on asteraceae species with anticancer properties .........................................9

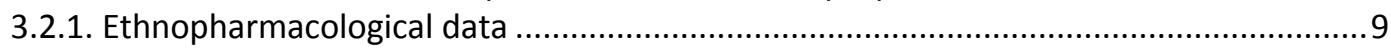

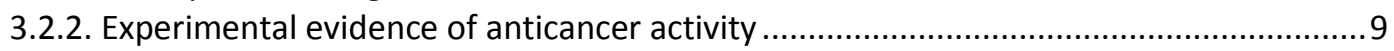

3.3. Characterization of plant species investigated in detail.....................................................11

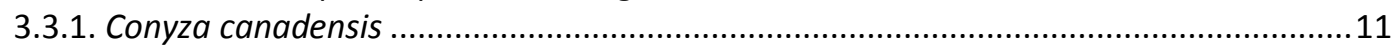

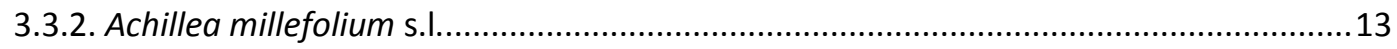

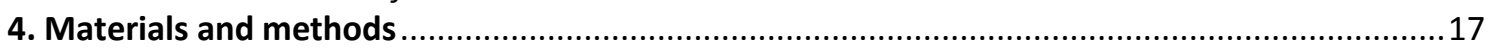

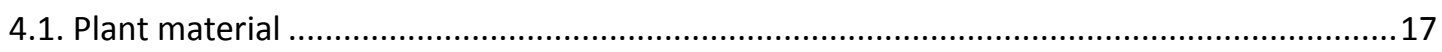

4.1.1. Plants for antiproliferative screening ...................................................................

4.1.2. Plants for activity-guided investigation..................................................................... 17

4.2. Tribal division of plants for the assessment of the screening study .....................................17

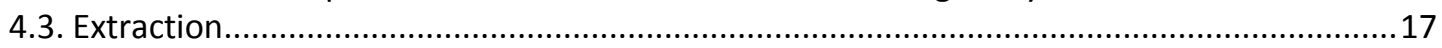

4.3.1. Preparation of extracts for antiproliferative screening ...............................................17

4.3.2. Extraction of plant materials for activity-guided investigation .......................................18

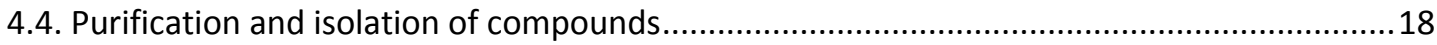

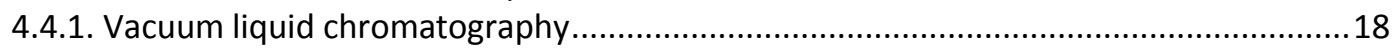

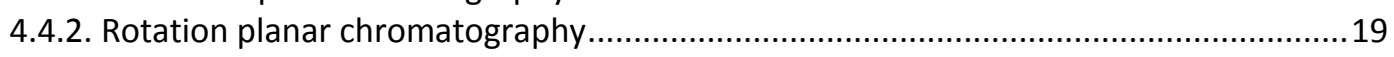

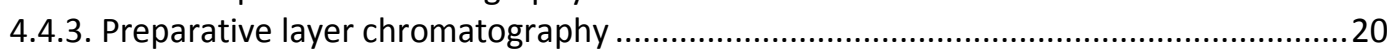

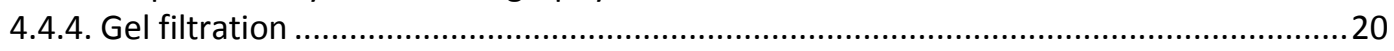

4.4.5. High-performance liquid chromatography ............................................................20

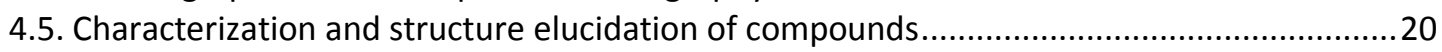

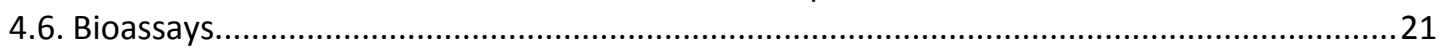

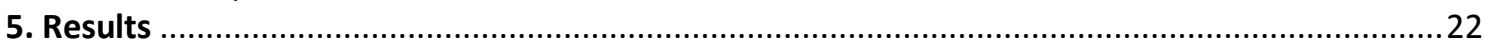

5.1. Screening of the Hungarian Asteraceae for antitumour effects ..........................................22

5.2. Antiproliferative effects of plants selected for bioactivity-guided investigations ...................24

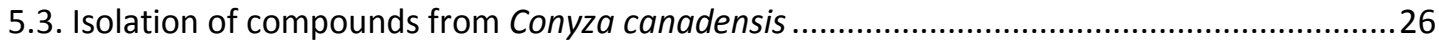

5.4. Isolation of compounds from Achillea millefolium s.l. ..........................................................28

5.5. Characterization and structure determination of the isolated compounds .........................30

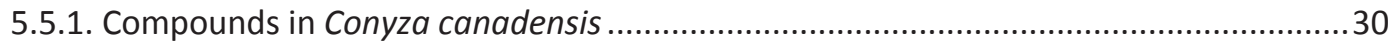

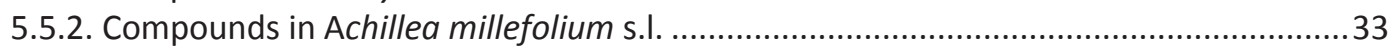

5.6. Pharmacological assessment of the isolated compounds................................................... 35

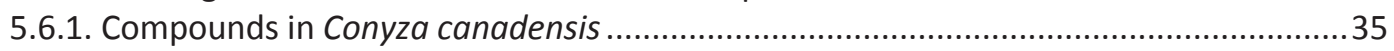

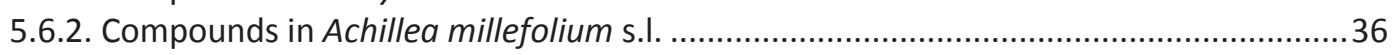

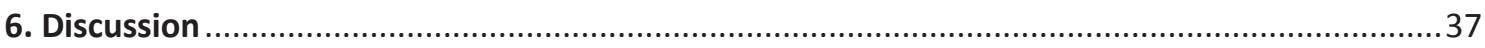

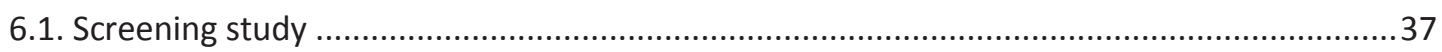

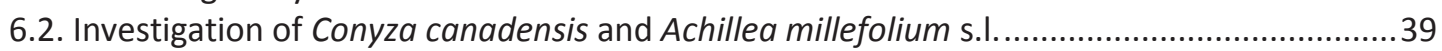

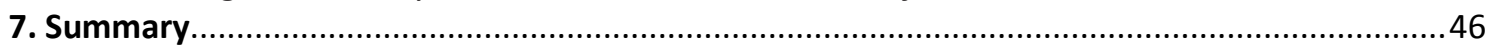

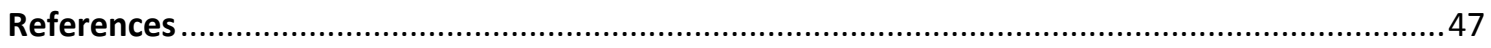

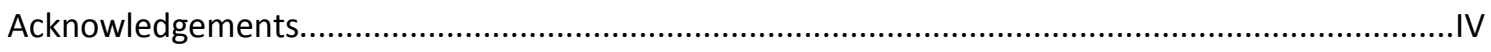

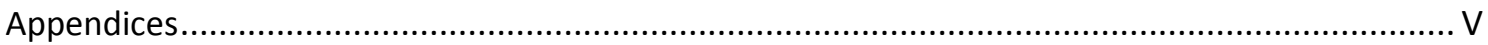




\section{LIST OF PUBLICATIONS RELATED TO THE THESIS}

I. Réthy B, Csupor-Löffler B, Zupkó I, Hajdú Z, Máthé I, Hohmann J, Rédei T, Falkay G.

Antiproliferative activity of Hungarian Asteraceae species against human cancer cell lines. Part I

Phytotherapy Research 21: 1200-1208 (2007)

II. Csupor-Löffler B, Hajdú Z, Réthy B, Zupkó I, Máthé I, Rédei T, Falkay G, Hohmann, J.

Antiproliferative activity of Hungarian Asteraceae species against human cancer cell lines. Part II Phytotherapy Research 23: 1109-1115 (2009)

III. Csupor-Löffler B, Hajdú Z, Zupkó I, Réthy B, Falkay G, Forgo P, Hohmann J.

Antiproliferative effect of flavonoids and sesquiterpenoids from Achillea millefolium s.I. on cultured tumour cell lines

Phytotherapy Research 23: 672-676 (2009)

IV. Csupor-Löffler B, Hajdú Z, Zupkó I, Molnár, J, Forgo, P, Vasas, A, Kele, Z, Hohmann, J. Antiproliferative constituents of the roots of Conyza canadensis

Planta Medica 77: 1183-1188 (2011) 


\section{ABBREVIATIONS AND SYMBOLS}

A-431 human skin epidermoid carcinoma cells

A-549 human lung basal epithelial adenocarcinoma cells

ATCC

American type culture collection

$\mathrm{Al}_{2} \mathrm{O}_{3} \quad$ aluminium oxide

Bcl-2 B-cell leukemia/lymphoma protein-2

$\mathrm{CH}_{2} \mathrm{Cl}_{2}$ dichloromethane

$\mathrm{CHCl}_{3} \quad$ chloroform

COSY correlated spectroscopy

1D

one-dimensional

$2 \mathrm{D}$

two-dimensional

e.g.

for example

EtOAc ethyl acetate

GF

gel filtration

G2 phase

gap 2 pre-mitotic phase of the cell cycle

HeLa human cervix adenocarcinoma

HEp-2 human larynx epidermoid carcinoma

$\mathrm{HMBC}$ heteronuclear multiple-bond correlation

HPLC High-performance liquid chromatography

HREIM high-resolution electron ionization mass spectrometry

HRMS high-resolution mass spectrometry

$\mathrm{H}_{2} \mathrm{SO}_{4}$ sulfuric acid

HT-29 human colorectal adenocarcinoma cells

HSQC heteronuclear single-quantum correlation

i.e. in other words

JMOD J-modulated spin-echo experiment

$\mathrm{kB}$ human nasopharynx epidermoid cancer cells

L-210 mouse lymphocytic leukemia cells

MCF-7 human breast adenocarcinoma cells

$\mathrm{Me} \quad$ methyl

$\mathrm{MeOH} \quad$ methanol

m.p. melting point

M phase mitotic phase of the cell cycle

MAPK mitogen-activated protein kinase

MRC-5 human foetal lung fibroblast cells 


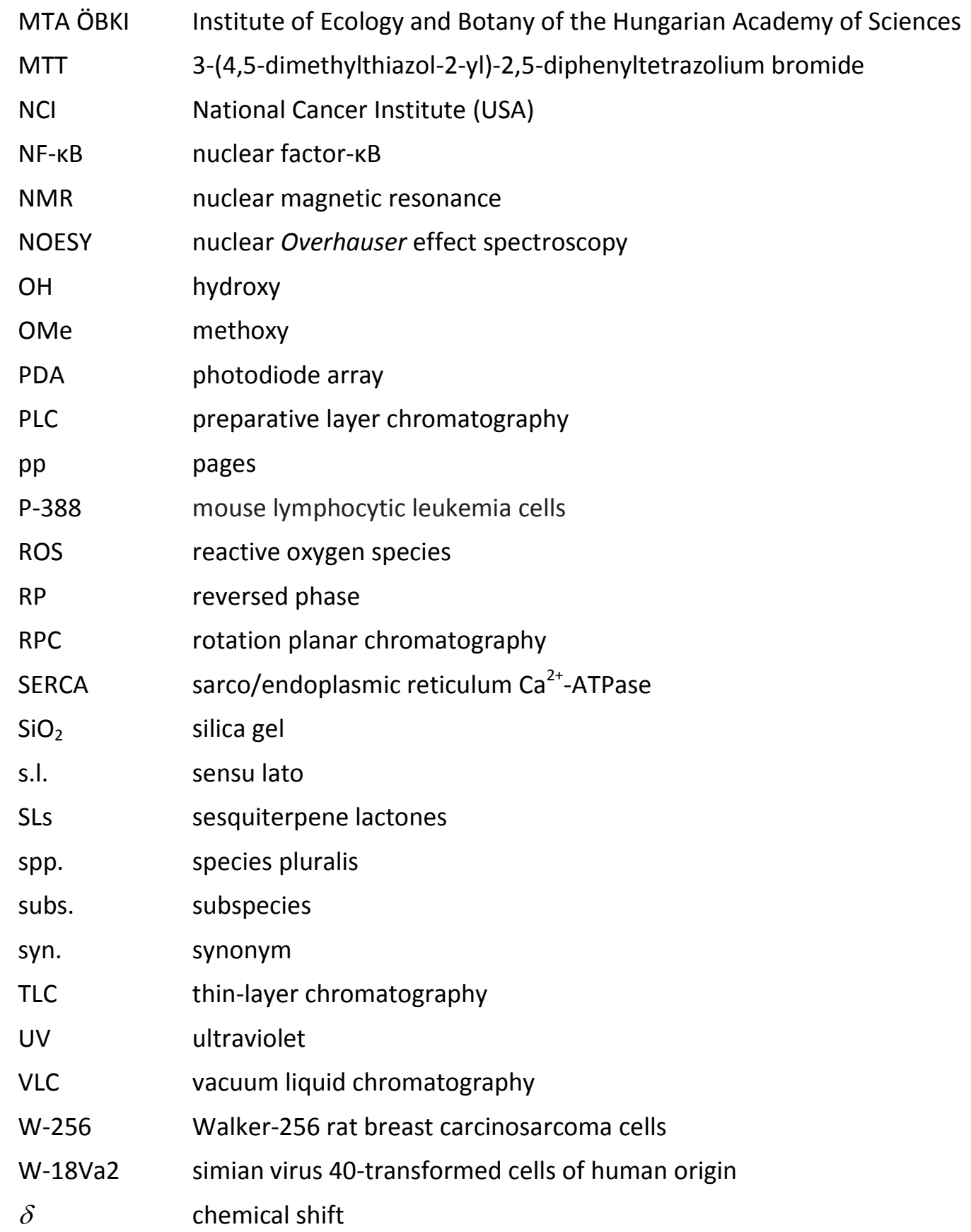




\section{INTRODUCTION}

The screening of natural products plays a considerable role in the discovery of new biologically active compounds and hence in the development of drugs for cancer chemotherapy. In the past few decades, numerous useful antineoplastic drugs (e.g. taxoids, campthotecine, podophyllotoxin derivatives and Vinca alkaloids) have been discovered in higher plants by following up ethnomedicinal uses or the results of antitumour screening. Among currently available anticancer drugs, more than $60 \%$ of the new small molecular chemical entities are non-synthetic, a proportion which is much higher than in other areas of drug development. ${ }^{1,2}$

The ongoing search for naturally occurring anticancer agents is still very intense, and numerous lead compounds of natural origin are under investigation in clinical studies. The approval of ingenol3-angelate (1), a cytotoxic diterpene ester from Euphorbia peplus, as a new drug (Picato ${ }^{\circledR}$ ) indicated for the topical treatment of actinic keratosis, illustrates the success of this pursuit. ${ }^{3} \mathbf{1}$ is also participating in phase II trials for the treatment of basal cell carcinoma. ${ }^{4}$ Another perspective molecule, flavopiridol (2), a synthetic flavone derivative structurally based on the natural product rohitukine (3) isolated from Dysoxylum binectariferum, is currently reported to be involved in 9 clinical trials ranging from phase I to phase II, covering leukaemias, lymphomas and solid tumours. Thapsigargin (4), a sesquiterpenoid from Thapsia garganica, has shown promise in a phase I trial as a chemotherapeutic drug against advanced solid tumours. ${ }^{4}$

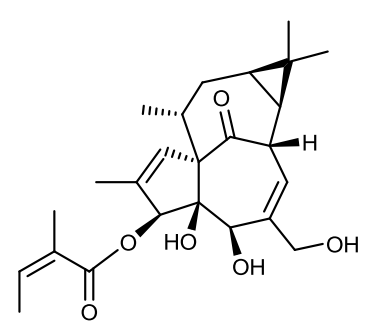

1

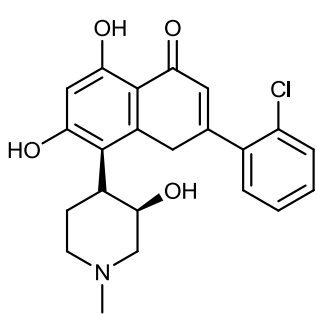

2

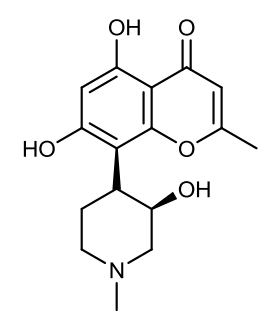

3

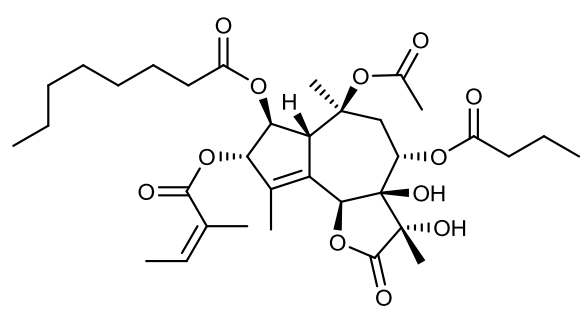

4

The process that leads from a plant to the production of a potential antitumour compound includes the selection of the plants for investigation, the primary screening of the plant extracts and the subsequent bioactivity-guided fractionation, comprising several consecutive steps of chromatographic separation, where each fraction obtained has to be submitted to bioassays in order to follow the activity. For the bioassays, a broad variety of cultured cancer cell lines of human or animal origin are available as targets. After the isolation procedures, characterization and pharmacological evaluation of the pure compounds have to be carried out. ${ }^{5,6}$ 
Plants can be selected for screening on the basis of ethnobotanical information or chemotaxonomic relationships to medicinal plants with anticancer properties. In the surveys by HARTWELL and GRAHAM on plants which had been reported to have ethnomedical uses for cancer-related diseases, data on about 300 species of Asteraceae were surveyed. ${ }^{7,8}$ The antitumour effects of Asteraceae species have been extensively studied, and sesquiterpene lactones or flavonoids have frequently been demonstrated to be responsible for their antitumour action. ${ }^{9-13}$ Several of these molecules are undergoing human studies as potential chemotherapeutic agents (artemisininoids, parthenolides and silibinin) or are regarded as good candidates for clinical trials (apigenin, eupatoriopcrin, helenanolides and xanthanolides). ${ }^{12,14-17}$

Although appreciable experimental evidence and ethnobotanical data are available concerning the anticancer properties of Asteraceae species, only a few screening studies have been reported on the plants from this family, and none at all on the European species. The present work comprises an evaluation of the antitumour effects of plants from the Hungarian Asteraceae and detailed phytochemical investigations of Conyza canadensis (L.) CRONQ. and Achillea millefolium s.l. 


\section{AIMS OF THE STUDY}

In recent years, the research group of the Department of Pharmacognosy at the University of Szeged has initiated a programme in collaboration with the Department of Pharmacodynamics and Biopharmacy at the same university, with the purpose of obtaining potential antineoplastic compounds from the Hungarian flora. As part of this project, the aim of the present work was to carry out a comprehensive anticancer screening of Asteraceae species found in Hungary, and to identify the antitumour compounds present in certain selected plants. In order to achieve these goals, my main tasks were to

- review the literature on Asteraceae, concerning the chemistry and antitumour properties of the plants;

- collect plant material for the antitumour screening study of Asteraceae species native to Hungary;

- prepare samples for the screening study, and subject the collected plants to extraction with different solvents;

- examine the tumour cell proliferation-inhibitory activities of the extracts (carried out in the Department of Pharmacodynamics and Biopharmacy);

- select species with high antiproliferative activity, considered worthy of detailed phytochemical studies;

- collect plant material of the selected species for preparative work;

- extract the plant material;

- isolate the compounds responsible for the antiproliferative effects via bioactivity-directed fractionation, using various chromatographic techniques;

- elucidate the structures of the isolated compounds by NMR and MS methods, provide characteristic spectral data on the isolated new compounds, and supplement missing NMR data on the already-known constituents;

- evaluate the pharmacological potential of the isolated compounds (carried out in the Department of Pharmacodynamics and Biopharmacy). 


\section{LITERATURE SURVEY}

\subsection{General Characterization of the family Asteraceae}

The Asteraceae (formerly Compositae; sunflower family) comprise the largest family of flowering plants, with over 1600 genera and 23000 species. ${ }^{18}$ Members of the Asteraceae, named sunflowers, are distributed throughout the world and occupy a wide range of habitat. They are exceptionally rich in secondary metabolites which serve as storage compounds or as chemical defenders. The development of their morphological and chemical complexity has contributed to the evolutionary success of the Asteraceae, and the rich chemistry of the family is the basis of their very widespread use as medicinal plants. ${ }^{18,19}$

\subsubsection{Botany}

\section{Morphology}

Sunflowers are mostly herbaceous plants, but a significant number are also subshrubs or shrubs, and less often trees. Underground storage organs are common in perennial herbaceous and shrubby forms and may be represented by thickened taproots, root tubers, tuberous rhizomes or lignotubers. The leaves can be alternate or opposite, rarely whorled; the lamina is usually simple but often lobed or divided. Internal secretory systems (schizogenous secretory canals or articulated lacticifers) may be present in both the vegetative and reproductive organs. ${ }^{18}$

The family is characterized by a special inflorescence consisting of flowers aggregated into capitula. The capitulum (head), surrounded by an involucre of protective bracts, is the functional flower and usually acts as a single attraction unit. It can contain flowers (florets) with corollas of the same morphology (homogamous head) or a combination of several types of corollas (heterogamous head with disc and ray florets). The florets, sitting on the expanded receptacle, may display either actinomorphic or zygomorphic symmetry. The calyx is often replaced by a pappus of variable structure; it can also be reduced or completely absent. The corollas have five petals fused the base to form a corolla-tube. They can occur in various forms; the basic types are tubular, bilabiate, radiate and ligulate corollas, classified on the basis of the arrangement of the lobes. There are usually 5 stamens in sunflowers, featured by filaments inserted on the corolla-tube and by anthers united into a tube surrounding the style. The latter is built up from 2 fused carpels; the ovary is inferior and unilocular, with 1 basal ovule. The fruit is 1-seeded, normally an achene or very rarely a drupe. It is often apically crowned by the persistent pappus, derived from the calyx, which assists in dispersal. ${ }^{18,20,21}$ 


\section{Intrafamilial classification}

The main conception used to classify sunflowers is the tribal division which was introduced by BENTHAM in $1873 .{ }^{19}$ The 13 tribes of the family were grouped much later by CARLQUIST (1966) and WAGENITZ (1976), who defined 2 subfamilies, such as Cichorioideae and Asteroideae. These classifications were mostly based on the floral structures. ${ }^{22}$ In 1994, with the use of information from molecular systematics and chemotaxonomy, BREMER recognized 17 tribes and defined a new subfamily, Barnadesioideae, as a small monotribal group with only 91 species, endemic to South America. ${ }^{23}$ In the most recent classification, by JEFFREY, ${ }^{18}$ the tribes of Asteraceae, now expanded to 24, can be grouped into 5 subfamilies (Figure 1). The largest subfamily is that of Asteroideae, which comprises 17000 species in 8 tribes, found in abundance in all continents except Antarctica.

I. BARNADESIOIDEAE
1. Barnadesieae
II. MUTISIOIDEAE
1. Stifftieae
2. Mutisieae

III. CARDUOIDEAE
1. Gochnatieae
2. Hecastocleideae
3. Tarchonantheae
4. Dicomeae
5. Cynareae syn. Cardueae
6. Pertyeae

IV. CICHORIOIDEAE

1. Gymnarrheneae

2. Moquinieae

3. Vernonieae

4. Liabeae

5. Cichorieae syn. Lactuceae

6. Gundelieae

7. Arctotideae

\author{
V. ASTEROIDEAE \\ 1. Corymbieae \\ 2. Senecioneae \\ 3. Calenduleae \\ 4. Gnaphalieae \\ 5. Astereae \\ 6. Anthemideae \\ 7. Inuleae \\ 8. Heliantheae
}

Figure 1. Subfamilies (bold) and tribes (italics) of Asteraceae according to JeFFREY ${ }^{18}$

\subsubsection{Phytochemistry}

Although no single class of constituent is unique to the family, the Asteraceae are unlike any other family in the array of their characteristic constituents. ${ }^{22}$ Sesquiterpene lactones (SLs), pentacyclic triterpene alcohols, fatty acid-derived acetylenic compounds, methylated flavonols and flavones, inulin-type fructans and fatty oils in the seeds are common constituents of many species and predominate in the chemical make-up of the family. Essential oils and diterpenoids are also widely distributed. Alkaloids, cyanogenic glycosides, amides, coumarins and several types of phenolic constituents exhibit a much more limited distribution. ${ }^{24}$

\section{Sesquiterpene lactones}

The bitter-tasting SLs, with over 3000 reported structures, are the most characteristic class of chemicals in sunflowers. These $C_{15}$ isoprenoid constituents are found mainly in the leaves, excreted in the subcuticular cavities of the glandular hairs or deposited in the latex; their ecological role in plants is defence against herbivores and parasites. ${ }^{15,24}$ SLs are represented in sunflowers by several polycyclic systems possessing a lactone ring as major structural feature, which is often an $\alpha, \theta$ unsaturated $\gamma$-lactone. Many lactones also contain an $\alpha, \beta$-unsaturated carbonyl or epoxide group. ${ }^{25}$ 
Biogenetically, they are formed from E,E-farnesyl pyrophosphate following an initial cyclization and a subsequent oxidative modification. ${ }^{26}$ Germacranolides form the most fundamental group; other SLs, with only a few exceptions, are transformation products of this type (Figure 2). ${ }^{27}$

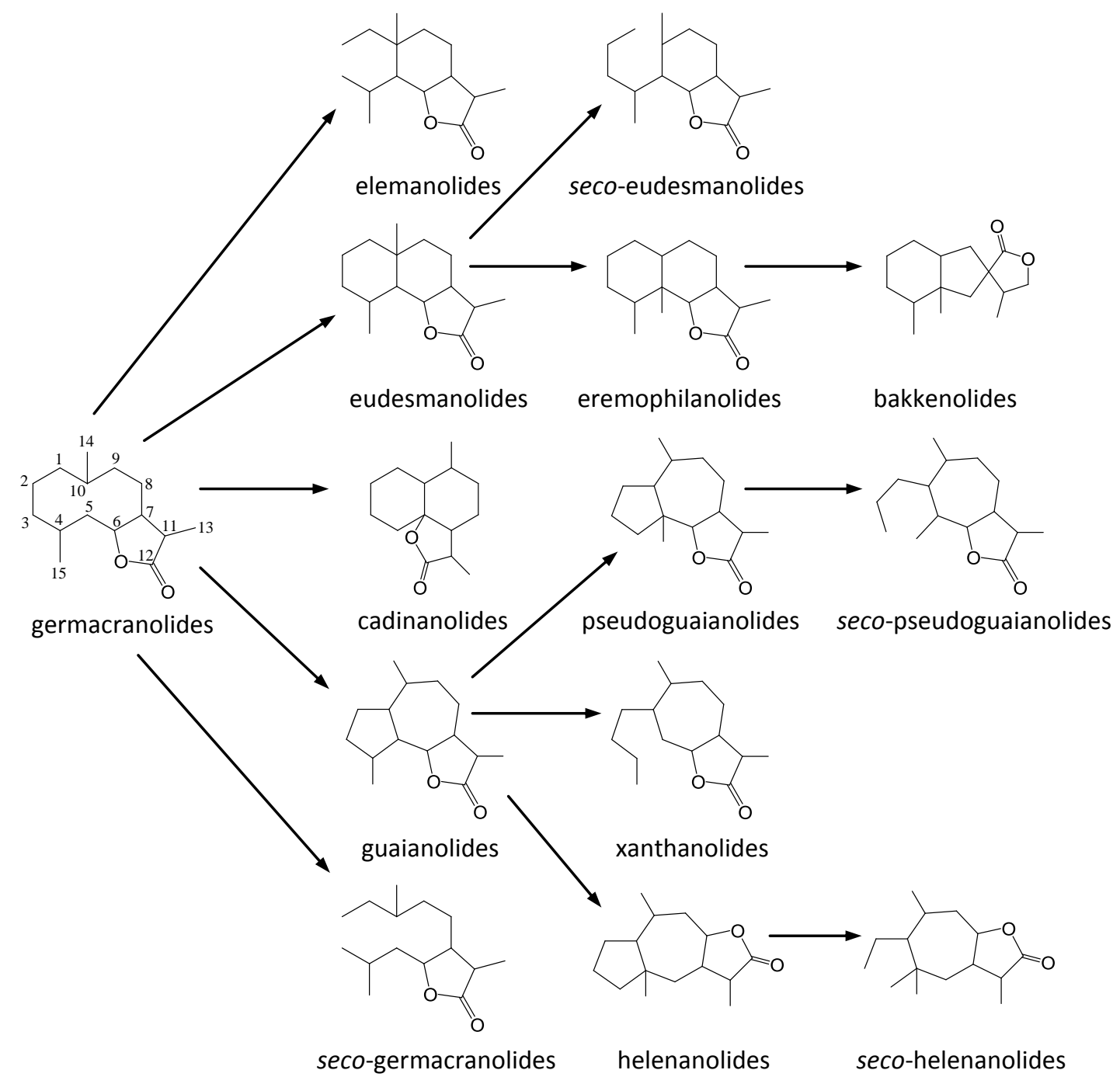

Figure 2. Biogenesis of the main structural types of sesquiterpene lactones

In the asteroid tribes, SLS are present with considerable structural diversity: germacranolides, guaianolides, eudesmanolides and elemanolides, the most frequently encountered types, occur commonly in many species, while the presence of other derivatives is restricted to certain tribes, such as cadinanolides in Anthemideae or pseudoguaianolides (ambrosanolides), helenanolides and xanthanolides in Heliantheae and Inuleae. The Senecioneae are very distinct in their development of 
furanoeremophilanolides. The SLS chemistry of the non-asteroid tribes is generally less complex: the main structural types are guaianolides and germacranolides; SLS are totally absent from the barnadesioid species. ${ }^{18,26}$

\section{Triterpenes}

Monools and diols of oleanane [e.g. $\alpha$-amyrin (5)], ursane [e.g. arnidiol (6)] or lupane [e.g. calenduladiol (7)] triterpenes are typical constituents of Asteraceae. They occur in free form or esterified with acetic acid in the lipid fractions of the vegetative and reproductive organs or in the latex. In certain taxa (e.g. Calendula, Solidago, Helianthus and Conyza), they are accumulated as saponins. Oleanolic acid and ursolic acid are also present in many sunflowers. ${ }^{24}$

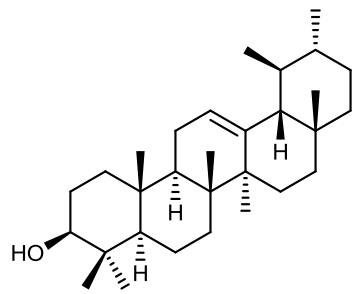

5

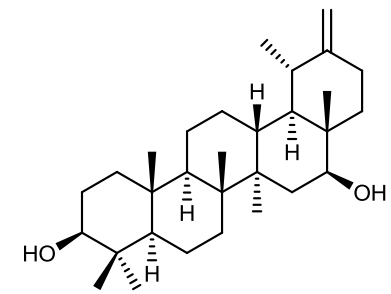

6

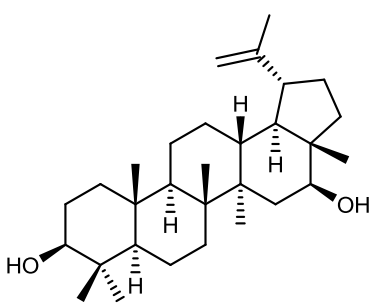

7

\section{Acetylenes}

Acetylenic natural products include fatty acid-derived compounds with unique carbon-carbon triple bond functionality. The compounds themselves tend to be unstable, succumbing to either oxidative, photolytic or pH-dependent decomposition. ${ }^{28}$ The Asteraceae acetylenes are found in the roots or leaves and possess antifungal, nemacidal and antibiotic activities. ${ }^{18,19}$

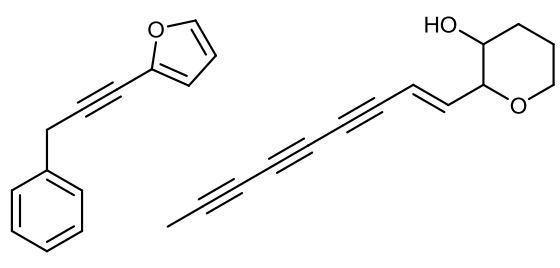

8

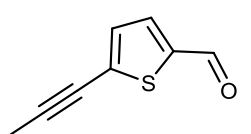

10

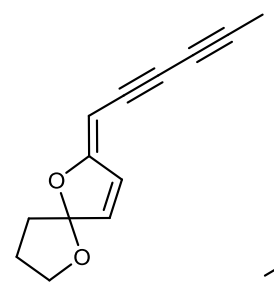

11

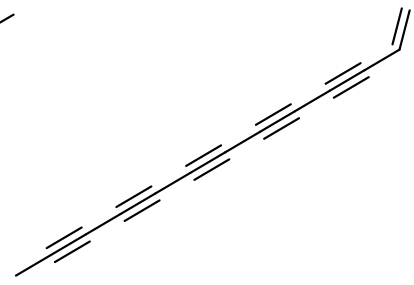

12

They are often characterized by the presence of cyclic, aromatic [e.g. carlina oxide (8)] or heterocyclic \{furanoid (e.g. 8), pyranoid [e.g. ichthyotereol (9)], thiophenic [e.g. junipal (10)], or spiroketal [e.g. E-spiroether (11)]\} end-groups. ${ }^{29}$ Aliphatic acetylenes are relatively rare; the most common is the $\mathrm{C}_{13}$ tridecapentaynene (12), but in the Astereae and Anthemideae tribes it is replaced by particular $\mathrm{C}_{10}$ and $\mathrm{C}_{17}$ acetylenes. ${ }^{18}$ 


\section{Flavonoids}

In sunflowers, the flavones apigenin (13) and luteolin (14) and the flavonols kaempferol (15) and quercetin (16) are ubiquitous, frequently in the form of glycosides and 6-hydroxy derivatives. Highly methoxylated flavonoids, based on apigenin (13), luteolin (14), kaempferol (15), quercetin (16) or quercetagetin (17), and chalcone glycosides as flower pigments are also often present. The flavonolignans [e.g. silibinin (18)] of Silybum marianum are unusual constituents in the family. ${ }^{24}$<smiles>[2H]c1c(O)cc2oc(-c3ccc(O)c(O)c3)cc(=O)c2c1O</smiles>

$\begin{array}{lllll} & R^{1} & R^{2} & R^{3} & R^{4} \\ 13 & H & H & H & H \\ 14 & H & H & H & \text { OH } \\ 15 & \text { OH } & \text { H } & H & H \\ 16 & \text { OH } & \text { H } & \text { H } & \text { OH } \\ 17 & \text { OH } & \text { OH } & \text { OH } & \text { H }\end{array}$<smiles>COc1cc(C2Oc3cc([C@@H]4Oc5cc(O)cc(O)c5C(=O)C4O)ccc3O[C@H]2CO)ccc1O</smiles>

18

\subsubsection{Pharmaceutical and economic importance}

Sunflowers are prominent among the plants utilized traditionally in all parts of the world. Over 260 species of the family are currently cultivated for other than ornamental purposes. ${ }^{18}$ In the European Pharmacopoeia, preparations of 16 species are official. ${ }^{30}$ Most of them are applied as antiphlogistic or spasmolytic (e.g. Matricaria recutita, Achillea millefolium, Arnica montana and Calendula officinalis) or as choleretic (e.g. Artemisia absinthium, Cynara scolymus and Taraxacum officinale) drugs. Some species have been used for more specific purposes, such as Echinacea purpurea (immunomodulatory), Silybum marianum (antihepatotoxic), Solidago virgaurea (diuretic) or Tanacetum parthenium (antimigraine). ${ }^{31}$

Certain plants have achieved both pharmaceutical and food industrial significance. Helianthus annuus is cultivated for its fatty oil, which is an extensively used industrial raw material. The oils of Carthamus tinctorius (safflower oil) and S. marianum (milk thistle oil) are valued for their highly unsaturated character and are therefore considered to be healthy salad oils. The roots of Helianthus tuberosus, Cichorium intybus and Taraxacum officinale are characterized by a great abundance of inulin, which is an important ingredient of diabetic foods and used as a prebiotic agent. The roots of these plants also provide a coffee substitute. Other plants (e.g. Artemisia spp. and Cnicus benedictus) are valued for their bitter or flavouring substances. ${ }^{32-35}$ The family provides raw material for numerous other industrial products, including soaps, detergents, varnishes, paints, cosmetics, rubber and perfumes. Tanacetum cinerariifolium, pyrethrum, yields the insecticidal monoterpenes called pyrethrins. $^{18}$ 
The Asteraceae contains several edible species consumed as leaf (Lactuca sativa, Cynara cardunculus, Cichorium endivia and C. intybus) or root (Scorzonera hispanica and Helianthus tuberosus) salads. Many plants are cultivated as ornamentals (e.g. Dahlia, Gerbera and Chrysanthemum spp.). ${ }^{18,36}$

A number of sunflowers are of negative economic or medical significance. For example, Parthenium hysterophorus and the pollen of Ambrosia artemisiifolia can cause allergic reactions, and many Senecio species are highly hepatotoxic. ${ }^{18}$

\subsection{LITERATURE DATA ON ASTERACEAE SPECIES WITH ANTICANCER PROPERTIES}

\subsubsection{Ethnopharmacological data}

Several members of the Asteraceae have traditionally been used worldwide for the treatment of different illnesses. As concerns anticancer applications, HARTWELL published a series of articles in Lloydia between 1967 and 1971 on plant species that had been reported to be used ethnomedically. 77-46 His monumental work was later extended by GRAHAM. ${ }^{8}$ These contributions summarized the data on about 300 species of Asteraceae. Many of these, chiefly plants from the genera Achillea, Anthemis, Arctium, Artemisia, Centaurea, Cichorium and Matricaria, are cited as remedies in European folk medicine, used against different types of cancers and tumours. For example, Artemisia campestris and $A$. vulgaris have been widely recommended against scirrhus and tumours of the uterus, spleen and stomach. In mediaeval Italy, the unguent of Arctium lappa was regarded as a medicine for tumours of the sinews. The salve of Anthemis nobilis (prepared with salt and heated in butter) was used to treat cancer in England. The juice of Cichorium intybus is currently utilized in Belgium against tumours and warts. ${ }^{7}$ In Hungary, the only Asteraceae plant applied to combat cancer was Matricaria recutita, as cited by VARRÓ and HARTWELL. ${ }^{7,47}$

\subsubsection{Experimental evidence of anticancer activity}

Asteraceae species that exhibit anticancer activity received attention in the late 1960s. In that period, species from the genera Artemisia, Elephantopus, Eupatorium, Helenium and Petasites were extensively investigated for their antiproliferative effects on different cancer cells of human (HEp-2, KB and W-18Va2) or animal (L-210, P-388 and W-256) origin. SLs with germacranolide, guaianolide, pseudoguaianolide, eudesmanolide or bakkenolide skeletons were demonstrated to be responsible for the antitumour action. ${ }^{26} \mathrm{~A}$ series of SLs were isolated from several Asteraceae species and tested on various tumour models. ${ }^{11-13,48-56}$ The evidence that accumulated from in vitro studies and in vivo animal experiments confirmed that SLs act as potent anticancer agents by disrupting the cell cycle, causing apoptosis in cancer cells, inhibiting angiogenesis and metastasis, and sensitizing tumour cells 
to chemotherapeutic drugs. The regulation of cellular signalling pathways such as in the NF-KB inflammatory system and the MAPK cascade, interaction with the SERCA pump and ROS generation, are important molecular mechanisms involved in these processes. ${ }^{15,16}$ The bioactivity of SLs is mediated chemically by alkylation of sulfhydryl groups through their $\alpha, \beta$-unsaturated carbonyl (an $\alpha$ methylene- $\gamma$-lactone, an $\alpha, \beta$-unsaturated cyclopentenone or a conjugated ester) or endoperoxide structures. ${ }^{57}$ Among the SLs, artemisinin (19), isolated in 1973 from Artemisia annua and currently used in antimalarial clinical practice, is an auspicious molecule in cancer drug discovery. Artemisinin and its derivatives artesunate (20) and artemether (21) are now undergoing clinical trials for laryngeal carcinomas, uveal melanoma, pituitary macroadenomas and breast, colorectal and nonsmall cell lung cancers. ${ }^{16,58}$ Parthenolide (22) from Tanacetum parthenium is another prominent sesquiterpenoid. Its analogue, dimethylaminoparthenolide (23), is at present in clinical phase I against certain types of blood and lymph node cancers. ${ }^{16}$ Helenanolides [e.g. helenalin (24)] isolated from Helenium and Inula species, xanthanolides [e.g. 8-epi-xanthatin (25)] from Xanthium italicum, and eupatoriopicrin (26) from Eupatorium cannabinum are also regarded as promising candidates for clinical trials. ${ }^{12,15}$

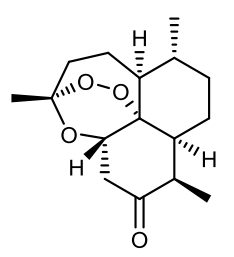

19

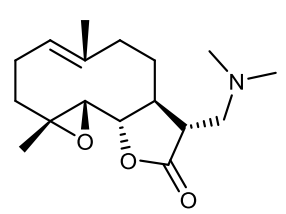

23

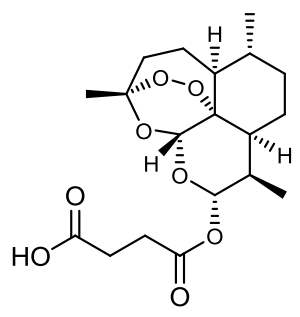

20

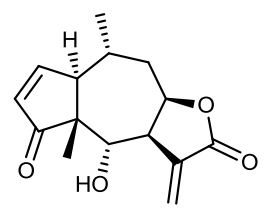

24

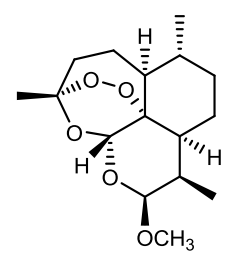

21<smiles>C=C1C(=O)OC2CC(C)C(/C=C/C(C)=O)=CCC12</smiles>

25<smiles>C=C1C(=O)OC2C1CCC(C)(C)C21CCCC(C)(C)O1</smiles>

22

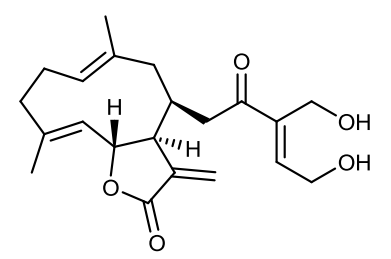

26

Bioassay-directed investigations of plant extracts that exert antitumour effects have frequently furnished flavonoids as active substances.,.$^{90,59,60}$ Since these chemicals occur ubiquitously in the plant kingdom, a large number of them have been evaluated for their anticancer properties. ${ }^{61-63}$ Apigenin (13), a representative cytotoxic flavone, exerts its anticancer effects by targeting multiple cellular pathways and is considered to be of great potential for development as a cancer- 
chemopreventive or chemotherapeutic agent. ${ }^{14}$ Silibinin (18), a flavonolignan of Silybum marianum, has been demonstrated to block all stages of carcinogenesis, initiation, promotion and progression, and its efficacy in human studies in patients with prostate cancer and colorectal carcinoma has also been proven. ${ }^{17}$

Furthermore, recent publications have evaluated other chemical structures as potential antiproliferative or cytotoxic constituents of some Asteraceae species. Acetylenic compounds in Echinacea pallida and Artemisia monosperma, ${ }^{60,64}$ triterpenes isolated from Calendula officinalis, Parthenium argentatum and Silphium radula, ${ }^{65-67}$ and lignans from Arctium lappa ${ }^{68}$ were found to exert marked antitumour activity in different test systems.

In spite of the considerable amount of experimental evidence indicative of the anticancer properties of Asteraceae species, comprehensive screening studies on the plants from this family are scarce. The systematic antitumour screening of the Brazilian Asteraceae by MoNKs et al. revealed 11 species with an in vitro antiproliferative effect. ${ }^{69}$ Additionally, a few data are available on some species assayed in different research projects that focused on medicinal plants used in Latin America or Africa. ${ }^{70-74}$ As regards the European species of Asteraceae, no antiproliferative screening studies have been published.

\subsection{ChARACTERIZATION OF PLANT SPECIES INVESTIGATED IN DETAIL}

\subsubsection{Conyza canadensis}

\section{Botany}

Conyza canadensis (L.) CRONQUIST (Canadian fleabane or horseweed; formerly Erigeron canadensis L.), a member of the tribe Astereae, is indigenous to North America, but is now found globally as an invasive weed on cultivated ground and waste places, and is also widely distributed in Hungary. It is an annual herb growing to $1.5 \mathrm{~m}$ and having a short taproot with laterals and several narrow, simple, alternate leaves. It has many capitula, less than $1 \mathrm{~cm}$ wide, in a long, paniculate inflorescence. There are numerous, small female florets, sitting in several rows, with a tubular-filiform corolla. Hermaphrodite florets are few, fertile and yellow. The achenes are flattened and covered with pappus. ${ }^{75,76}$

\section{Medicinal applications and anticancer properties}

The aerial parts of the plant have been used in different parts of the world to treat several ailments, most commonly diarrhoea and dysentery, and as a diuretic agent. In Chinese folk medicine, horseweed has also been applied as an antiphlogistic in the treatment of wounds, swellings and pain 
caused by arthritis. ${ }^{77,78}$ Moreover, a decoction of horseweed has traditionally been used to treat cancerous diseases in North America. ${ }^{7}$ No data are available on the experimental confirmation of its antitumour effect.

\section{Chemistry}

The phytochemical investigation of horseweed started with the studies by BOHLMANN in the 1960s. Six $\mathrm{C}_{10}$ acetylene derivatives [matricaria methyl ester isomers (27-29), E-lachnophyllum methyl ester (30) and $2 \gamma$-lactones $(31,32)]$ were reported as main constituents in the roots, as characteristic for the Conyza genus. 8Z-Matricaria- $\gamma$-lactone (31), an alkene and (-)- $\alpha$-trans-bergamotene were isolated from the above-ground parts. ${ }^{79}$

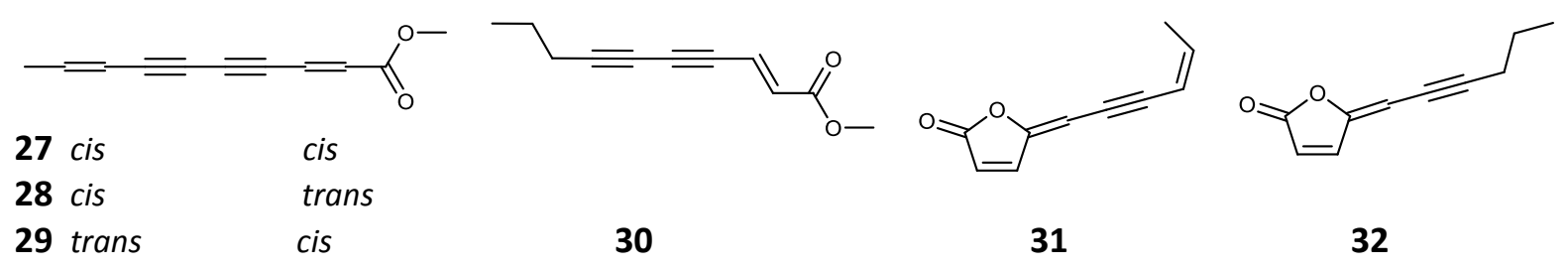

In the 1980s, the presence of sesquiterpene hydrocarbons [ $\gamma$-cadinene (33), b-santalene, 6 himachalene, cuparene and $\alpha$-curcumene] and flavonoids [apigenin (13), luteolin (14) and quercetin (16)] in the epigean parts was revealed by Czech and Polish groups. ${ }^{80,81}$

MUKHTAR et al. ${ }^{82,83}$ and XIE et al. ${ }^{84}$ later performed extensive chemical investigations of the whole plant, which led to the isolation of several secondary metabolites, including a new $C_{10}$ acetylene derivative, $8 R, 9 R$-dihydroxymatricaria methyl ester (34), and (+)-hydroxydihydroneocarvenol, sphingolipids [1,3,5-trihydroxy-2-hexadecanoylamino-9E-heptacosene $\quad$ (35), 1,3,5-trihydroxy-2hexadecanoylamino-6E,9E-heptacosdiene and their 1-O-B-D-glucopyranoside derivatives, and 1,3dihydroxy-2-hexanoylamino-4E-heptadecene], fatty acids [3-isopropenyl-6-oxoheptanoic acid, 9-hydroxy-10Z,12E-octadecenoic acid, and 9,12,13-trihydroxy-10Z-octadecenoic acid],

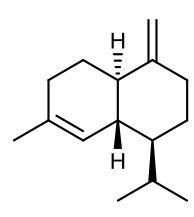

33

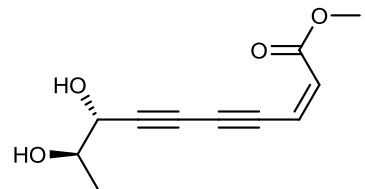

34

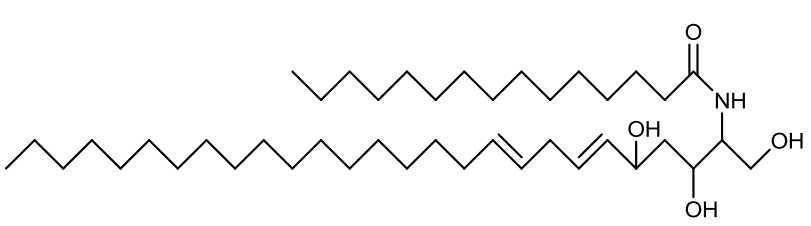

35

sterols, [spinasterol (36), stigmasterol (37), B-sitosterol (38) and its 3-O-B-D-glucopyranoside derivative], triterpenoids [36-hydroxyolean-12-en-28-oic acid (39), 36-erythrodiol (40), friedeline 
(41), epifriedelanol (42) and 36,166,206-trihydroxytaraxastane-3-O-palmitoyl ester], benzoic acid derivatives [p-hydroxybenzoic acid, 3,5-dihydroxybenzoic acid and 3,5-dimethoxybenzoic acid] and the 6 -carboline alkaloid harmine (43). Phenylpropanoyl 2,7-anhydro-3-deoxy-2-octulosonic acid derivatives were recently isolated. ${ }^{85}$

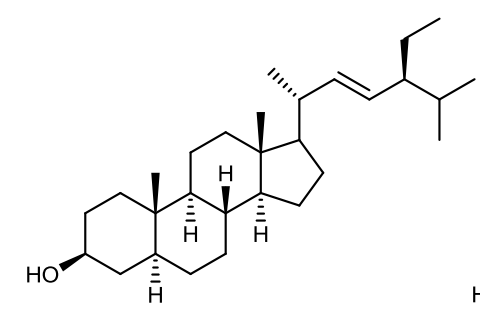

36

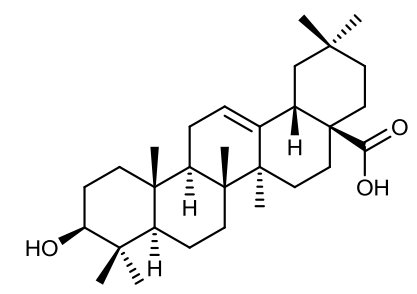

39

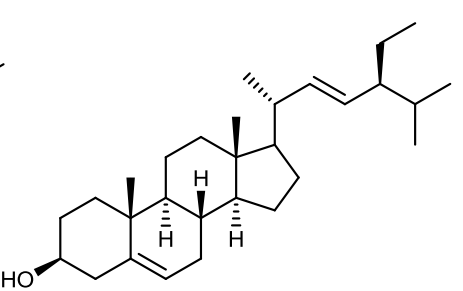

37

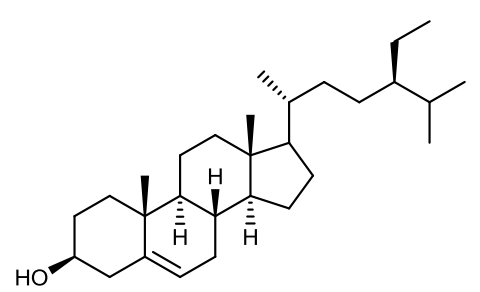

38

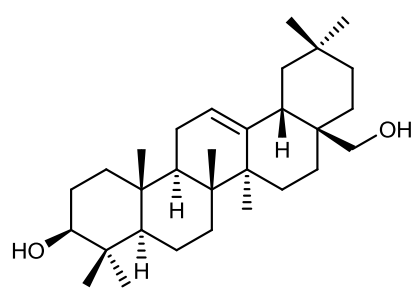

40

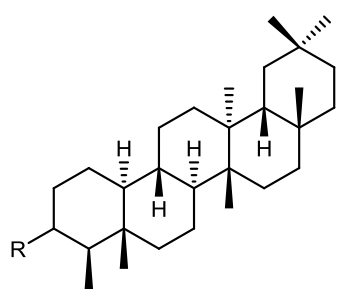

$41 \mathrm{R}:=\mathrm{O}$

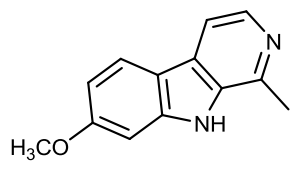

43

Analysis of the essential oil obtained from the herbs demonstrated the presence of several monoterpenes, sesquiterpenes and acetylenes, among which limonene predominated. ${ }^{86-88}$

\subsubsection{Achillea millefolium s.l.}

\section{Botany}

The genus Achillea (tribe Anthemideae), consisting of about 140 perennial herbs indigenous to the Northern hemisphere, can be divided into sections and groups (aggregates). The A. millefolium aggregate is cytologically a polyploid complex with species ranging from the diploid to the octoploid level. ${ }^{89}$ Within the group, 11 European species are described: A. roseo-alba EHREND., A. pratensis Saukel \& Länger, A. ceretanica Sennen, A. styriaca Saukel ined., A. millefolium subsp. sudetica Opiz, A. millefolium L., A. distans WaldSt. \& KIT. ex Willd., A. pannonica Scheele, A. setacea WAldSt. \& Kit., A. asplenifolia VENT.and A. collina J. BECKER ex REICHENB.; the latter 6 are also found in Hungary. Few representatives are known in North America (A. lanulosa NUTT. and A. borealis Bong.) and Central Asia [A. asiatica (L.) SERG.]. ${ }^{90,91}$ These species are scarcely separable on the basis of morphological, anatomical or caryological features; the high biodiversity and naturally occurring hybrids obviously 
complicate a clear definition and often permit only tentative species identification. Usually, all are included under the general term "yarrow" ${ }^{92,93}$ The herbs of the A. millefolium group are 8-120 cm in height, with stems erect or ascending, simple or branched above. The leaves are lanceolate and multiple-pinnate, alternate. The small flower heads are arranged in corymbs. The involucre is 3-4 $\mathrm{mm}$ in diameter, with the bracts in a few rows. The outer florets are ligulate, female, more or less 3dentate, patent or rarely short and erect. The ligules are 1-2 mm, white or pink to purplish-red. The inner florets are hermaphrodite, 5-lobed; the corolla-tube is compressed. The achenes are oblong or obovate; the pappus is absent. ${ }^{94}$

\section{Medicinal applications and anticancer properties}

Due to its antiphlogistic and spasmolytic effects, Achillea millefolium s.l. can be applied in the treatment of spasmodic dyspepsia and as a sitz-bath to cure gynaecologic inflammations. ${ }^{31}$

Achillea species have been widely applied in folk medicine for the treatment of different cancers, tumours and warts. In European and American countries, yarrow has been used in the form of different preparations (juice, ointment, oil, etc.) as traditional herbal medicine against cancer of the breast and liver, and hardness of the uterus. ${ }^{7}$ Experimentally, the anticancer activity of Achillea species has been proved in only a few instances. The cytotoxic or cytostatic effects of extracts of $A$. alexandri-regis, ${ }^{95}$ A. clavennae, ${ }^{96}$ A. ageratum ${ }^{97}$ and $A$. millefolium ${ }^{98}$ have been demonstrated against various malignant tumour cell lines, and guaianolides, 1,10-seco-guaiane sesquiterpenes and flavonols have been identified as responsible for the antitumour activity.

\section{Chemistry}

The distillation of a blue volatile oil by HoffMANn (1719) marked the beginning of the chemical analysis of yarrow. Since then, due to the blue colour of the oil and the pharmacological properties attributed to it, Achillea species have been extensively studied. ${ }^{99}$ Hence, the chemistry of yarrow is well documented.

The essential oil obtained from the epigean plant parts contains numerous mono-, sesqui- and diterpenoids and other compounds (e.g. phenylpropanoids, fatty acids and carotenoids). 1,8-Cineol, camphor, borneol, piperitone, limonene, $\alpha$ - and 6 -thujone, and isoartemisia ketone are the most frequently identified monoterpenes. The blue colour is due to the presence of azulene-like sesquiterpenes such as chamazulene (44) (0-40\%, depending on the origin), which are artefacts formed from azulenogenic guaianolides during steam distillation. Caryophyllene, $\alpha$-bisabolol and other sesquiterpenes may additionally be present in the oil. ${ }^{89,100}$ 


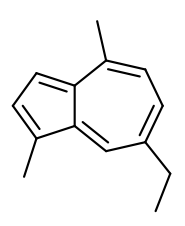

44

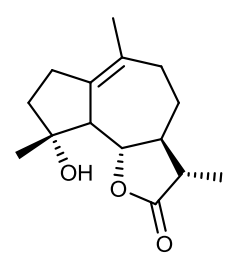

48
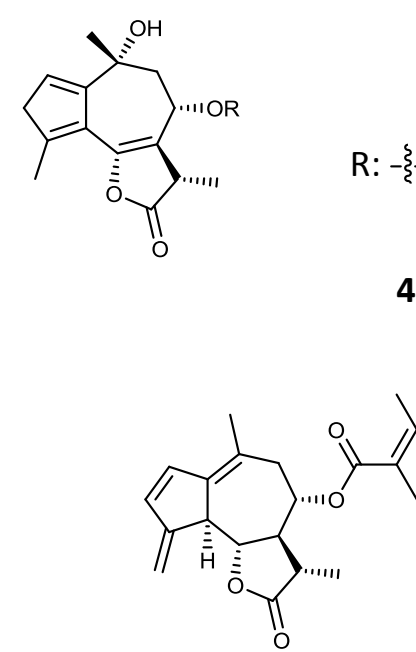

49<smiles>[R][Y4]([R])=C(C)/C(C)=C/C</smiles>

46

45
$\mathrm{R}:-\xi \mathcal{O}$

47<smiles>CC(=O)O[C@H]1C(C)=C2C=C[C@](C)(O)[C@@]2(C)[C@@H](OC(C)=O)C2[C@@H]1OC(=O)[C@@H]2C</smiles>

50<smiles>[R]C1C(=O)O[C@@H]2[C@@H]3C(C)=CC(=O)C3=C(C)C[C@H]([R])[C@H]12</smiles>

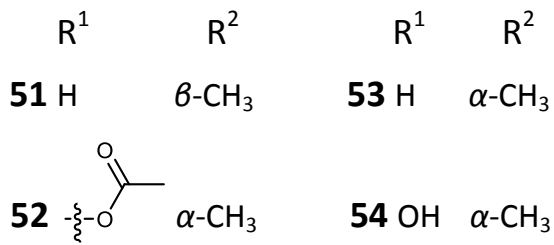<smiles></smiles>

55

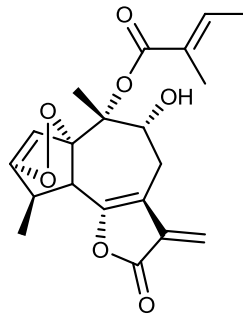

56

A wide spectrum of SLs are present in the $A$. millefolium group and the sesquiterpene profile can vary greatly between taxa. ${ }^{89}$ Proazulenes are mainly represented by 6,7-guaianolides including

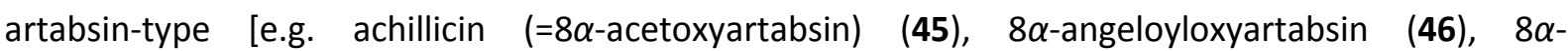
tigloyloxyartabsin (47)] and matricin-type compounds [e.g. 2,3-dihydrodesacetoxymatricin (48), 8desacetyl-8 $\alpha$-tigloylmatricin and 8-desacetyl-8 $\alpha$-tigloyl-4-epi-matricin]. ${ }^{100,101}$ In a recent publication, derivatives of tannunolide B, 6-epi-tannunolide B and 11-epi-tannunolide C [e.g. 8 $\alpha$-angeloyloxy-11epi-tannunolide (49)] were mentioned as azulenogenic guaianolides in A. asplenifolia. ${ }^{102}$ In certain taxa, 7,8-guaianolides [e.g. 46-hydroxy-6 $\alpha, 9 \alpha$-diacetoxy-5 $\alpha \mathrm{H}, 7 \alpha \mathrm{H}, 86 \mathrm{H}, 11 \alpha \mathrm{H}$-guai-1(10),2-dien-7,8olide (50)] have also been identified as proazulenes. ${ }^{92}$ Non-azulenogenic compounds include achillin (51), matricarin (52) and its derivatives [e.g. leucodin (=desacetoxymatricarin) (53), austricin (=desacetylmatricarin) (54)], 3-oxa-guaianolides [e.g. 3-oxa-achillicin (55)] and 1,4-endoperoxid derivatives [e.g. $\alpha$-peroxyachifolid (56)]..$^{92,100}$

Germacranolides may be represented by millefin (57), achillifolin (58), dihydroparthenolide and acetylbalchanolide $^{100}$ and by other recently isolated metabolites. ${ }^{102}$ Glaucolides [e.g. 13-hydroxy-36- 
isovaleroyloxygermacra-1(10)E,4E,7(11)-trien-12,6 $\alpha$-olide (59) and eudesmanolides [e.g. tauremisin (60)] are very rare components in A. millefolium s.l. ${ }^{89,102}$<smiles>C/C=C\C[C@H](OC(C)=O)[C@@H]1/C(=C/C)[C@H](OC(C)=O)CC1OC(C)=O</smiles>

57<smiles>C[C@H]1CCC2[C@H](OC(=O)[C@@H]2C)[C@H](O)[C@]1(C)O</smiles>

58

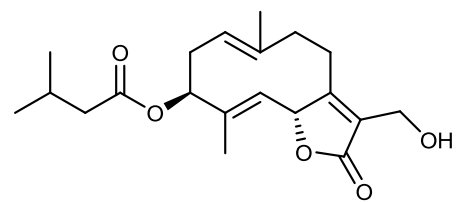

59

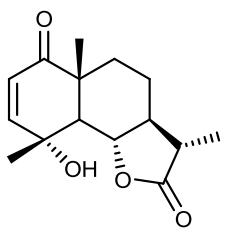

60

As concerns the flavonoids, predominantly the flavones apigenin (13) and luteolin (14) and their 7-glycosides, with lesser quantities of 5-hydroxy-3,6,7,4'-tetramethoxyflavone (61), artemetin (62), casticin (63), isorhamnetin and rutin are present in the A. millefolium group. ${ }^{103}$ For some species, the presence of centaureidin (64), acacetin (65) and diosmetin (66) has also been described. ${ }^{104,105}$

Yarrow contains alkaloids such as betonicine (67) and stachydrine (68) (pyrrolidines) and trigonelline (69) (a pyridine), and bases such as betaine and choline. Uncharacterized alkaloids isolated from yarrow include achiceine, achillein (a possible synonym for L-betonicine), which is stated to yield achilletine on alkaline hydrolysis, and moscatine/moschatine, reported to be an ill-defined glucoalkaloid. ${ }^{103}$ In the subterranean parts of the plants, polyacetylenes [e.g. ponticaepoxide (70)] and alkamides [e.g. deca-2E,4E,6Z-trienoic piperideide (71)] are accumulated. ${ }^{93,101}$

\begin{tabular}{|c|c|c|c|}
\hline $\mathrm{R}^{1}$ & $\mathrm{R}^{2}$ & $\mathrm{R}^{3}$ & $\mathrm{R}^{4}$ \\
\hline $61 \mathrm{OCH}_{3}$ & $\mathrm{OCH}_{3}$ & $\mathrm{CH}_{3}$ & $\mathrm{H}$ \\
\hline $62 \mathrm{OCH}_{3}$ & $\mathrm{OCH}_{3}$ & $\mathrm{CH}_{3}$ & $\mathrm{OCH}_{3}$ \\
\hline $63 \mathrm{OH}$ & $\mathrm{OCH}_{3}$ & $\mathrm{CH}_{3}$ & $\mathrm{OCH}_{3}$ \\
\hline
\end{tabular}

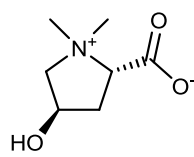

67

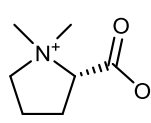

68<smiles>[R20]c1cc2oc(-c3cc([R20])c(OC)c([R])c3)c([R])c(=O)c2c(O)c1[R]</smiles>

$\begin{array}{lllll}\mathrm{R}^{1} & \mathrm{R}^{2} & \mathrm{R}^{3} & \mathrm{R}^{4} & \mathrm{R}^{5} \\ \mathbf{\mathrm { OCH } _ { 3 }} & \mathrm{OCH}_{3} & \mathrm{H} & \mathrm{OH} & \mathrm{H} \\ \mathrm{H} & \mathrm{H} & \mathrm{H} & \mathrm{H} & \mathrm{H} \\ \mathrm{H} & \mathrm{H} & \mathrm{H} & \mathrm{H} & \mathrm{OH}\end{array}$<smiles>C[n+]1cccc(C(=O)O)c1</smiles>

69

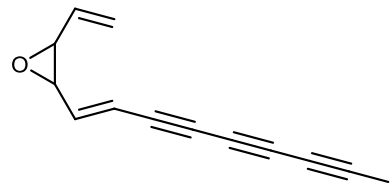

70

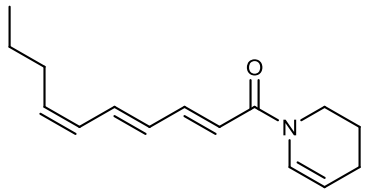

71

Additionally, amino acids, fatty acids, and ascorbic acid, caffeic acid, folic acid, salicylic acid and succinic acid have been described in yarrow. ${ }^{103}$ The occurrence of kaurane diterpenes, triterpenes, sterols and sugars is also mentioned in the literature. ${ }^{89}$ 


\section{MATERIALS AND METHODS}

\subsection{Plant material}

\subsubsection{Plants for antiproliferative screening}

Asteraceae species were collected between June and August 2004 from several regions of Hungary (the Southern Great Plain, the Central Great Plain and near Budaörs). Botanical identifications were performed by TAMÁS RÉDEI (MTA ÖBKI - Institute of Ecology and Botany of the Hungarian Academy of Sciences, Vácrátót). Samples of Artemisia asiatica, A. japonica and A. messerschmidtiana were supplied from cultivars at the MTA ÖBKI, Vácrátót. Matricaria chamomilla was from a commercial source, with characteristics meeting the requirements of Pharmacopoeia Hungarica, edition VII. Plants were separated into roots and different aerial parts (herbs or leaves, stems and flowers). The air-dried plant organs were comminuted and stored at room temperature until processing.

\subsubsection{Plants for activity-guided investigation}

The roots of Conyza canadensis (L.) CRONQUIST (formerly Erigeron canadensis L.) were collected in the Southern Great Plain (Hungary) in September 2004 and authenticated by TAMÁs RÉDEI (MTA ÖBKI, Vácrátót). A commercial sample of the dried and ground herbs of A. millefolium s.l. (Achilleae herba, Pharmacopoea Hungarica VII; GYNKI-216302077), purchased in 2005 from Rózsahegyi Kft., Erdőkertes, Hungary, was used for the phytochemical investigations. Plant materials were stored at room temperature until processing.

\subsection{TRIBAL DIVISION OF PLANTS FOR THE ASSESSMENT OF THE SCREENING STUDY}

The tested species were assorted into 6 tribes (Cynareae, Cichorieae, Astereae, Anthemideae, Inuleae and Heliantheae) of the Asteraceae, using the classification of JEFFREY. ${ }^{18}$

\subsection{EXTRACTION}

\subsubsection{Preparation of extracts for antiproliferative screening}

All extracts were prepared from $10 \mathrm{~g}$ of plant material comminuted with an electric grinder (Nileline DU-2021). Samples were extracted with $100 \mathrm{ml}$ of $\mathrm{MeOH}$ using a VWR ultrasonic bed (type USC500TH) at room temperature. After filtration, solvents were evaporated to dryness. The residues were dissolved in a mixture of $\mathrm{MeOH}-\mathrm{H}_{2} \mathrm{O}$ 1:1 (50 ml) and were subjected to solvent-solvent partitioning between $n$-hexane $(3 \times 50 \mathrm{ml})$ and $\mathrm{CHCl}_{3}(3 \times 50 \mathrm{ml})$. The $n$-hexane-soluble and the $\mathrm{CHCl}_{3}$ soluble fractions were evaporated to dryness to yield extracts marked with $A$ and $B$, respectively. After evaporation, the remnant aqueous methanolic phases gave extracts $C$. The residual plant 
materials were dried and extracted with $30 \mathrm{ml}$ of boiling $\mathrm{H}_{2} \mathrm{O}$ for 15 minutes, using a multiple water bath (type 1041, GFL). The filtered extracts were freeze-dried by means of a Hetosicc liophilizator (type CD 52, Heto Lab Equipment), affording extracts D.

\subsubsection{Extraction of plant materials for activity-guided investigation}

Extracts were concentrated under reduced pressure with a Büchi Rotavapor rotary evaporation system, immersed in a water bath not warmer than $40^{\circ} \mathrm{C}$.

\section{Conyza canadensis}

The air-dried roots were crushed with a Retsch grinder (type SM 100) to furnish $2.6 \mathrm{~kg}$ of plant material, which was percolated with $\mathrm{MeOH}(50 \mathrm{l})$ at room temperature. The extract was concentrated to $300 \mathrm{ml}$ and diluted with $300 \mathrm{ml}$ of $\mathrm{H}_{2} \mathrm{O}$, and the solution was extracted first with $n$ hexane $(5 \times 2 \mathrm{I})$ and subsequently with $\mathrm{CHCl}_{3}(7 \times 2 \mathrm{I})$.

\section{Achillea millefolium}

$5.0 \mathrm{~kg}$ of the raw material originating from a commercial sample was extracted by percolation with $\mathrm{MeOH}(100 \mathrm{l})$ at room temperature. The concentrated extract $(1800 \mathrm{ml})$ was diluted with $1800 \mathrm{ml}$ $\mathrm{H}_{2} \mathrm{O}$ and subjected to solvent-solvent partition between $n$-hexane $(10 \times 2 \mathrm{I})$ and $\mathrm{CHCl}_{3}(12 \times 2 \mathrm{I})$.

\subsection{PURIFICATION AND ISOLATION OF COMPOUNDS}

Fractions and isolates were evaporated under vacuum with a Büchi Rotavapor rotary evaporation system, immersed in a water bath not warmer than $40{ }^{\circ} \mathrm{C}$. Mobile phases in all types of chromatography are specified in terms of volume ratio, $\mathrm{v} / \mathrm{v}$.

4.4.1. Vacuum liquid chromatography (VLC) was carried out on $\mathrm{SiO}_{2}$ (silica gel $60 \mathrm{GF}_{254}, 15 \mu \mathrm{m}$, Merck 11677; VLC-1: 345 g, VLC-2: 66 g, VLC-3: 340 g, VLC-4: 97.5 g, VLC-5: 395 g, VLC-6: 140 g, VLC7: 86 g, VLC-8: 145 g, VLC-9: 135 g). Mobile phases:

VLC-1: $n$-hexane-EtOAc [98:2, 96:4, 94:6, 92:8, 9:1, 8:2, 6:4 and 3:7 $(1120 \mathrm{ml}, 800 \mathrm{ml}, 640 \mathrm{ml}$, $2000 \mathrm{ml}, 1200 \mathrm{ml}, 720 \mathrm{ml}, 480 \mathrm{ml}$ and $480 \mathrm{ml}$, respectively)] and EtOAc $(800 \mathrm{ml})$; volume of collected fractions: $80 \mathrm{ml}$.

VLC-2: $n$-hexane-acetone [96:4, 94:6, 92:8, 9:1 and 7:3 $(280 \mathrm{ml}, 370 \mathrm{ml}, 440 \mathrm{ml}, 390 \mathrm{ml}$ and $520 \mathrm{ml}$, respectively)]; volume of collected fractions: $10 \mathrm{ml}$.

VLC-3: $\mathrm{CH}_{2} \mathrm{Cl}_{2}-\mathrm{MeOH}$ [98:2, 96:4, 94:6, 9:1 and 8:2 $(800 \mathrm{ml}, 900 \mathrm{ml}, 1400 \mathrm{ml}, 600 \mathrm{ml}$ and $500 \mathrm{ml}$, respectively)]; volume of collected fractions: $100 \mathrm{ml}$.

VLC-4: toluene-EtOAc-acetone [6:3:1, 5:5:1 and 4:5:2 (350 ml, $150 \mathrm{ml}$ and $300 \mathrm{ml}$, respectively)]; volume of collected fractions: $25 \mathrm{ml}$. 
VLC-5: $n$-hexane-EtOAc [7:3, 1:1 and $3: 7(700 \mathrm{ml}, 1500 \mathrm{ml}$ and $1100 \mathrm{ml}$, respectively)], EtOAc $(1500 \mathrm{ml})$, EtOAc-MeOH [8:2 and 3:2 (1000 $\mathrm{ml}$ and $900 \mathrm{ml}$, respectively)] and $\mathrm{MeOH}(300 \mathrm{ml})$; volume of collected fractions: $100 \mathrm{ml}$.

VLC-6: toluene-acetone [9:1, 8:2, 7:3, 6:4, 1:1 and 3:7 $(100 \mathrm{ml}, 120 \mathrm{ml}, 360 \mathrm{ml}, 280 \mathrm{ml}, 300 \mathrm{ml}$ and $320 \mathrm{ml}$, respectively)] and acetone $(180 \mathrm{ml})$; volume of collected fractions: $20 \mathrm{ml}$.

VLC-7: toluene-acetone [9:1 (50 ml), 8:2, 7:3, 6:4, 1:1 and 3:7 (100 $\mathrm{ml}$ each)] and acetone $(180 \mathrm{ml})$; volume of collected fractions: $5 \mathrm{ml}$.

VLC-8: toluene-acetone (7:3, 6:4, 1:1, 4:6 and 2:8) and acetone (100 ml each); volume of collected fractions: $10 \mathrm{ml}$, excluding fractions $16-55$ (5 ml each).

VLC-9: $n$-hexane-acetone [6:4 $(160 \mathrm{ml}), 1: 1,4: 6$ and 3:7 $(80 \mathrm{ml}$ each $)]$ and acetone $(250 \mathrm{ml})$; volume of collected fractions: $10 \mathrm{ml}$.

4.4.2. Rotation planar chromatography (RPC) was performed using a Chromatotron instrument (model 8924, Harrison Research) on manually coated $\mathrm{SiO}_{2}$ (silica gel $60 \mathrm{GF}_{254}$, Merck 7730; RPC-1RPC-6 and RPC-8-RPC-17) or $\mathrm{Al}_{2} \mathrm{O}_{3}$ (aluminium oxide G, type E, Merck 1090; RPC-7) plates of 1 (RPC-2, RPC-8 and RPC-13), 2 (RPC-1, RPC-3, RPC-5, RPC-7, RPC-11, RPC-12, RPC-14, RPC-15 and RPC-17), 4 (RPC-4, RPC-6 and RPC-16) or 8 (RPC-9 and RPC-10) mm thickness, at a flow rate of 3, 4, 10 or $12 \mathrm{ml} / \mathrm{min}$, respectively. Mobile phases:

RPC-1: $n$-hexane-acetone [99:1, 19:1 and 4:1 (100 ml, $50 \mathrm{ml}$ and $100 \mathrm{ml}$, respectively)]; volume of collected fractions: $10 \mathrm{ml}$.

RPC-2: cyclohexane-EtOAc 9:1 (100 ml); volume of collected fractions: the first fraction: $10 \mathrm{ml}$, further fractions: $2 \mathrm{ml}$ each.

RPC-3: $n$-hexane-acetone 9:1 (150 ml); volume of collected fractions: $5 \mathrm{ml}$.

RPC-4: toluene- $\mathrm{CH}_{2} \mathrm{Cl}_{2}$ [7:3, 1:1 and $3: 7(210 \mathrm{ml}, 150 \mathrm{ml}$ and $180 \mathrm{ml}$, respectively)]; volume of collected fractions: $30 \mathrm{ml}$.

RPC-5: petroleum ether $-\mathrm{CH}_{2} \mathrm{Cl}_{2}$ 1:1 (150 ml); volume of collected fractions: $5 \mathrm{ml}$.

RPC-6: $n$-hexane-EtOAc [8:2, 7:3 and 6:4 $(150 \mathrm{ml}, 100 \mathrm{ml}$ and $150 \mathrm{ml}$, respectively)]; volume of collected fractions: $25 \mathrm{ml}$.

RPC-7: cyclohexane- $\mathrm{CH}_{2} \mathrm{Cl}_{2}-\mathrm{MeOH}$ [30:10:1, 20:20:1 and 5:15:1 $(40 \mathrm{ml}, 120 \mathrm{ml}$ and $150 \mathrm{ml}$, respectively)]; volume of collected fractions: $10 \mathrm{ml}$.

RPC-8: $n$-hexane-EtOAc 3:2 (100 ml); volume of collected fractions: $2 \mathrm{ml}$.

RPC-9: $n$-hexane-EtOAc-MeOH [10:8:1, 5:4:1 and $3: 7: 2 \quad(300 \mathrm{ml}, 400 \mathrm{ml}$ and $500 \mathrm{ml}$, respectively)]; volume of collected fractions: $50 \mathrm{ml}$. 
RPC-10: $n$-hexane-EtOAc-MeOH [5:4:1, 3:7:2 and 1:8:3 $(520 \mathrm{ml}, 240 \mathrm{ml}$ and $120 \mathrm{ml}$, respectively)] and EtOAc-MeOH 1:1 (480 ml); volume of collected fractions: $40 \mathrm{ml}$.

RPC-11: $n$-hexane-acetone-MeOH 6:14:5 (250 ml); volume of collected fractions: $10 \mathrm{ml}$.

RPC-12: cyclohexane- $\mathrm{CH}_{2} \mathrm{Cl}_{2}-\mathrm{MeOH}$ [7:13:1, 5:15:1 and 3:17:2 $(70 \mathrm{ml}, 105 \mathrm{ml}$ and $140 \mathrm{ml}$, respectively)]; volume of collected fractions: $7 \mathrm{ml}$.

RP-13: cyclohexane- $\mathrm{CH}_{2} \mathrm{Cl}_{2}-\mathrm{MeOH}$ 20:20:1 (150 ml); volume of collected fractions: $5 \mathrm{ml}$.

RPC-14: $\mathrm{CHCl}_{3}-\mathrm{MeOH}$ 99:1 (400 ml); volume of collected fractions: $10 \mathrm{ml}$.

RPC-15: cyclohexane- $\mathrm{CH}_{2} \mathrm{Cl}_{2}-\mathrm{MeOH}$ [14:26:1, 7:13:1 (100 $\mathrm{ml}$ each) and 5:15:1 (300 ml)]; volume of collected fractions: $10 \mathrm{ml}$.

RPC-16: cyclohexane- $\mathrm{CH}_{2} \mathrm{Cl}_{2}-\mathrm{MeOH}$ [3:17:2 and 1:19:3 (100 ml each)] and $\mathrm{CH}_{2} \mathrm{Cl}_{2}-\mathrm{MeOH}$ [3:1 and 1:1 (100 ml each)]; volume of collected fractions: $10 \mathrm{ml}$.

RPC-17: acetone-MeOH [1:1, 3:7 and 1:9 $(200 \mathrm{ml}, 100 \mathrm{ml}$ and $140 \mathrm{ml})]$; volume of collected fractions: $20 \mathrm{ml}$.

4.4.3. Preparative layer chromatography (PLC) was performed on $\mathrm{SiO}_{2}$ plates $(20 \times 20 \mathrm{~cm}$, silica gel $60 \mathrm{~F}_{254}$, Merck 5715). Separation was monitored by spraying the border of the plates with concentrated $\mathrm{H}_{2} \mathrm{SO}_{4}$ (PLC I) or in UV light at 254 and $366 \mathrm{~nm}$ (PLC II-IV). Compounds were eluted from the scraped adsorbent with $\mathrm{CHCl}_{3}$ (PLC I-III) or acetone-MeOH 1:1 (PLC IV). Mobile phases:

PLC I: $n$-hexane-EtOAc 13:5

PLC II: cyclohexane- $\mathrm{CH}_{2} \mathrm{Cl}_{2}-\mathrm{MeOH}$ 10:30:1

PLC II: cyclohexane- $\mathrm{CH}_{2} \mathrm{Cl}_{2}-\mathrm{EtOAc}-\mathrm{MeOH}$ 7:6:8:1

PLC IV: $\mathrm{CHCl}_{3}-\mathrm{MeOH}$ 9:1

4.4.4. Gel filtration (GF) was performed on Sephadex LH-20 (25-100 $\mu \mathrm{m}$, Pharmacia Fine Chemicals, $10 \mathrm{~g})$. Mobile phase: $\mathrm{MeOH}(80 \mathrm{ml})$; volume of collected fractions: the first fraction: $20 \mathrm{ml}$, further fractions: $2 \mathrm{ml}$ each.

4.4.5. High-performance liquid chromatography (HPLC) was carried out on a Waters Pump 600 instrument equipped with a Waters 2998 photodiode array (PDA) detector and a LiChrospher 100 RP$18\left(10 \mu \mathrm{m}, 250 \times 4 \mathrm{~mm}\right.$, Merck) reversed-phase column. A mobile phase containing $\mathrm{MeOH}-\mathrm{H}_{2} \mathrm{O}$ 3:2 was applied at a flow rate of $0.4 \mathrm{ml} / \mathrm{min}$; the separation was monitored at $220 \mathrm{~nm}$.

\subsection{Characterization AND StRUCtURE elUcidation OF COMPOUNDS}

Nuclear magnetic resonance (NMR) spectroscopy was carried out on a Bruker Avance DRX spectrometer at $500 \mathrm{MHz}\left({ }^{1} \mathrm{H}\right)$ or $125 \mathrm{MHz}\left({ }^{13} \mathrm{C}\right)$, with $\mathrm{CDCl}_{3}$ as solvent. The signals of the deuterated 
solvent were taken as reference. Two-dimensional experiments $\left({ }^{1} \mathrm{H}, \mathrm{H}\right.$ COSY, NOESY, HSQC and $\mathrm{HMBC}$ ) were set up and processed with standard Bruker software. Electrospray ionization mass spectrometry (ESIMS) measurements were performed on a Finnigan TSQ 7000 tandem mass spectrometer (Finnigan MAT, San Jose, CA) equipped with a Finnigan electrospray ion source. Highresolution electron ionization mass spectrometry (HREIMS) was carried out on a Finnigan MAT $95 \mathrm{~S}$ and a VG ZAB SEQ hybrid mass spectrometer equipped with a CS SIMS ion source. Ultraviolet (UV) spectra were obtained from the PDA-HPLC investigations. Optical rotation values were determined in $\mathrm{CHCl}_{3}$ at room temperature by using a Perkin-Elmer 341 polarimeter.

\subsection{BIOASSAYS}

The pharmacological tests were carried out by the staff of the Department of Pharmacodynamics and Biopharmacy. In the course of the screening studies and the pharmacological assay of compounds from A. millefolium, antiproliferative effects were measured on 3 human cell lines [HeLa (cervix adenocarcinoma, ATCC: CCL-2), MCF-7 (breast adenocarcinoma, ATCC: HTB-22) and A-431 (skin epidermoid carcinoma, ATCC: CRL-1555)] with the MTT assay. ${ }^{106}$ Apart from the above-mentioned cell lines, MRC-5 (non-cancerous human foetal lung fibroblast, ATCC: CCL-171) cells were also applied to study the compounds of $C$. canadensis. A limited number of the cells (5000/well) were seeded onto a 96-well microplate and became attached to the bottom of the well overnight. On the second day of the procedure, the original medium was removed and $200 \mu \mathrm{l}$ of new medium containing the test substances was added. After an incubation period of $72 \mathrm{~h}$, the living cells were assayed by the addition of $20 \mu \mathrm{l}$ of MTT solution at $5 \mathrm{mg} / \mathrm{ml}$. MTT was converted by intact mitochondrial reductase and precipitated as blue crystals during a $4 \mathrm{~h}$ contact period. The medium was then removed and the precipitated crystals were dissolved in $100 \mu$ l of dimethyl sulfoxide (DMSO) during a 60 min period of shaking. The reduced MTT was assayed at $545 \mathrm{~nm}$, using a microplate reader, wells with untreated cells being taken as the control. All in vitro experiments were carried out on 2 microplates with at least 5 parallel wells. Stock solutions of $10 \mathrm{mg} / \mathrm{ml}$ of the tested materials were prepared with DMSO. The highest DMSO concentration (0.3\%) of the medium did not have any significant effect on cell proliferation. The dose-response curves of the compounds were fitted by means of the computer program GraphPad Prism 4.0 (GraphPad Software, San Diego, CA, USA), and IC 50 values were calculated. Doxorubicin [ $\mathrm{IC}_{50}$ values $(\mu \mathrm{g} / \mathrm{ml}): 0.09$ (HeLa), 0.16 (MCF-7), 0.09 (A-431) and 0.29 (MRC-5)] and cisplatin [IC 50 values $(\mu \mathrm{g} / \mathrm{ml}): 3.73$ (HeLa), 2.89 (MCF-7), 0.85 (A-431) and 1.23 (MRC-5)] were used as positive controls. 


\section{RESULTS}

\subsection{SCREENING OF THE HUNGARIAN ASTERACEAE FOR ANTITUMOUR EFFECTS}

In the course of this screening programme for antiproliferative substances in the Asteraceae family, 50 species collected in Hungary (see section 4.1.1) were tested in vitro for their antitumour effects. A minority of the tested species (Artemisia asiatica, A. japonica and A. messerschmidtiana) are not native to Hungary and were therefore supplied from cultivars. A total of 420 extracts, obtained with $n$-hexane (A), $\mathrm{CHCl}_{3}(B)$, aqueous $\mathrm{MeOH}(\mathrm{C})$ and $\mathrm{H}_{2} \mathrm{O}(\mathrm{D})$ from different plant organs, were evaluated at a concentration of $10 \mu \mathrm{g} / \mathrm{ml}$ against HeLa, A-431 and MCF-7 cells, using the MTT assay (see sections 4.3.1 and 4.6). Data resulting from the bioassays are listed in Annex 1.

In summary, 41 extracts exerted $\geq 50 \%$ inhibition of the proliferation of at least one of the cell lines. Further, 92 samples demonstrated a weaker, $25-49.99 \%$ inhibition, while 287 of the extracts were shown to have no inhibitory potency on the investigated cells. Extracts with $\geq 50 \%$ antiproliferative activity on any cell line were selected for additional measurements in the concentration range of $0.3-30 \mu \mathrm{g} / \mathrm{ml}$. Complete dose-response curves were generated and $\mathrm{IC}_{50}$ values were determined for these active samples, as presented in Table 1.

Table 1. Antiproliferative $\mathrm{IC}_{50}$ values $(\mu \mathrm{g} / \mathrm{ml})$ of the selected plant extracts

\begin{tabular}{|c|c|c|c|c|c|}
\hline \multirow{2}{*}{ Species in tribes } & \multirow{2}{*}{ Plant parts } & \multirow{2}{*}{ Solvents } & \multicolumn{3}{|c|}{${ }^{\prime} C_{50}(\mu \mathrm{g} / \mathrm{ml})$} \\
\hline & & & HeLa & MCF-7 & A-431 \\
\hline \multicolumn{6}{|l|}{ CYNAREAE } \\
\hline Arctium lappa L. & leaves & $\mathrm{B}$ & 4.55 & 3.20 & 2,76 \\
\hline Arctium tomentosum MILL. & leaves & $\mathrm{B}$ & 7.76 & 4.08 & 4.55 \\
\hline Centaurea biebersteinii D. C. & herbs & $\mathrm{B}$ & 15.36 & 5.72 & 6.94 \\
\hline \multirow{5}{*}{ Centaurea jacea L. } & flowers/fruits & $\mathrm{B}$ & 4.36 & 10.10 & 11.35 \\
\hline & leaves & $\mathrm{B}$ & 6.27 & 12.19 & 11.77 \\
\hline & \multirow{3}{*}{ roots } & A & 8.82 & 17.74 & $>30$ \\
\hline & & $\mathrm{B}$ & 0.37 & 1.68 & 8.48 \\
\hline & & $\mathrm{C}$ & 5.71 & $>30$ & $>30$ \\
\hline Centaurea spinulosa RocHEL & herbs & $\mathrm{B}$ & 20.17 & 6.39 & 14.57 \\
\hline Cirsium vulgare (Savi) TEN. & flowers/fruits & $\mathrm{B}$ & $>30$ & $>30$ & 20.45 \\
\hline \multirow{2}{*}{ Onopordum acanthium L. } & leaves & $\mathrm{B}$ & 6.53 & 6.39 & 4.54 \\
\hline & roots & $\mathrm{B}$ & 6.11 & 4.39 & 10.32 \\
\hline \multicolumn{6}{|l|}{ CICHORIEAE syn. LACTUCEAE } \\
\hline Cichorium intybus L. & leaves & $\mathrm{B}$ & 12.52 & 6.92 & 9.65 \\
\hline \multirow{2}{*}{ Lactuca viminea J. PRESL \& C. PRESL } & \multirow{2}{*}{ roots } & A & 3.96 & $>30$ & 7.18 \\
\hline & & B & 10.62 & 20.93 & 6.06 \\
\hline Scorzonera austriaca WILLD. & roots & $\mathrm{B}$ & 6.42 & 5.52 & 4.71 \\
\hline \multicolumn{6}{|l|}{ ASTEREAE } \\
\hline Conyza canadensis (L.) CRONQ. & herbs & A & 17.4 & 7.93 & 11.6 \\
\hline
\end{tabular}


Table 1. (continued)

\begin{tabular}{|c|c|c|c|c|c|}
\hline Table 1. (continued) & & & HeLa & MCF-7 & A-431 \\
\hline \multirow{2}{*}{ Conyza canadensis (L.) CRONQ. } & herbs & $\mathrm{B}$ & 18.72 & 15.8 & 21.46 \\
\hline & roots & A & 6.47 & 3.32 & 9.47 \\
\hline \multirow{2}{*}{ Erigeron annuus PERS. } & \multirow{2}{*}{ roots } & A & 12.45 & 6.43 & 20.12 \\
\hline & & $\mathrm{B}$ & 12.94 & 9.17 & 13.96 \\
\hline \multicolumn{6}{|l|}{ ANTHEMIDEAE } \\
\hline \multirow{3}{*}{ Achillea collina J. BECKER ex REICHENB. } & flowers & $\mathrm{B}$ & 2.89 & $>30$ & 17.49 \\
\hline & leaves & $\mathrm{B}$ & 2.02 & 8.51 & $>30$ \\
\hline & herbs & $\mathrm{B}$ & 1.74 & $>30$ & 13.68 \\
\hline Anthemis ruthenica M. BIEB. & herbs & $\mathrm{B}$ & 6.75 & 7.34 & 7.11 \\
\hline \multirow{2}{*}{ Artemisia asiatica NAKAI EX PAMP. } & flowers & $\mathrm{B}$ & 5.99 & 2.85 & 4.19 \\
\hline & leaves & $\mathrm{B}$ & 10.42 & 10.45 & 4.96 \\
\hline \multirow{2}{*}{ Artemisia japonica THUNB. } & leaves & $\mathrm{B}$ & 9.72 & 6.43 & 7.95 \\
\hline & flowers & $\mathrm{B}$ & 6.89 & 3.01 & 4.88 \\
\hline \multicolumn{6}{|l|}{ INULEAE } \\
\hline Inula ensifolia $\mathrm{L}$. & fruits/flowers & $\mathrm{B}$ & 2.68 & $>30$ & 17.88 \\
\hline \multirow{2}{*}{ Telekia speciosa BAUMG. } & leaves & $\mathrm{B}$ & 4.29 & 5.22 & 2.93 \\
\hline & flowers & $\mathrm{B}$ & 8.55 & 6.78 & 4.99 \\
\hline \multicolumn{6}{|l|}{ HELIANTHEAE } \\
\hline \multirow{2}{*}{ Ambrosia artemisiifolia L. } & leaves & $\mathrm{B}$ & 19.82 & 10.24 & 11.12 \\
\hline & roots & $A$ & $>30$ & $>30$ & 8.55 \\
\hline Helianthus annuus L. & roots & $\mathrm{B}$ & 3.51 & 3.36 & 4.19 \\
\hline \multirow{6}{*}{ Xanthium italicum MORETTI } & \multirow{3}{*}{ buds/flowers } & A & 15.0 & 11.14 & 6.67 \\
\hline & & $\mathrm{B}$ & 2.78 & 2.69 & 0.74 \\
\hline & & $\mathrm{C}$ & 13.55 & 9.96 & 7.98 \\
\hline & leaves & $\mathrm{B}$ & 2.86 & 2.24 & 0.71 \\
\hline & \multirow{2}{*}{ roots } & A & 10.60 & 9.59 & 9.83 \\
\hline & & $B$ & 7.75 & 4.55 & 5.04 \\
\hline
\end{tabular}

In most cases, the selected extracts originated from the aerial plant parts (66\%). Mainly fractions B (76\% of the selected extracts), containing $\mathrm{CHCl}_{3}$-soluble lipophilic constituents, were found to be active. In some cases, the active compounds were accumulated in the $n$-hexane-soluble extracts (fractions A), such as the herb and root extracts of Conyza canadensis, the flower and root extracts of Xanthium italicum and the root extracts of Erigeron annuus, Ambrosia artemisiifolia, Centaurea jacea and Lactuca viminea. As concerns the aqueous $\mathrm{MeOH}$ fractions (C), only the flower extract of $X$. italicum and the root extract of $C$. jacea were effective. All of the aqueous extracts (fractions D) were found to be ineffective on the investigated cell lines.

Several extracts from the species of the tribe Cynareae, including plants of the genera Arctium, Centaurea, Cirsium and Onopordum, exhibited considerable $\mathrm{IC}_{50}$ values. The $\mathrm{CHCl}_{3}$ extract from the roots of $C$. jacea was the most potent sample in the whole screen, with an $I C_{50}$ value of $0.37 \mu \mathrm{g} / \mathrm{ml}$ on HeLa cells. Interestingly, all the fractions of the $\mathrm{MeOH}$ root extracts $(\mathrm{A}, \mathrm{B}$ and $\mathrm{C})$ of this plant were found to be active. Moreover, the $\mathrm{CHCl}_{3}$ extracts prepared from its other organs (flowers, fruits and 
leaves) were also effective. Similarly, in the case of Onopordum acanthium, both the root and the leaf extracts demonstrated a pronounced antitumour effect.

In the tribe Cichorieae, only 3 species (Cichorium intybus, Lactuca viminea and Scorzonera austriaca) of the several investigated plants proved to be active.

For the Astereae plants (Conyza canadensis and Erigeron annuus), the MCF-7 cells seemed to be more sensitive than the other 2 cell lines and the root extracts proved to be more effective than those from the aerial parts. The most potent extract was that obtained with $n$-hexane from the roots of $C$. canadensis (IC $50.32 \mu \mathrm{g} / \mathrm{ml}$ on MCF-7).

As concerns the tribe Anthemideae, high activities were detected for the $\mathrm{CHCl}_{3}$ extracts of Achillea collina, Anthemis ruthenica, Artemisia asiatica and A. japonica. Characteristically, these active fractions originated from the aerial plant parts. Among the investigated Artemisia species, the plants native to Hungary were found to be ineffective, in contrast with those native to Asia.

As regards the Inuleae species, Telekia speciosa proved to have marked efficacy on MCF-7 and A431, while Inula ensifolia was active on HeLa. It should be noted that the latter is the only plant in the screen for which only the reproductive organs were found to be effective.

In the tribe Heliantheae, the $\mathrm{CHCl}_{3}$ extracts of Xanthium italicum and Helianthus annuus proved to be markedly potent samples with $\mathrm{IC}_{50}$ values of $<5 \mu \mathrm{g} / \mathrm{ml}$ on all cell lines. $X$. italicum was a noteworthy plant as all of its investigated organs were highly effective. Pronounced antiproliferative activities were also recorded for Ambrosia artemisiifolia.

Taken together, the extracts causing $\geq 50 \%$ inhibition of proliferation represented 21 species of the 50 investigated plants. For 22 species, a moderate (25-49.99\%) cell growth inhibition was detected, while 7 plants were found to have no antitumour property in our study.

\subsection{ANTIPROLIFERATIVE EFFECTS OF PLANTS SELECTED FOR BIOACTIVITY-GUIDED INVESTIGATIONS}

On the basis of the results of the preliminary screening, Conyza canadensis and Achillea collina were chosen for more detailed phytochemical studies, with the aim of identification of their antitumour constituents. The screening results of these species demonstrated that the lipophilic extracts ( $A$ and $B$ ) of the herbs of $C$. canadensis were effective on MCF-7 cells $(58-60 \%$ at $10 \mu \mathrm{g} / \mathrm{ml})$; only weak activities (27-31\%) were detected on A-431 cells, and no effects on HeLa, as illustrated in Figure 3. In contrast, the lipophilic extracts of the roots inhibited the proliferation of all the tested cell lines: the $n$-hexane-soluble fractions displayed high activities (62-71\%), and the $\mathrm{CHCl}_{3}$-soluble fractions induced a moderate inhibition of proliferation (39-48\%). The extracts containing polar components 
( $C$ and $D$ ) and all of the flower extracts were ineffective in the screening study. In view of these results, lipophilic extracts of horseweed roots were selected for activity-guided investigation.
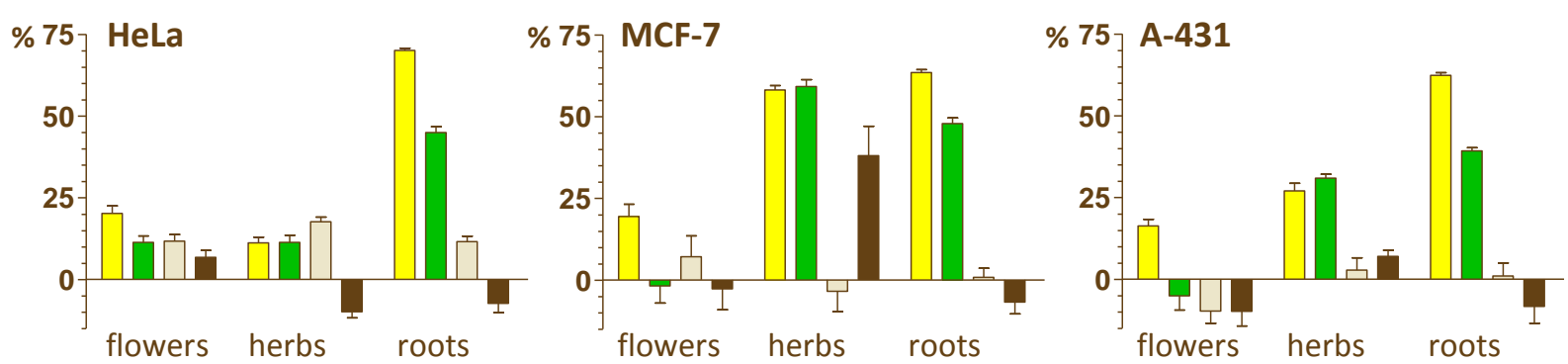

Figure 3. Antiproliferative activity of extracts of $C$. canadensis at $10 \mu \mathrm{g} / \mathrm{ml}$ (inhibition of proliferation, \%)

$\square n$-hexane fractions (A) $\square \mathrm{CHCl}_{3}$ fractions (B) $\square 50 \% \mathrm{MeOH}$ fractions (C) $\square \mathrm{H}_{2} \mathrm{O}$ fractions (D)

In the course of the screening of Achillea collina, it was observed that the aerial parts (flowers, leaves and herbs) displayed a marked antiproliferative effect, while the root extracts were moderately active (Figure 4). As concerns the aerial organs, the active compounds accumulated in the $\mathrm{CHCl}_{3}$-soluble fractions: the flower and leaf extracts were effective on HeLa cells $(82.5 \%$ and $82.8 \%$ inhibition, respectively) and the $\mathrm{CHCl}_{3}$ fraction of the herb extract proved to be active on both HeLa and MCF-7 (88.9\% and 53.9\%, respectively). Among the root extracts, only moderate activities were detected for the $n$-hexane-soluble fraction on HeLa (40.3\%) and for the $\mathrm{CHCl}_{3}$-soluble fraction on MCF-7 (35.2\%). The water-soluble extracts were found to be ineffective for all plant parts. In consequence of its outstanding biological activity, the $\mathrm{CHCl}_{3}$ fraction of the herb extract was selected for further analysis.

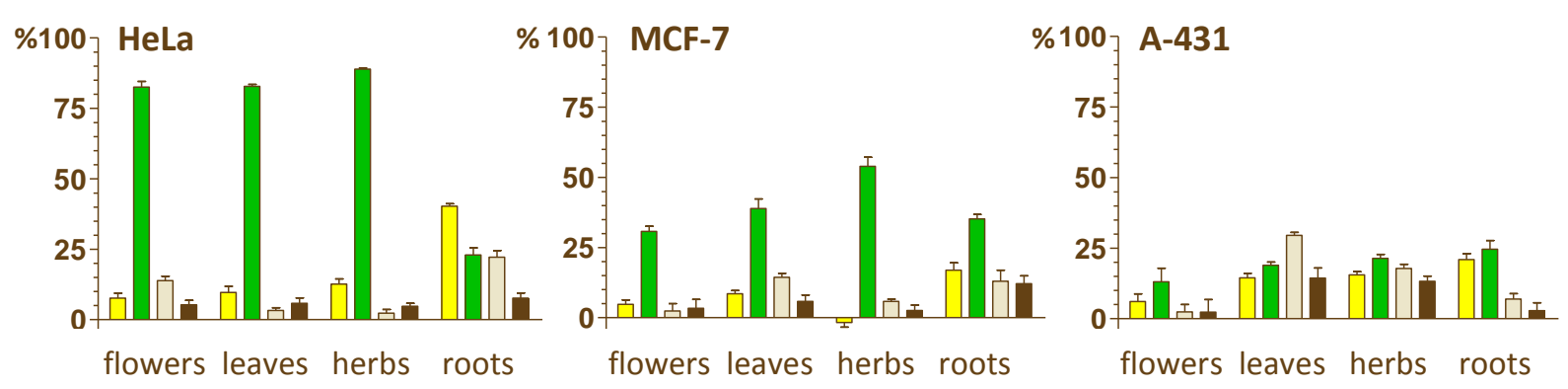

Figure 4. Antiproliferative activity of extracts of $A$. collina at $10 \mu \mathrm{g} / \mathrm{ml}$ (inhibition of proliferation, \%)

$\square n$-hexane fractions (A) $\square \mathrm{CHCl}_{3}$ fractions (B) $\square 50 \% \mathrm{MeOH}$ fractions (C) $\square \mathrm{H}_{2} \mathrm{O}$ fractions (D)

Since the dried aerial parts of yarrow were available commercially in Hungary as Achilleae herba (Achillea millefolium s.l.), investigation of this material was proposed. Before the preparative work 
was started, the extracts of Achilleae herba were also tested by the methods previously applied (see sections 4.3.1 and 4.6). Comparison of the results for the $\mathrm{CHCl}_{3}$-soluble fraction [80.4\% (HeLa), 47.6\% (MCF-7) and 9.5\% (A-431)] with those obtained from the primary screening [88.9\% (HeLa), 53.9\% (MCF-7) and 21.4\% (A-431)] indicated that there was no significant difference between the effects of the two samples of diverse origin.

\subsection{ISOLATION OF COMPOUNDS FROM CONYZA CANADENSIS}

After percolation of the air-dried and ground roots with $\mathrm{MeOH}$, the concentrated extract was diluted with $\mathrm{H}_{2} \mathrm{O}$ and subjected to solvent-solvent partition, first with $n$-hexane and then with $\mathrm{CHCl}_{3}$ (see section 4.3.2). After evaporation, the $n$-hexane-soluble phase $(16.0 \mathrm{~g})$ was fractionated by vacuum liquid chromatography (VLC-1), using mixtures of $n$-hexane and EtOAc with increasing polarity. A total of 103 fractions were collected and combined with regard to the results of TLC monitoring, yielding 12 main fractions (A/I-XII). From the marginally active fraction A/III, eluted with $n$-hexaneEtOAc 94:6, EC-3 was crystallized (71.5 mg). Fractions A/IV, A/V, A/VI, A/VII and A/VIII exerted pronounced antiproliferative activity and were analysed in detail.

Fraction A/IV (eluted with $n$-hexane-EtOAc 92:8), which displayed cell growth-inhibitory effects of $37.1 \%$ (HeLa), $77.2 \%$ (MCF-7) and 63.2\% (A-431), was chromatographed by rotation planar chromatography on silica gel in 2 steps, first with a gradient system of $n$-hexane-acetone (RPC-1). The subfractions eluted with $n$-hexane-acetone 19:1 from RPC I were next purified by RPC (RPC-2) with cyclohexane-EtOAc 9:1 as developing system, affording EC-10 $(5.8 \mathrm{mg})$. Fraction A/IV also contained EC-9, isolated later from the active fraction A/VII.

From fraction A/V [eluent: $n$-hexane-EtOAc 92:8; cell proliferation inhibition: $52.9 \%$ (HeLa), 38.8\% (MCF-7) and 49.7\% (A431)], pure EC-1 was obtained as white crystals (187.0 mg). From the mother liquor of this substance, EC-7 (12.0 mg) was isolated by means of RPC (RPC-3), with a solvent system of $n$-hexane-acetone 9:1 as mobile phase.

Fraction A/VI [eluent: $n$-hexane-EtOAc 92:8; cell proliferation inhibition: $55.5 \%$ (HeLa), $65.7 \%$ (MCF-7) and 56.1\% (A-431)] was also subjected to RPC (RPC-4), with a solvent system of toluene$\mathrm{CH}_{2} \mathrm{Cl}_{2}$ 1:1, which resulted in the isolation of EC-6 $(11.1 \mathrm{mg})$.

In the prominently active fraction A/VII [eluent: $n$-hexane-EtOAc 9:1; cell proliferation inhibition: 87.3\% (HeLa), 85.5\% (MCF-7) and 84.6\% (A-431)] EC-10, isolated previously from fraction A/IV, was identified as a minor constituent. To obtain the main component, VLC was applied (VLC-2), with mixtures of $n$-hexane-acetone of increasing polarity as eluents. The subfractions eluted with $n$ - 
hexane-acetone $92: 8$ in this separation were purified by RPC (RPC-5), with petroleum ether- $\mathrm{CH}_{2} \mathrm{Cl}_{2}$ 1:1 as solvent system, which yielded EC-9 (139.2 mg).

For the separation of fraction A/VIII [eluent: $n$-hexane-EtOAc 8:2; cell proliferation inhibition: $55.9 \%$ (HeLa), 55.4\% (MCF-7) and 52.4\% (A-431)], a subsequent RPC was carried out (RPC-6), with the application of gradient elution ( $n$-hexane-EtOAc). From the subfractions eluted with $n$-hexane-EtOAc 7:3, a crystalline material, EC-4, was obtained $(24.5 \mathrm{mg})$. From the subfractions eluted with $n$ hexane-EtOAc 6:4, another substance was crystallized, which was purified by preparative layer chromatography (PLC-1) on silica gel (eluent: $n$-hexane-EtOAc 13:5); this afforded EC-5 (9.8 mg).

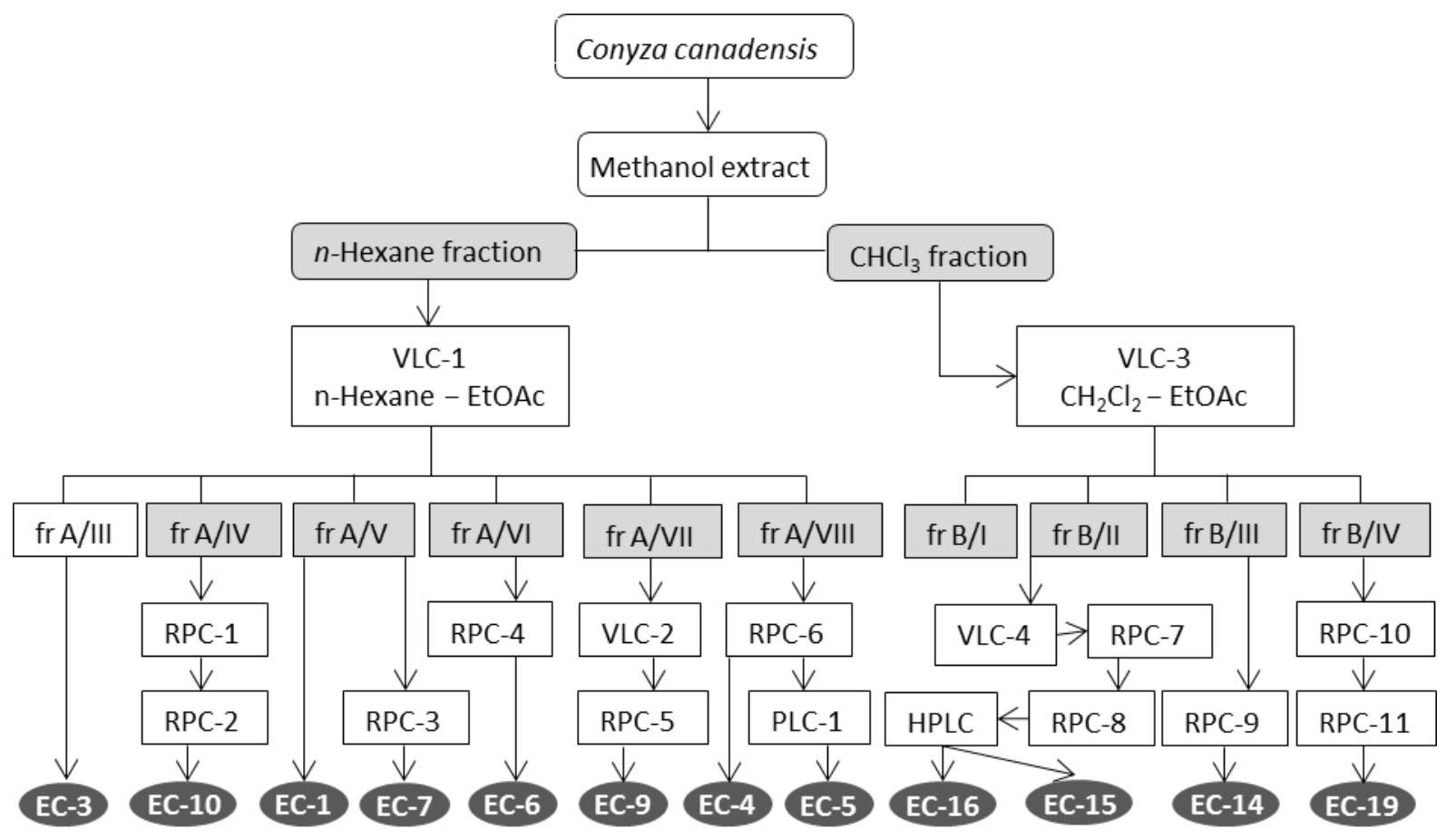

Figure 5. Isolation of compounds from C. canadensis. The biologically active fractions are highlighted with a marked background ( $\square$ ).

The $\mathrm{CHCl}_{3}$-soluble phase of the extract (20.4 g) was chromatographed via VLC, using a gradient system of $\mathrm{CH}_{2} \mathrm{Cl}_{2}-\mathrm{MeOH}$ (VLC-3). The combination of the collected fractions (42) resulted in 5 main fractions (B/I-V). In fraction $\mathrm{B} / \mathrm{I}$ (eluted with $\mathrm{CH}_{2} \mathrm{Cl}_{2}-\mathrm{MeOH}$ 98:2), which exhibited marked antitumour effects [69.4\% (HeLa), 80.3\% (MCF-7) and 47.6\% (A-431)], EC-9 and EC-10 were identified as main constituents. Fractions B/II, B/III and B/IV demonstrated moderate activity in the bioassays.

Fraction B/II [eluent: $\mathrm{CH}_{2} \mathrm{Cl}_{2}-\mathrm{MeOH}$ 96:4; cell growth inhibition: 36.7\% (HeLa), 38.2\% (MCF-7) and $35.6 \%$ (A-431)] was subjected to VLC, with a mixture of toluene-EtOAc-acetone of increasing polarity (VLC-4). The subfractions eluted with toluene-EtOAc-acetone 6:3:1 were separated by RPC in two 
steps: RPC-7 was carried out on $\mathrm{Al}_{2} \mathrm{O}_{3}$ as sorbent, with gradient elution (cyclohexane- $\mathrm{CH}_{2} \mathrm{Cl}_{2}-\mathrm{MeOH}$ ), while the subfractions of RPC-7 eluted with cyclohexane- $-\mathrm{CH}_{2} \mathrm{Cl}_{2}-\mathrm{MeOH}$ 20:20:1 were purified on silica gel, with $n$-hexane-EtOAc 3:2 (RPC-8), which resulted in a mixture of 2 compounds, separated subsequently by RP-HPLC with $\mathrm{MeOH}-\mathrm{H}_{2} \mathrm{O} 3: 2$ as mobile phase to furnish EC-15 (15.3 mg) and EC-16 (7.6 mg).

Fraction $\mathrm{B} / \mathrm{III}$ [eluted with $\mathrm{CH}_{2} \mathrm{Cl}_{2}-\mathrm{MeOH}$ 94:6; cell growth inhibition: 28.4\% (HeLa), 26.4\% (MCF-7) and $19.1 \%$ (A-431)] was fractionated by RPC, with a gradient system of $n$-hexane-EtOAc-MeOH (RPC9). From the subfractions eluted with this system at 5:4:1, EC-14 was crystallized (10.6 mg).

Fraction B/IV [eluent: $\mathrm{CH}_{2} \mathrm{Cl}_{2}-\mathrm{MeOH}$ 9:1; cell proliferation inhibition: 29.7\% (HeLa), 35.1\% (MCF-7) and $43.8 \%$ (A-431)] was processed by a similar method as used for fraction B/III (RPC-10), and the subfractions eluted with EtOAc-MeOH 1:1 were then purified by a subsequent RPC (RPC-11), with $n$ hexane-acetone-MeOH 6:14:5 as eluent, which resulted in the isolation of EC-19 (5.4 mg).

\subsection{ISOLATION OF COMPOUNDS FROM ACHILLEA MILLEFOLIUM S.L.}

Achilleae herba was percolated with $\mathrm{MeOH}$; the extract was subjected to solvent-solvent partition between $n$-hexane, $\mathrm{CHCl}_{3}$ and $\mathrm{H}_{2} \mathrm{O}$ (see section 4.3.2). After evaporation, the $\mathrm{CHCl}_{3}$-soluble phase (45 g) was fractionated by VLC (VLC-5) on silica gel, using a gradient system of $n$-hexane-EtOAc-MeOH (Figure 6). The combination of fractions of similar composition furnished 8 main fractions (I-VIII), which were tested for their antitumour effect. Fraction II (eluted with $n$-hexane-EtOAc 1:1), fraction III (eluent: $n$-hexane-EtOAc 1:1 and 3:7) and fraction IV (eluent: $n$-hexane-EtOAc 3:7 and EtOAc) were found to display high antiproliferative activities, and were therefore analysed further.

Fraction II [cell growth inhibition: 85.7\% (HeLa), 57.3\% (MCF7) and 30.2\% (A431)] was separated in the following VLC (VLC-6), using a solvent system of toluene-acetone with increasing polarity. The subfractions obtained with toluene-acetone 3:7 and acetone were fractionated by RPC (RPC-12) on silica gel, with a gradient system of cyclohexane- $\mathrm{CH}_{2} \mathrm{Cl}_{2}-\mathrm{MeOH}$. From the subfractions eluted with this system at 5:15:1, AC-11 (3.5 mg) was obtained in crystalline form.

From the active fraction III [inhibitory potency: 79.1\% (HeLa), 56.7\% (MCF7) and 81.8\% (A431)], pure AC-1 was crystallized (35.4 mg). The mother liquor was fractionated by means of VLC (VLC-7; solvent system: toluene-acetone with increasing polarity). The subfractions eluted with tolueneacetone 7:3 were further purified by RPC (RPC-13) with cyclohexane- $\mathrm{CH}_{2} \mathrm{Cl}_{2}-\mathrm{MeOH}$ 20:20:1 as eluent, yielding AC-3 $(4.8 \mathrm{mg})$ and AC-6 $(8.0 \mathrm{mg})$ as crystalline materials. Preparative layer chromatography (PLC-2) of the following subfraction of RPC-13, using cyclohexane- $\mathrm{CH}_{2} \mathrm{Cl}_{2}-\mathrm{MeOH}$ 
10:30:1 as the solvent system, resulted in the isolation of AC-5 $(5.0 \mathrm{mg})$. From the subfractions eluted from VLC-7 with toluene-acetone 7:3 and 6:4, AC-2 $(21.6 \mathrm{mg})$ was crystallized in pure form.

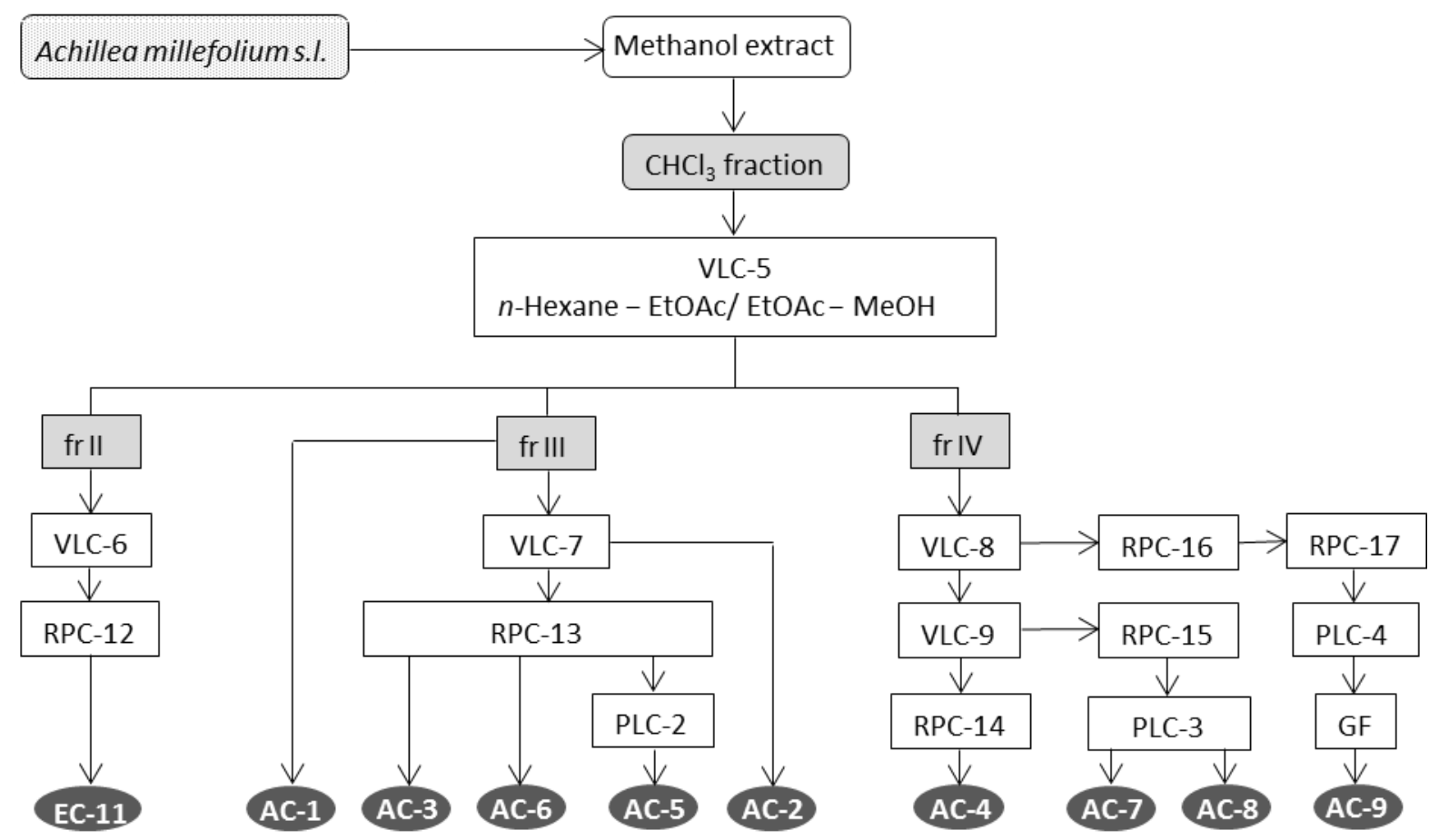

Figure 6. Isolation of compounds from A. millefolium s.I. The biologically active fractions are higlighted with a marked background ( $\square$ ).

Active fraction IV [cell growth inhibition: 88.0\% (HeLa), 50.2\% (MCF7) and 25.4\% (A431)] was separated by repeated VLC (VLC-8) with the use of a gradient system of toluene-acetone. The subfractions eluted with this system at 1:1 and 4:6 were combined and fractionated by VLC (VLC-9) with gradient elution, using mixtures of $n$-hexane and acetone. The subfractions eluted with $n$ hexane-acetone 4:6 were subjected to RPC (RPC-14; mobil phase: $\mathrm{CHCl}_{3}-\mathrm{MeOH}$ 99:1), affording the crystalline AC-4 (17.5 mg, mp. $\left.153-154^{\circ} \mathrm{C}\right)$. A subsequent separation of the subfractions eluted with $n$-hexane-acetone 3:7 and acetone from VLC-9 was carried out by RPC (RPC-15), applying gradient elution (cyclohexane- $\mathrm{CH}_{2} \mathrm{Cl}_{2}-\mathrm{MeOH}$ ). The final separation of the subfractions obtained with the above system at 7:13:1 by means of PLC (PLC-3; mobile phase: cyclohexane- $\mathrm{CH}_{2} \mathrm{Cl}_{2}-\mathrm{EtOAc}-\mathrm{MeOH}$ 7:6:8:1) led to the isolation of AC-7 (3.7 mg) and AC-8 (5.5 mg). Other subfractions of VLC-8 (elutents: toluene-acetone 2:8 and acetone) were purified by RPC, first with a gradient system of cyclohexane$\mathrm{CH}_{2} \mathrm{Cl}_{2}-\mathrm{MeOH}$ (RPC-16), while the subfractions obtained from this separation (eluent: $\mathrm{CH}_{2} \mathrm{Cl}_{2}-\mathrm{MeOH}$ 3:1) were subjected to chromatography with an isocratic system of acetone-MeOH 1:1 (RPC-17). Further PLC (PLC-4; $\mathrm{CHCl}_{3}-\mathrm{MeOH}$ 9:1) and gel filtration led to the isolation of AC-9 (9.9 mg). 


\subsection{ChARACTERIZATION AND STRUCTURE DETERMINATION OF THE ISOLATED COMPOUNDS}

The structure elucidation was performed by means of spectroscopic methods (see section 4.5). Information from $1 \mathrm{D}\left({ }^{1} \mathrm{H}\right.$ NMR and JMOD) and in some cases from $2 \mathrm{D}\left({ }^{1} \mathrm{H},{ }^{1} \mathrm{H}\right.$ COSY, NOESY, HSOC and HMBC) NMR experiments proved valuable for the structure determination. The HREIMS and ESIMS spectra allowed determination of the molecular mass and the molecular compositions.

\subsubsection{Compounds in Conyza canadensis}

EC-9 and EC-10 were isolated as brownish-yellow oils. The data obtained from extensive 1D and 2D NMR $\left({ }^{1} \mathrm{H}-{ }^{1} \mathrm{H}\right.$ COSY, NOESY, HSQC and HMBC) studies confirmed the presence of 2 isomeric compounds containing a $C_{10}$ unsaturated skeleton. EC-9 was identified as $4 E, 8 Z$-matricaria- $\nu$-lactone (72) and EC-10 as 4Z,8Z-matricaria- $\gamma$-lactone (73), typical constituents of the tribe Astereae, isolated previously from the roots of C. canadensis, ${ }^{79} \mathrm{C}$. linifolia and Erigeron and Solidago ${ }^{107,108}$ species. Complete ${ }^{1} \mathrm{H}$ and ${ }^{13} \mathrm{C}$ chemical shift assignments were achieved for the compounds in $\mathrm{CDCl}_{3}$, and the data reported previously by LAM $^{107}$ were supplemented. ${ }^{109}$

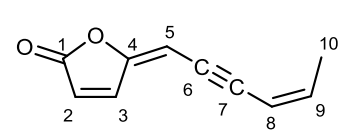

72 (EC-9)

4E,8Z-matricaria- $\gamma$ lactone

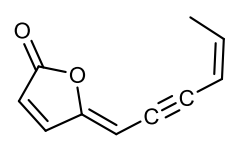

73 (EC-10)

4Z,8Z-matricaria- $\gamma$ lactone

EC-16 was obtained as a colourless oil $\left([\alpha]_{D}^{29} 0, c=0.1, \mathrm{CHCl}_{3} ; \mathrm{UV} \lambda_{\max }(\mathrm{MeOH}) \mathrm{nm}(\log \varepsilon) 241\right.$ (2.56), 306 (2.74); positive ESIMS: $m / z 211[\mathrm{M}+\mathrm{H}]^{+}$). Its UV absorption indicated a conjugated enone system. On the basis of the ESIMS spectrum, its molecular mass was established as 210 . The ${ }^{1} \mathrm{H}$ NMR spectrum displayed 14 proton signals, and the ${ }^{13} \mathrm{C}$ NMR spectrum 11 carbon resonances (Table 2), indicating the molecular composition $\mathrm{C}_{11} \mathrm{H}_{14} \mathrm{O}_{4}$. The presence of one methoxy group was readily recognized from the signals at $\delta_{\mathrm{H}} 3.81 \mathrm{~s}(3 \mathrm{H})$ and $\delta_{\mathrm{C}}$ 52.1. Analysis of the ${ }^{1} \mathrm{H},{ }^{1} \mathrm{H}$ COSY and HSQC spectra provided information that allowed identification of 1 primary methyl, 2 methylene and 4 methine groups, and 3 quaternary carbons, including 1 keto $\left(\delta_{\mathrm{C}} 193.3\right)$ and 1 carbonyl group $\left(\delta_{\mathrm{C}}\right.$ 165.9). The proton-proton connectivities detected in the ${ }^{1} \mathrm{H},{ }^{1} \mathrm{H}$ COSY spectrum revealed the existence of 2 sequences of correlated protons: $\mathrm{CH}_{3}-\mathrm{CH}_{2}-\mathrm{CH}-\mathrm{CH}_{2}-$ [fragment $\mathrm{A}, \delta_{\mathrm{H}} 1.07(3 \mathrm{H}), 1.79$ $(1 \mathrm{H}), 1.90(1 \mathrm{H}), 4.38(1 \mathrm{H}), 2.50(2 \mathrm{H})$ ] and a disubstituted olefin group with trans geometry $\left(\delta_{\mathrm{H}} 7.05 \mathrm{~d}\right.$, $6.59 \mathrm{~d}, J=15.6 \mathrm{~Hz}$ ). Moreover, 1 isolated $s p^{2}$ methine was detected at $\delta_{\mathrm{H}} 5.59$ and $\delta_{\mathrm{C}}$ 109.7. The overall structure was assembled by analysis of the long-range $\mathrm{C}-\mathrm{H}$ correlations gained from an $\mathrm{HMBC}$ experiment. Two- and 3-bond correlations of the quaternary carbon at $\delta_{\mathrm{C}} 193.3$ (C-6) with the protons at $\delta_{\mathrm{H}} 5.59(\mathrm{H}-5), 2.50(\mathrm{H}-7)$, and $4.38(\mathrm{H}-8)$ demonstrated that the isolated methine and fragment $A$ are connected through the keto group. This was corroborated by the HMBC correlations 
between $\mathrm{C}-5$ and $\mathrm{H}-7$, and $\mathrm{C}-7$ and $\mathrm{H}-5$. The long-range couplings of the carbonyl carbon at $\delta_{\mathrm{C}} 165.9$ (C-1) with the olefin protons at $\delta_{\mathrm{H}} 7.05(\mathrm{H}-3)$ and $6.59(\mathrm{H}-2)$ and the methyl group at $\delta_{\mathrm{H}} 3.81$ proved a $-\mathrm{CH}=\mathrm{CH}-\mathrm{COOCH}_{3}$ structural moiety (B) in the molecule. Fragments $\mathrm{A}$ and $\mathrm{B}$ were connected with the aid of the HMBC cross-peaks between C-4 $\left(\delta_{\mathrm{C}} 165.2\right)$ and $\mathrm{H}-2, \mathrm{H}-3$ and $\mathrm{H}-5$, and the correlations of C5 with $\mathrm{H}-3$, resulting in the overall structure $\mathbf{7 4}$ for which the trivial name conyzapyranone $A$ was given. The stereochemistry was determined in a NOESY experiment. The Overhauser effect between $\mathrm{H}-5$ and $\mathrm{H}-3$ revealed the steric proximity of these protons. EC-16 has 1 stereogenic centre, $\mathrm{C}-8$, but the optical rotation data are indicative of a racemic mixture.

Table 2. ${ }^{1} \mathrm{H}$ and ${ }^{13} \mathrm{C}$ NMR data on EC-16 and EC-15 [500 MHz $\left.\left({ }^{1} \mathrm{H}\right), 125 \mathrm{MHz}\left({ }^{13} \mathrm{C}\right), \mathrm{CDCl}_{3}, \delta \mathrm{ppm}(J=\mathrm{Hz})\right]$

\begin{tabular}{lllll}
\hline Position & EC-16 & \multicolumn{3}{l}{ EC-15 } \\
& ${ }^{1} \mathbf{H}$ & ${ }^{13} \mathbf{C}$ & ${ }^{1} \mathbf{H}$ & ${ }^{13} \mathbf{C}$ \\
\hline 1 & - & 165.9 & - & 166.7 \\
2 & $6.59 \mathrm{~d}(15.6)$ & 125.2 & $6.13 \mathrm{~d}(12.4)$ & 127.0 \\
3 & $7.05 \mathrm{~d}(15.6)$ & 137.4 & $6.17 \mathrm{~d}(12.4)$ & 129.2 \\
4 & - & 165.2 & - & 166.0 \\
5 & $5.59 \mathrm{~s}$ & 109.7 & $5.49 \mathrm{~s}$ & 107.8 \\
6 & - & 193.3 & - & 193.4 \\
$7 \mathrm{a}$ & $2.50 \mathrm{~m}(2 \mathrm{H})$ & 41.2 & $2.51 \mathrm{dd}(16.9,12.6)$ & 40.7 \\
$7 \mathrm{~b}$ & & & $2.42 \mathrm{dd}(16.8,3.4)$ & \\
8 & $4.38 \mathrm{~m}$ & 80.6 & $4.37 \mathrm{~m}$ & 80.9 \\
$9 \mathrm{a}$ & $1.90 \mathrm{~m}$ & 27.5 & $1.81 \mathrm{~m}$ & 27.4 \\
$9 \mathrm{~b}$ & $1.79 \mathrm{~m}$ & & $1.75 \mathrm{~m}$ & \\
10 & $1.07 \mathrm{t} \mathrm{(7.4)}$ & 9.3 & $1.01 \mathrm{t}(7.5)$ & 9.0 \\
OMe & $3.81 \mathrm{~s}$ & 52.1 & $3.79 \mathrm{~s}$ & 51.9 \\
\hline
\end{tabular}

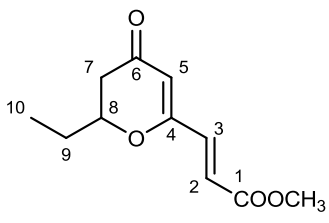

74 (EC-16)

conyzapyranone $\mathrm{A}$

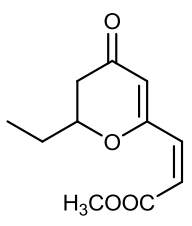

75 (EC-15)

conyzapyranone B

EC-15 was obtained as a colourless oil $\left([\alpha]_{D}^{29} 0, c=0.1, \mathrm{CHCl}_{3} ; \mathrm{UV} \lambda_{\max }(\mathrm{MeOH}) \mathrm{nm}(\log \varepsilon) 228\right.$ (2.33), 294 (2.71); positive ESIMS: $m / z 211[\mathrm{M}+\mathrm{H}]^{+}$). The ESIMS and ${ }^{1} \mathrm{H}$ NMR and JMOD spectra (Table 2.) of EC-15 indicated the same molecular mass and composition as in the case of EC-16. The $\mathrm{HSQC}$ and ${ }^{1} \mathrm{H}^{1} \mathrm{H}$ COSY experiments on EC-15 allowed identification of the same scalarly coupled spin systems $\mathrm{CH}_{3}-\mathrm{CH}_{2}-\mathrm{CH}_{-}-\mathrm{CH}_{2}-(\mathrm{A})$ and $-\mathrm{CH}=\mathrm{CH}-\mathrm{COOCH}_{3}(\mathrm{~B}), 1$ isolated methine and 2 quaternary carbons. Via the HMBC correlations, the same assignments of the subunits were elucidated. The only significant difference was observed in the coupling constant and ${ }^{13} \mathrm{C}$ chemical shifts of the disubstituted olefin. The coupling constant value, $J=12.4 \mathrm{~Hz}$, demonstrated the cis geometry of the C-2-C-3 double bond. For EC-15, a Overhauser effect was detected between $\mathrm{H}-3$ and H-5; accordingly, its structure can be formulated as $\mathbf{7 5}$ and the trivial name conyzapyranone B was given. For this 
compound too, the presence of 2 enantiomers (in a ratio of 1: 1) was indicated by the optical rotation data.

EC-19 was obtained as white solid (m.p. $144-147^{\circ} \mathrm{C}$; positive ESIMS: $m / z 348\left[\mathrm{M}+\mathrm{NH}_{4}\right]^{+}, 353[\mathrm{M}+\mathrm{Na}]^{+}$; negative ESIMS: $m / z 329\left[\mathrm{M}-\mathrm{H}^{-}\right.$) and identified as 9,12,13-trihydroxy-10E-octadecenoic acid (76), a fatty acid isolated previously from Salsola tetranda $a^{110}$. The ${ }^{1} \mathrm{H}$<smiles>CCCCCCC(O)C(O)/C=C/C(O)CCCCCCC(=O)O</smiles>
NMR data were in good agreement with the literature values. ${ }^{110}$ For EC-19, complete ${ }^{13} \mathrm{C}$ NMR data were determined. ${ }^{109}$

EC-3 was isolated as white crystals (m.p. $257-260^{\circ} \mathrm{C}$ ). Analysis of the spectral data from the ${ }^{1} \mathrm{H}$ NMR and JMOD measurements suggested a friedelane triterpenoid structure containing a keto group. On the basis of its NMR data, EC-3 proved to be identical with friedeline ${ }^{111}(\mathbf{4 1})$, isolated earlier from C. canadensis by XIE et al. ${ }^{84}$ and also detected in $C$. blinii. $^{112}$

EC-1 was isolated as white crystals (m.p. $291-292{ }^{\circ} \mathrm{C}$ ). ${ }^{1} \mathrm{H}$ NMR and JMOD spectra indicated a friedelane-type triterpene skeleton, which,

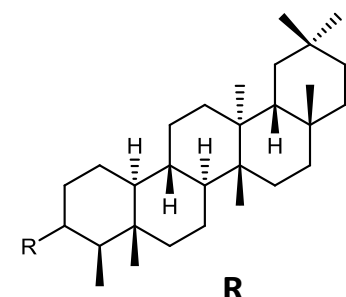

$41(\mathrm{EC}-3) \quad=0$ friedeline 42 (EC-1) $\quad 6-\mathrm{OH}$ epifriedelanol unlike EC-3, contains a hydroxy group. By comparison of the spectral data with those published in the literature ${ }^{113}$, it was concluded that the compound was identical with epifriedelanol (42), isolated earlier from C. canadensis by XIE et al. ${ }^{84}$

EC-6 was obtained as white crystals (m.p. $283-285^{\circ} \mathrm{C}$ ). The NMR spectra indicated that the compound is a taraxerane-type triterpene. On the basis of its spectral data, EC-6 proved to be identical with taraxerol $^{114}$ (77), detected earlier in many plants, including some representatives (Barringtonia, Gochnatia, Atractylodes and Mikania species) of the Asteraceae. ${ }^{114-118}$

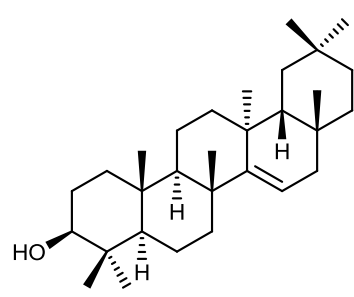

77 (EC-6) taraxerol

EC-7 was obtained as white crystals (m.p. $203-205^{\circ} \mathrm{C}$ ). The spectral analysis elucidated its structure as a triterpene alcohol. The spectral data on EC-7 were in agreement with those published by Yoo ${ }^{119}$ and it was therefore identified as simiarenol (78), a rare compound with an adianane skeleton, previously described in the closely related species Erigeron annus ${ }^{119}$ and Artemisia stolonifera. ${ }^{120}$

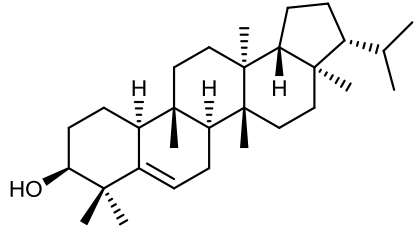

78 (EC-7) simiarenol 
EC-5 was isolated as white crystals (m.p. $254-257^{\circ} \mathrm{C}$ ). The comparison of its spectral data with those reported in the literature ${ }^{121}$ resulted in the identification of spinasterol (36), a compound isolated earlier from $C$. canadensis by XIE et al. ${ }^{84}$

EC-4 was isolated as white crystals. Analysis of its NMR spectra led to the conclusion that the isolated substance was a mixture of stigmasterol (37) and 8 -sitosterol (38), both isolated earlier from C. canadensis by MUKHTAR et $a .^{82}$

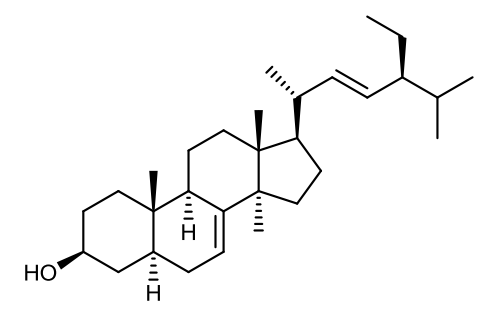

36 (EC-5) spinasterol

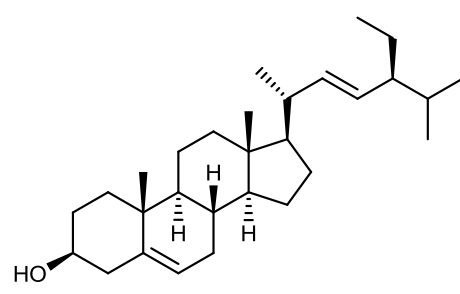

37 (EC-4) stigmasterol

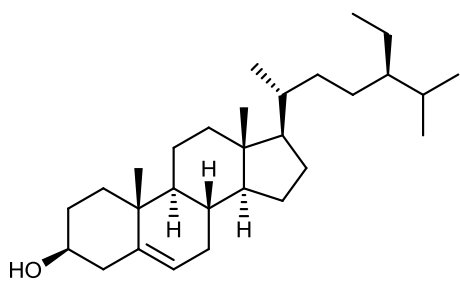

38 (EC-4) B-sitosterol

EC-14 was isolated as a yellow amorphous solid. On the basis of the 1D NMR spectra, ${ }^{122}$ it was identified as apigenin (13), detected in C. canadensis by CZECZOT et al. ${ }^{81}$

\subsubsection{Compounds in Achillea millefolium s.l.}

AC-1 and AC-9, yellow amorphous solids, were identified as apigenin (13) and luteolin (14), respectively, on the basis of their spectral data, ${ }^{122}$ and, in the case of AC-1, by co-chromatography with EC-14. Both are known flavones of the A. millefolium aggregate. $^{103}$

AC-3, AC-2 and AC-5 were obtained as yellow crystals. As a result of ${ }^{1} \mathrm{H}$ and ${ }^{13} \mathrm{C}$ NMR investigations, the compounds were<smiles>O=c1cc(-c2ccc(O)c(P)c2)oc2cc(O)cc(O)c12</smiles>
$\mathrm{R}$

H 13 (EC-14; AC-1)

apigenin $\mathrm{OH} 14$ (AC-9) luteolin identified as artemetin (62), casticin (63) and centaureidin (64), respectively, by comparison of their spectral data with those published in the literature. ${ }^{104,122-125}$ All are flavonols already described in the A. millefolium aggregate. ${ }^{103,104}$<smiles>COc1ccc(-c2oc3cc(OC)c(OC)c(O)c3c(=O)c2OC)cc1OC</smiles>

62 (AC-3) artemetin<smiles>COc1ccc(-c2oc3cc(OC)c(OC)c(O)c3c(=O)c2O)cc1OC</smiles>

63 (AC-5) casticin<smiles>COc1ccc(-c2oc3cc(O)c(OC)c(O)c3c(=O)c2OC)cc1O</smiles>

64 (AC-2) centaureidin 
AC-7 and AC-8 were obtained as white crystals (m.p. $174-177^{\circ} \mathrm{C}$ and $183-188^{\circ} \mathrm{C}$, respectively). The HREIMS spectra confirmed that the 2 compounds have the same molecular mass $(\mathrm{m} / \mathrm{z} 276)$ and composition $\left(\mathrm{C}_{15} \mathrm{H}_{16} \mathrm{O}_{5}\right)$. The ${ }^{1} \mathrm{H}$ and ${ }^{13} \mathrm{C} N M R$ measurements also suggested a high degree of structural similarity. The 2D NMR $\left({ }^{1} \mathrm{H}-{ }^{1} \mathrm{H}\right.$ COSY, NOESY, HSQC and HMBC) measurements indicated that the molecules are pseudoguaianolides possessing 2 lactone rings, an epoxy group and an unsaturated bond. On comparison of the spectral data of the 2 compounds with those published in the literature ${ }^{126}$, AC-7 and AC-8 were identified as paulitin (79) and isopaulitin (80), respectively, stereoisomers bearing seco-pseudoguaianolide skeleton, isolated previously from Ambrosia artemisiifolia and A. cumanensis. ${ }^{126}$ The $2 \mathrm{D}$ NMR investigations permitted correction of the previously reported ${ }^{13} \mathrm{C}$ NMR assignments ${ }^{126}$ and complete ${ }^{1} \mathrm{H}$ chemical shift assignments for paulitin (79) and isopaulitin (80). ${ }^{127}$

AC-11 was isolated as white crystals (m.p. $223-225^{\circ} \mathrm{C}$ ) The ${ }^{1} \mathrm{H}$ and ${ }^{13} \mathrm{C}$ NMR investigations suggested that the compound is another secopseudoguaianolide derivative, but lacking the epoxy group. On the basis of its spectral data, AC-11 was identified as psilostachyn C, isolated earlier from Ambrosia psilostachya, $A$. arborescens and A. artemisiifolia. ${ }^{128-130}$ The previously reported ${ }^{1} \mathrm{H}$ NMR assignments for psilostachyin $C^{128}(\mathbf{8 1})$ were supplemented. ${ }^{127}$

AC-4 was isolated as colourless crystals (m.p. $153-154{ }^{\circ} \mathrm{C}$ ). ${ }^{1} \mathrm{H}$ and ${ }^{13} \mathrm{C}$ chemical shift assignments indicated a SLS structure containing a dienone function. The spectral data on AC-4 matched well with those reported for desacetylmatricarin (= austricin) ${ }^{104}(\mathbf{5 4})$, a frequently occuring guaianolidetype compound in the Achillea genus. ${ }^{92,131}$

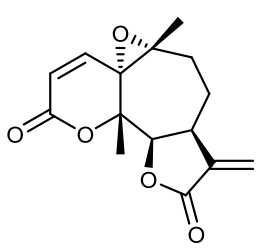

79 (AC-7) paulitin

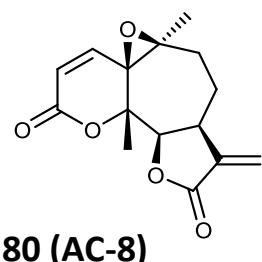

isopaulitin

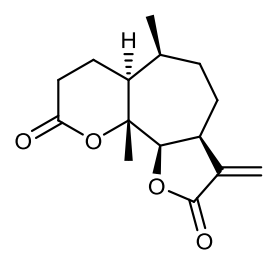

81 (AC-11) psilostachyin C

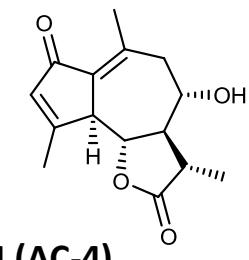

54 (AC-4)

desacetylmatricarin

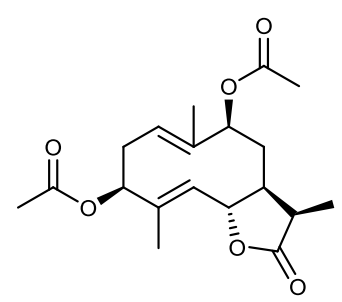

82 (AC-6) sintenin 


\subsection{Pharmacological ASSESSMENT OF THE ISOLATED COMPOUNDS}

\subsubsection{Compounds in Conyza canadensis}

Activity-guided investigations of the $n$-hexane-soluble fraction of the lipophilic extract of horseweed root resulted in the isolation of 8 materials, identified as $4 E, 8 Z$-matricaria- $\nu$-lactone (72), 4Z,8Zmatricaria- $\gamma$-lactone(73), friedeline (41), epifriedelanol (42), taraxerol (77), simiarenol (78), spinasterol (36), and a mixture of stigmasterol (37) and 6 -sitosterol (38), while the $\mathrm{CHCl}_{3}$-soluble fraction furnished conyzapyranone A (74), conyzapyranone B (75), 9,12,13-trihydroxy-10Eoctadecenoic acid (76) and apigenin (13). The compounds were tested in vitro for their antiproliferative activities on the HeLa, MCF-7 and A-431 cancer cell lines, using the MTT assay (see section 4.6). For the active compounds, an additional set of MTT assays was performed on noncancerous MRC- 5 cells in order to evaluate the selectivity of the currently presented antiproliferative action. The measured cell growth-inhibitory potencies, expressed as $I_{50}$ values in $\mu \mathrm{M}$, are shown in Table 3. For the co-crystals of $\mathbf{3 7}$ and $\mathbf{3 8}$, the $\mathrm{IC}_{50}$ values are expressed in $\mu \mathrm{g} / \mathrm{ml}$. "Inactive" indicates that the compound elicited less than $50 \%$ inhibition of cell proliferation at $30 \mu \mathrm{g} / \mathrm{ml}$, and no higher concentration was tested.

Table 3. Antiproliferative effects of the compounds in C. canadensis on tumour and non-tumour cell lines

\begin{tabular}{|c|c|c|c|c|c|}
\hline \multirow{2}{*}{\multicolumn{2}{|c|}{ Compound }} & \multicolumn{4}{|c|}{$\mathrm{IC}_{50}$ values $(\mu \mathrm{M})$} \\
\hline & & \multirow{2}{*}{$\begin{array}{l}\text { HeLa } \\
24.46\end{array}$} & \multirow{2}{*}{$\begin{array}{l}\text { MCF-7 } \\
18.74\end{array}$} & \multirow{2}{*}{$\begin{array}{l}\text { A-431 } \\
22.81\end{array}$} & \multirow{2}{*}{$\begin{array}{l}\text { MRC-5 } \\
73.75\end{array}$} \\
\hline EC-9 & $4 E, 8 Z$-Matricaria- $\gamma$-lactone $(\mathbf{7 2})$ & & & & \\
\hline EC-10 & $4 Z, 8 Z$-Matricaria- $\gamma$-lactone (73) & 27.03 & 6.90 & 32.45 & 28.10 \\
\hline EC-16 & Conyzapyranone A (74) & 61.40 & 48.20 & 35.32 & 61.12 \\
\hline EC-15 & Conyzapyranone B (75) & 31.83 & 46.00 & 37.13 & 79.63 \\
\hline EC-19 & $\begin{array}{l}\text { 9,12,13-Trihydroxy-10E- } \\
\text { octadecenoic acid (76) }\end{array}$ & inactive & inactive & inactive & not tested \\
\hline EC-3 & Friedeline (41) & inactive & inactive & inactive & not tested \\
\hline EC-1 & Epifriedelanol (42) & 16.39 & 61.43 & 5.40 & inactive \\
\hline EC-6 & Taraxerol (77) & inactive & inactive & 2.65 & inactive \\
\hline EC-7 & Simiarenol (78) & inactive & inactive & inactive & not tested \\
\hline EC-5 & Spinasterol (36) & 13.93 & 26.50 & 13.66 & 71.14 \\
\hline EC-14 & Apigenin (13) & 10.64 & 13.88 & 12.34 & $>100.00$ \\
\hline EC-4 & $\begin{array}{l}\text { Stigmasterol (37) } \\
+\beta \text {-Sitosterol (38) }\end{array}$ & inactive & inactive & $2.62^{*}$ & $11.31 *$ \\
\hline \multicolumn{2}{|c|}{ Doxorubicin } & 0.15 & 0.28 & $0.15(0.09 *)$ & $0.50(0.29 *)$ \\
\hline \multicolumn{2}{|c|}{ Cisplatin } & 12.43 & 9.63 & $2.84\left(0.85^{*}\right)$ & $4.11(1.23 *)$ \\
\hline
\end{tabular}

$* \ln \mu \mathrm{g} / \mathrm{ml}$

As concerns the antitumour activities, taraxerol (77) and epifriedelanol (42) exhibited the highest effects on $\mathrm{A}-431$ (IC $50.65 \mu \mathrm{M}$ and $5.40 \mu \mathrm{M}$, respectively), wile matricaria lactone 73 did so on MCF-7 
$\left(I C_{50} 6.90 \mu \mathrm{M}\right)$, and apigenin (13) did so on HeLa (IC $\left.C_{50} 10.64 \mu \mathrm{M}\right)$; in these cases, the measured activities were comparable to those of the reference compound cisplatin. The matricaria lactone $\mathbf{7 2}$, the pyranones $\mathbf{7 4}$ and $\mathbf{7 5}$, and spinasterol (36) demonstrated moderate antitumour action $\left(\mathrm{IC}_{50}\right.$ 13.66-61.4 $\mu \mathrm{M}$ ). Taraxerol (77) and the mixture of $\mathbf{3 7}$ and $\mathbf{3 8}$ proved to be effective only against A431 cells. Friedeline (41), simiarenol (78) and 9,12,13-trihydroxy-10E-octadecenoic acid (76) were found to be inactive.

As regards the selectivity between cancerous and normal cells, the $I C_{50}$ values of epifriedelanol (42), taraxerol (77), spinasterol (36) and apigenin (13) indicateted more pronounced toxicity on the malignant cell lines tested than against MRC- 5 cells.

\subsubsection{Compounds in Achillea millefolium s.l.}

Phytochemical investigation of the aerial parts of yarrow led to the isolation of 10 compounds, i.e. paulitin (79), isopaulitin (80), psilostachyin C (81), desacetylmatricarin (54), sintenin (82), artemetin (62), casticin (63), centaureidin (64), apigenin (13) and luteolin (14), the antitumour activities of which were evaluated in vitro on 3 cancer cell lines (Table 4).

Table 4. Antiproliferative effects of the compounds in A. millefolium s.I. on tumour cell lines

\begin{tabular}{lllll}
\hline \multirow{2}{l}{ Compound } & HeLa & IC 5 values $(\boldsymbol{\mu M})$ & \\
& & MCF-7 & A-431 \\
\hline AC-7 & Paulitin (79) & 4.76 & 1.96 & 1.48 \\
AC-8 $\quad$ Isopaulitin (80) & 11.82 & 13.68 & 6.95 \\
AC-11 & Psilostachyin C (81) & inactive & inactive & inactive \\
AC-4 $\quad$ Desacetylmatricarin (54) & inactive & inactive & inactive \\
AC-6 $\quad$ Sintenin (82) & inactive & inactive & inactive \\
AC-3 $\quad$ Artemetin (62) & inactive & inactive & inactive \\
AC-5 $\quad$ Casticin (63) & 1.29 & 1.52 & 3.58 \\
AC-2 $\quad$ Centaureidin (64) & 0.08 & 0.13 & 0.35 \\
AC-1 $\quad$ Apigenin (13) & 10.64 & 13.88 & 12.34 \\
AC-9 Luteolin (14) & 7.59 & 32.88 & 26.26 \\
Doxorubicin & 0.15 & 0.28 & 0.15 \\
Cisplatin & 12.43 & 9.63 & 2.84 \\
\hline
\end{tabular}

The MTT assays involving the 3 human cancer cell lines revealed that the most active compound was the flavonol centaureidin (64), with an excellent $I C_{50}$ of $0.08-0.35 \mu \mathrm{M}$, followed by casticin (63), paulitin (79), isopaulitin (80) and apigenin (13) (IC 50 1.29-13.88 $\mu \mathrm{M})$. Luteolin (14) demonstrated a weaker anticancer profile, while psilostachyin C (81), desacetylmatricarin (54), sintenin (82) and artemetin (62) did not exhibit an antiproliferative effect. 


\section{DISCUSSION}

Many species of the family Asteraceae have been applied traditionally as anticancer remedies and extensively researched for their antiproliferative action. The fact that systematic screening studies on the antitumour effects of these plants, and especially the European species, are scarce stimulated us to carry out a comprehensive study including assays of the in vitro antiproliferative activities of Asteraceae species found in Hungary and to investigate certain species for their components responsible for the bioactivity.

\subsection{SCREENING STUDY}

In the course of our preliminary screening, 50 species of the tribes Cynareae (13), Cichorieae (12), Astereae (6), Anthemideae (11), Inuleae (3) and Heliantheae (5) were evaluated against human tumour cell lines, as presented in Annex 1. Of the 420 tested extracts, 41 representing 21 plants exerted marked inhibitory potency, and moderate activities was measured for extracts of 22 species.

The study had the aim of gaining information on the anticancer properties of species from the Hungarian flora. However, some of the tested Artemisia species (A. asiatica, A. japonica and A. messerschmidtiana) are native to Asia and were therefore supplied from cultivars. These plants were included in the screen with regard to the close relation to $A$. annua applied as an anticancer plant. Other species were selected for investigation because of their documented anticancer use in folk medicine or their chemotaxonomic relationship to medicinal plants applied as antitumour agents. Additionally, some species originated from random collection. For the extraction of the plant samples, the amphipolar $\mathrm{MeOH}$ was used, which permitted the retrieval of lipophilic and polar components too. Liquid-liquid partitioning between $n$-hexane, $\mathrm{CHCl}_{3}$ and $\mathrm{H}_{2} \mathrm{O}$ afforded fractions of different polarity. In most cases, the $\mathrm{CHCl}_{3}$-soluble fractions $\mathrm{B}$ (31), and in particular those of the aerial plant parts (24), were found to be effective, in contrast with only a minority of the active samples obtained from fractions A (8) or C (2) and none at all from the $\mathrm{H}_{2} \mathrm{O}$-soluble fractions D. Since the SLs and flavonoids, common components of the Asteraceae that are regarded as anticancer agents, are mainly $\mathrm{CHCl}_{3}$-soluble substances and found in general in the aerial organs, it can be supposed that these compounds contribute to the antitumour activity of the $\mathrm{CHCl}_{3}$-soluble leaf and flower extracts, and the presence of other chemical structures can be expected primarily in the $n$ hexane fractions or in the root extracts.

For 41 extracts with marked cell growth-inhibitory potency, $I C_{50}$ values were calculated (Table 1). The National Cancer Institute Guidelines specify that extracts with $\mathrm{IC}_{50}$ values $<20 \mu \mathrm{g} / \mathrm{ml}$ can be 
regarded as active. ${ }^{134}$ When our results are considered from this aspect, it may be concluded that many of the tested Asteraceae species are promising sources of new natural products with antitumour properties.

\section{Relationship between bioactivity and traditional application}

For certain plants, the measured antiproliferative activities are in accordance with their traditional use documented by HARTWELL. ${ }^{7}$ As an example, preparations of Conyza canadensis and Erigeron annuus have been used in the USA as remedies for tumours. In our study, extracts of these plants, and especially the root extracts, exhibited high activity. By the same token, Ambrosia artemisiifolia, Helianthus annuus and Xanthium italicum have been applied against tumours and cancers in Latin America, and in line with this they were found to be effective. The relationship is even more evident in the case of $X$. italicum: its aerial and underground parts have also been reported to be traditionally used in the form of juice, and the antiproliferative effect was experimentally proven for all the investigated organs. Arctium lappa, used in many countries for the treatment of different types of tumours, proved to be highly active in the antiproliferative tests: the $\mathrm{CHCl}_{3}$ extract of the leaves exhibited a cell growth-inhibitory effect, with $I_{50}$ values against the three cell lines in the interval 2.76-4.55 $\mu \mathrm{g} / \mathrm{ml}$. The juice and leaves of Cichorium intybus have been applied in folk medicine against cancer of the uterus and gastrointestinal tumours. In accordance with these data, the $\mathrm{CHCl}_{3}$ extract of the leaves was found to be effective against MCF-7 and A-431 cells. Similarly, the juice of Onopordum acanthium has been considered in traditional medicine to be effective against cancerous ulcers, carcinoma of the face and other cancers, and the lipophilic extracts of the leaves were highly potent in the antiproliferative assays on all three cell lines $\left(\mathrm{IC}_{50} 4.54-6.53 \mu \mathrm{g} / \mathrm{ml}\right)$.

On the other hand, some of the plants exerted only a marginal effect on the cell lines used, or proved ineffective, in spite of their traditional use in cancer treatment. HARTWELL's series reported the ethnomedicinal use of Artemisia campestris, A. dracunculus, A. vulgaris, Tripleurospermum inodorum, Carduus acanthoides, Lactuca serriola, Sonchus oleraceus and Taraxacum officinale against cancers, warts and tumours. In the present tests, only moderate activities were recorded for these species. In contrast with their traditional use, no antitumour effects were detected in our assays for Anthemis tinctoria, Matricaria chamomilla and Tragopogon pratensis.

\section{Species worthy of activity-guided investigation}

A survey on the literature data of the investigated species did not reveal any earlier pharmacological or phytochemical studies on secondary metabolites of Anthemis ruthenica, Inula ensifolia, Centaurea 
biebersteinii, C. spinulosa and Cirsium vulgare. With regard to their high tumour cell growthinhibitory activities, these species can be regarded as promising sources of new cytostatic agents.

Certain plants found effective in our study have been more or less documented chemically or pharmacologically, but the active substances have not been identified, or presumably not completely exploited. For example, the chemical constituents of the highly active Achillea collina (see section 3.3.2), Conyza canadensis (see section 3.3.1), Erigeron annuus, ${ }^{135-137}$ Centaurea jacea (flavonoids, sesquiterpenes and cinnamic alcohol derivatives) ${ }^{138,139}$, Xanthium italicum (xanthanolides) $)^{140,141}$ and Lactuca viminea (phenolic compounds) ${ }^{142}$ had already been investigated, though at the same time these plants had not been studied for their antitumour substances. Earlier reports on Artemisia asiatica described only the apoptosis-inducing eupatilin, ${ }^{143}$ and on A. japonica ssp. littoricola, dehydrofalcarindiol ${ }^{60,144}$ and eugenol ${ }^{145}$ with antitumour effects, while only lupeol, amyrin, taraxasterol and its acetate and the cytotoxic onopordopicrin and arctiopicrin have been identified in Onopordum acanthium..$^{48,146}$ These plants probably contain further active compounds. From the aerial parts of Ambrosia artemisiifolia, the pseudoguaianolide paulitin and isopaulitin were isolated as antitumour constituents, ${ }^{126}$ but the active compounds in the root extracts are as yet unidentified. All of the above-mentioned species are worthy of bioassay-guided investigation in order to isolate further active compounds responsible for antitumour activity.

\subsection{INVESTIGATION OF CONYZA CANADENSIS AND ACHILLEA MILLEFOLIUM S.L.}

On the basis of the results of our preliminary screen and the literature survey of the tested species, 2 plants were selected for more detailed phytochemical examination. In the case of Conyza canadensis, horseweed, a plant traditionally used as a remedy against cancer, investigation of the roots seemed to be promising, since its $n$-hexane extract proved to exert excellent activity. The anticancer effect of the plant has not been evaluated previously. Furthermore, earlier phytochemical studies focused on the above-ground parts or the whole plant, and only a few compounds had been described in the roots (see section 3.3.1). Our primary concern was to study the highly active $n$-hexane fraction of the root extract, but, from a practical point of view, additional investigations of the moderately active $\mathrm{CHCl}_{3}$ fraction appeared obvious. Achillea millefolium s.l., yarrow, is a known medicinal plant with well-documented chemistry (see section 3.3.2). In folk medicine, it has been widely applied for the treatment of cancer-related diseases; however, experimental evidence of the antitumour properties of yarrow is limited. The $\mathrm{CHCl}_{3}$ extracts of the aerial parts of $A$. collina were found to be prominently active in the screen. For the preparative work, Achilleae herba of commercial origin (Achillea 
millefolium s.l.) was used as raw material because the collection and identification of $A$. collina seemed to be problematic. After assaying the extracts for antiproliferative activity, we concluded that there was no significant difference between the effects of the 2 samples of diverse origin.

\section{Preparative work}

The initial step of the processing of the plant materials included percolation with $\mathrm{MeOH}$ and subsequent liquid-liquid partitioning, yielding $n$-hexane and $\mathrm{CHCl}_{3}$ fractions, which were subjected to a multistep chromatographic procedure under the guidance of MTT assays, in order to isolate the compounds responsible for the antitumour effects.

In the case of $C$. canadensis, both the $n$-hexane and the $\mathrm{CHCl}_{3}$ fractions were analysed. The crude separation of the $n$-hexane fraction, carried out by VLC, afforded 12 main fractions, among which 5 proved to be effective in the antiproliferative test. Fraction A/VII displayed an outstanding activity of 84.6-87.3\% while the others ( $A / I V, A / V, A V$ and $A / V I I I)$ exerted a cell growth inhibition of 37.1$77.2 \%$. In these fractions, the presence of unstable compounds was revealed by TLC monitoring. To avoid chemical decomposition, the subsequent procedures had to be rapid. In this respect, RPC proved to be the most suitable method. For final purification, PLC was also applied in 1 case when the separation with RPC was insufficient. As a result of the consecutive purification steps, 7 substances, identified later as acetylenes $(\mathbf{7 2}, \mathbf{7 3})$, triterpenes $(\mathbf{4 2}, \mathbf{7 7}, \mathbf{7 8})$ and sterols $[\mathbf{3 6}$ and the mixture of $\mathbf{3 7}$ and $\mathbf{3 8}$ ), were isolated. In addition, triterpene $\mathbf{4 1}$ was crystallized from the inactive fraction A/III. The structures of the isolates are presented in Annex $\mathbf{2}$.

The VLC separation of the $\mathrm{CHCl}_{3}$-soluble fraction of $C$. canadensis resulted in 5 main fractions, 4 of which were found to be effective. Since the highly active fraction $B / I$ contained earlier-isolated acetylenes $(\mathbf{7 2}, \mathbf{7 3})$, only the moderately active fractions B/II, B/III and B/IV were processed. Similarly as in the previous experiment, RPC was the method most frequently used due to its high selectivity, speed and capacity (0.1-3 g). When a more selective method and mild conditions were necessary for the final purification (separation of $\mathbf{7 4}$ and $\mathbf{7 5}$ ), RP-HPLC was applied. Chromatographic purification afforded 2 pyranone derivatives (74, 75), a flavone (13) and a fatty acid (76) (Annex 2).

The crude fractionation of the $\mathrm{CHCl}_{3}$-soluble fraction of Achillea millefolium s.l. was also achieved by VLC to furnish 8 main fractions. The antiproliferative compounds were accumulated in 3 very complex fractions (II, III and IV) containing numerous substances of different chemical types, and the presence of large amounts of chlorophyll was also a real problem. Accordingly, more selective methods were required for further chromatography. The multistep application of VLC, RPC, PLC and GF on $\mathrm{SiO}_{2}$ or Sephadex $\mathrm{LH}-20$, with a variety of solvent systems permitted the separation of the 
diverse constituents into different fractions and the removal of the redundant materials. Finally, the crystallization of the compounds facilitated the purification, allowing the isolation of 5 flavonoids (13-14, 62-64) and 5 sesquiterpene lactones (54, 79-82) (Annex 2).

The yields of the isolated compounds were in the range of 3.5-139.2 mg. Acetylenes and pyranone derivatives were obtained as oils, and the other isolates as crystals or amorphous solids. The majority of the compounds were white or colourless; exceptions were the yellow flavonoids and the brownish-yellow pyranone derivatives.

\section{Structure elucidation}

The chemical structures of the isolated compounds were determined by means of spectroscopic methods. The most important data were gained from NMR measurements. 1D NMR $\left({ }^{1} H\right.$ NMR and JMOD) spectra were recorded for all substances; the already known compounds were identified by comparision of the data obtained from these investigations with the literature values. 2D spectra $\left({ }^{1} \mathrm{H},{ }^{1} \mathrm{H}-\mathrm{COSY}, \mathrm{HSQC}, \mathrm{HMBC}\right.$ and NOESY $)$ and mass spectrometry were required for the analysis of the new structures, and in some cases for the already known compounds as well. The structure elucidation was supplemented with UV spectroscopic experiments and optical rotation measurements for the pyranone derivatives.

Twelve compounds were isolated from C. canadensis, among which 2 pyranone derivatives, conyzapyranone A (74) and conyzapyranone B (75), were described as new naturally occurring compounds. Two compounds were identified as $4 E, 8 Z$-matricaria- $\gamma$-lactone (72) and $4 Z, 8 Z$ matricaria- $\gamma$-lactone (73), typical $C_{10}$ acetylene derivatives of the genus Conyza. The previously published NMR chemical shifts recorded in $\mathrm{CCl}_{4}$ for these substances were supplemented with complete ${ }^{1} \mathrm{H}$ and ${ }^{13} \mathrm{C}$ NMR shift assignments in $\mathrm{CDCl}_{3}$. For the rare fatty acid 9,12,13-trihydroxy-10Eoctadecenoic acid (76), described for the first time in this plant, we determined complete ${ }^{13} \mathrm{C} N \mathrm{NMR}$ data. Four compounds were identified as triterpenes. Two of them, the taraxerane-type taraxerol (77) and the rare adianane-type simiarenol (78), were described for the first time in C. canadensis, while the friedelane-type friedeline (41) and epifriedelanol (42) had already been isolated from this species. Stigmasterol (37) and 6-sitosterol (38), isolated as co-crystals, and spinasterol (36) are common plant constituents, similarly to the flavone apigenin (13).

The structure analysis of compounds of $A$. millefolium s.l. led to the identification of 5 flavonoids and 5 sesquiterpenes. The known artemetin (62), casticin (63), centaureidin (64), apigenin (13), luteolin (14) and desacetylmatricarin (54) were identified on the basis of 1D NMR and UV data. The seco-pseudoguaianolides 79-81 were identified for the first time in the genus Achillea. Complete ${ }^{1} \mathrm{H}$ 
NMR shift assignments were achieved for the stereoisomers paulitin (79) and isopaulitin (80), and the previously reported ${ }^{13} \mathrm{C}$ NMR shift assignments were corrected. In the case of psilostachyin $\mathrm{C}$ (81), the earlier published ${ }^{13} \mathrm{C}$ NMR data were supplemented. Sintenin (82) was also isolated for the first time from the A. millefolium group. However, at the beginning of the structure analysis, the 1D NMR data on this substance suggested its identity to millefin (57), a compound with a germacranolide skeleton and an $\alpha$-acetyl function at C-8, as reported for A. millefoilium by KASIMOV et al. in $1972 .{ }^{147}$ In order to determine the complete NMR assignment for this compound, 2D NMR measurements were performed, which clearly indicated that the molecule bears a 6 -acetyl substitutent on C-9. The survey of the literature on germacranolides possessing this moiety led to the conclusion that the isolated compound is identical with sintenin (82), isolated previously by HATAM et al. from Achillea micrantha. ${ }^{132}$

\section{Pharmacological assessment}

Compounds from C. canadensis were tested on 3 cancerous (HeLa, MCF-7 and A-431) and 1 noncancerous (MRC-5) cell line and it was found that the antiproliferative compounds in horseweed belong to different chemical classes. The significant inhibitory effect of the $n$-hexane extracts on the proliferation of tumour cells may be attributed to $C_{10}$ acetylene, triterpene and sterol-type compounds. The lactone $\mathbf{7 3}$, epifriedelanol (42) and taraxerol (77) exhibited the highest effects $\left(\mathrm{IC}_{50}\right.$ 2.65-6.90 $\mu \mathrm{M}$ ), to an extent comparable to that of the positive control cisplatin. The most effective fraction of the extract was $A / V I I$, from which the $4 E, 8 Z$-matricaria- $\gamma$-lactone (72) was isolated in a large amount (139.2 mg). Surprisingly, 72 proved to be only moderately effective, with an $\mathrm{IC}_{50} 18.74-$ $24.46 \mu \mathrm{M}$. The relatively good activity $(84.6-87.3 \%$ at $10 \mu \mathrm{g} / \mathrm{ml}$ ) of A/VII can probably be explained by the high concentration of $4 E, 8 Z$-matricaria- $\gamma$-lactone (72) (in contrast with the other fractions, which contained much more accompanying material). Moreover, the inhibitory potency could be influenced by $4 Z, 8 Z$-matricaria- $\gamma$-lactone (73), present in a small amount in A/VII. Interestingly, friedeline (41), a close analogue of epifriedelanol (42), was found to be inactive, indicating that the hydroxy group on C-3 is an important structural requirement for the antitumour action of triterpenes. The antitumour effect of epifriedelanol (42) was earlier demonstrated in a potato disc bioassay study, ${ }^{113}$ but no cytotoxicity was observed against P-388, A-549, MCF-7, HT-29 or kB cells. ${ }^{9}$

The $\mathrm{CHCl}_{3}$ fraction displayed only moderate antiproliferative activity in the preliminary assay. However, activity-guided investigations led to the identification of active substances. In small amounts, lactones $\mathbf{7 2}$ and $\mathbf{7 3}$ were also detected in fraction B/I; these acetylenic compounds are presumably responsible for the activity of this fraction. From the other fractions, apigenin (13) 
$\left(I C_{50}\right.$ 10.64-13.88 $\left.\mu \mathrm{M}\right)$ and the new conyzapyranone $A(74)$ and $B(75)\left(I C_{50} 31.83-61.40 \mu \mathrm{M}\right)$ were isolated as antitumour substances. In the active fraction B/IV, the ineffective fatty acid $\mathbf{7 6}$ was isolated besides unstable compounds. The antitumour action can probably be attributed to these unknown substances, which could not be isolated in pure form.

The selective cytotoxic activity of new anticancer drug candidates, natural or synthetic, is one of their most critical pharmacological features. Although an ideal anticancer agent is expected not to suppress the proliferation of intact cells, most of the currently used agents, including doxorubicin and cisplatin, are clearly toxic for non-cancerous cells. In our study, the $\mathrm{IC}_{50}$ values of epifriedelanol (42), spinasterol (36), and apigenin (13) indicate more pronounced toxicity on the investigated cancer cells than on MRC-5. The most interesting compound was taraxerol (77), which acts selectively on A-431 cells without any activity against non-tumorous cells.

The pharmacological assessment of compounds isolated from A. millefolium s.I. on 3 tumour cell lines (HeLa, MCF-7 and A-431) revealed that flavonoids and sesquiterpenes can be involved in the antiproliferative action of the plant. The most active compound is the flavonol centaureidin (64), with an excellent $\mathrm{IC}_{50}$ of $0.0819-0.3540 \mu \mathrm{M}$. The extremely high cytotoxicity of 64 was detected earlier by BEUTLER et al. in an in vitro screening in the $\mathrm{NCl} 60$-cell line panel. ${ }^{148}$ Interestingly, it was found that artemetin (62), a close analogue of 64, is inactive, and casticin (63) (IC $\left.\mathrm{C}_{50} 1.286-3.582 \mu \mathrm{M}\right)$, containing 3-hydroxy and 3'-methoxy groups, is 1 order of magnitude less active than 64 . This finding is in accordance with the observation that hydroxy substituents on C-3' and C-5, and methoxy groups on C-3 and C- 4 ' are necessary for maximum cytotoxic potency. ${ }^{149}$ Casticin (63) has been reported as a tubulin-binding agent that arrests the cell cycle in the G2/M phase and induces Bcl-2 depletion which favours apoptosis. ${ }^{150}$ As regards the flavones, apigenin, mentioned in the literature as a promising chemopreventive agent, ${ }^{14}$ displayed a marked antitumour effect $\left({ }^{I} C_{50}\right.$ 10.64-13.88 $\left.\mu \mathrm{M}\right)$ in our experiments, while luteolin demonstrated only a weak anticancer profile, similar to that previously reported in a variety of tumour cell systems. ${ }^{149}$

Among the sesquiterpenoids, the seco-pseudoguaianolides paulitin (79) and isopaulitin (80) are the most efficient inhibitors of tumour cell proliferation. Both compounds contain $2 \alpha, \beta$-unsaturated $\left(\mathrm{C}-\mathrm{O}-\mathrm{CH}=\mathrm{CH}_{2}\right.$ ) systems, which was earlier found to determine the cytotoxicity of SLs. ${ }^{151}$ Psilostachyin $\mathrm{C}$ (81), possessing only $1 \mathrm{C}-\mathrm{O}-\mathrm{CH}=\mathrm{CH}_{2}$ moiety in the molecule, does not exhibit an antiproliferative effect. However, the presence of an epoxy functionality and its stereochemistry most probably play important roles in the antiproliferative potency, because of the significant difference in the activities of paulitin (79) (IC $1.48-4.76 \mu \mathrm{M})$ and its stereoisomer isopaulitin (80) (IC $50.95-13.68 \mu \mathrm{M})$. 
Previous investigations indicated the cytotoxicity of compounds $\mathbf{7 9}$ and $\mathbf{8 0}$ against human breast cancer, human lung cancer, human colon cancer and human epidermoid carcinoma, with similar differences in activity. ${ }^{126}$ Interestingly, in previous work, psilostachyin C (81) was reported to cause perturbation of the mitotic spindle formation of MCF-7 cells. In the same study, psilostachyin C (81) was a more potent inhibitor of cell proliferation when the cells were previously exposed to $\gamma$-irradiation, indicating a checkpoint-inhibiting property. ${ }^{152}$ Desacetylmatricarin (54) and sintenin (82) do not meet the structural requirements for the antitumour activity of sesquiterpenes, and in line with this they were found to be inactive.

\section{Chemotaxonomic and biogenetic aspects}

Conyzapyranone A (74) and conyzapyranone B (75) were identified as new natural compounds of horseweed. Although 3-hydroxy- $\gamma$-pyranone and its derivatives have been reported to be abundant constituents of Conyza species, ${ }^{136}$ the structure of conyzapyranones, based on a $\mathrm{C}_{10}$ unsaturated carbon skeleton and having a carboxymethyl functionality, suggests a closer relationship to $C_{10}$ acetylenic compounds than to 3-hydroxy- $\gamma$-pyranone derivatives. $C_{10}$ acetylenes, including diyn-ene [e.g. lachnophyllum methyl ester (30)] or ene-diyn-ene [e.g. matricaria methyl ester (27-29)] chromophore-containing compounds and $\mathrm{C}_{10}$ lactones [e.g. lachnophyllum lactone and matricaria lactone (31)], are typical constituents of the genus Conyza. Incorporation studies have revealed that these compounds are biosynthesized from $C_{18}$ acetylenes by multistep 6 -oxidation or by direct oxidation. It has been supposed that $\mathrm{C}_{10}$ lactones can originate from $\mathrm{C}_{10}$ acetylene acids, and other $O$ heterocyclic compounds may also be biosynthesized in a similar way. ${ }^{153}$ In the cases of 74 and $\mathbf{7 5}$, cyclization of the lachnophyllum methyl ester (30) precursor can be presumed; in this cyclization, the C-4-C-8 moiety of the molecule may be involved (Figure 7).

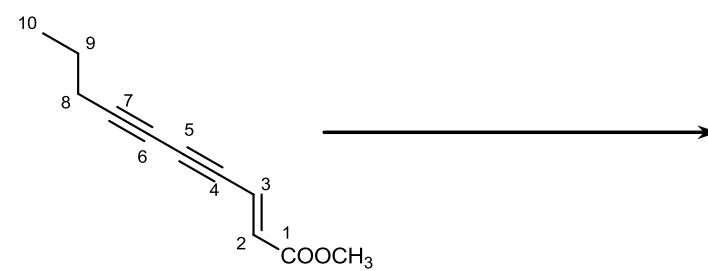

30

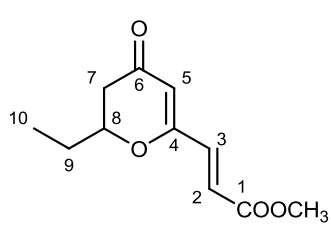

74

Figure 7. Presumed biogenesis of conyzapyranone $A$ 
It was reported earlier that the lactone $4 E, 8 Z$-matricaria- $\gamma$-lactone (73) is produced when its isomer 4Z,8Z-matricaria- $\gamma$-lactone (72) is irradiated with UV light, yielding an equilibrium mixture, and $\mathbf{7 3}$ was therefore regarded as an artefact. ${ }^{107}$ In our experiments, after the isolation of $\mathbf{7 2}$ and $\mathbf{7 3}$ in pure form, the formation of the isomeric compound was observed in both cases, suggesting an $E / Z$ isomerization process.

In contrast with our expectation that flavonols and pseuodoguaianolides are the antitumour constituents of $A$. millefolium, a previous study on the benzene extract of this plant, collected in Japan, resulted in the isolation of 3 antiproliferative 1,10-seco-guaianolides, methyl achimillate $A, B$ and $C(\mathbf{8 3 - 8 5}) .^{98}$ These results suggested the great chemical variability of the A. millefolium aggregate, besides its morphological diversity.

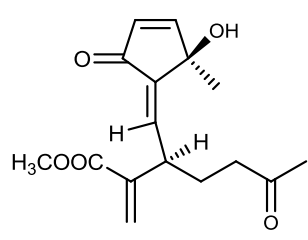

83

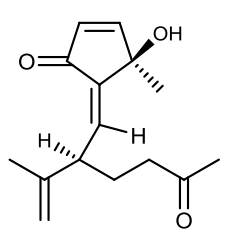

84

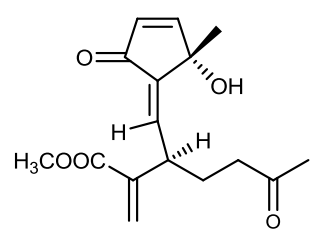

85

Paulitin (79), isopaulitin (80) and psilostachyin $C(\mathbf{8 1})$ were isolated for the first time from the Achillea genus. These seco-pseudoguaianolide-type sesquiterpene lactones were described earlier only from different Ambrosia species. ${ }^{126,128,154}$ Since the compounds were isolated from a commercial sample in our experiment, this raises the question of whether these substances are secondary metabolites of Achillea millefolium s.l. itself or arise from the impurity of the plant material. However, the yields of $\mathbf{7 9 ,} \mathbf{8 0}$ and $\mathbf{8 1}$ seem to disprove this possibility.

The study on the structure of the germacranolide sintenin (82), also isolated for the first time from the $A$. millefolium group, furnished a surprising result. The structure of millefin (57), originally presumed for AC-6, was reported by KASIMOV et al. ${ }^{147}$ in 1972 for A. millefolium; the presence of this compound has never been confirmed in any plants by other authors. Although AC-6 afforded ${ }^{1} \mathrm{H}$ and ${ }^{13} \mathrm{C}$ NMR data identical to those of 57, our 2D NMR experiments proved the structure of sintenin (82) for AC-6. The presence of millefin (57) in yarrow is therefore doubtful. 


\section{SUMMARY}

The primary aim of the present study was to evaluate the antitumour effects of Asteraceae species native to Hungary and to carry out the bioactivity-guided investigation of selected species in order to identify the compounds responsible for their antiproliferative action.

Lipophilic and hydrophilic extracts of 50 species were screened in vitro against HeLa, A-431 and MCF-7 cells, using the MTT assay. Twenty-one of the tested species were found to exert significant cell growth-inhibitory potency. Conyza canadensis, horseweed, and Achillea millefolium s.l., yarrow, were chosen for further studies.

The MeOH extracts of the plants were processed with multistep chromatographic methods (VLC, RPC, PLC, GF and HPLC) under the guidance of antiproliferative assays. Twelve compounds from $C$. canadensis and 10 from A. millefolium s.l. were isolated. The structure analysis carried out by NMR spectroscopy and mass spectrometry, and the biological assays on HeLa, A-431, MCF-7 and MRC-5 cells revealed that, in the case of $C$. canadensis, acetylene, pyranone, triterpene, sterol and flavonetype compounds are involved in the antiproliferative activity, while, in the case of $A$. millefolium s.l, the relevant compounds are flavonoids and sesquiterpenes.

From the roots of $C$. canadensis, conyzapyranone A (74), conyzapyranone B (75), 4Z,8Z-matricaria$\gamma$-lactone (72), 4E,8Z-matricaria- $\gamma$-lactone (73), apigenin (13), epifriedelanol (42), taraxerol (77), spinasterol (36) and a mixture of stigmasterol (37) and 6 -sitosterol (38) were identified as antitumour constituents, while friedeline (41), simiarenol (78) and 9,12,13-trihydroxy-10E-octadecenoic acid (76) were obtained as inactive substances. The unusual pyranone derivatives $\mathbf{7 4}$ and $\mathbf{7 5}$ are new natural compounds and the fatty acid $\mathbf{7 6}$ and triterpenes $\mathbf{7 7}$ and $\mathbf{7 8}$ were described for the first time in horseweed.

From the herbs of $A$. millefolium s.l, casticin (63), centaureidin (64), apigenin (13), luteolin (14), paulitin (79) and isopaulitin (80) were isolated as antiproliferative compounds. Artemetin (62), psilostachyin C (81), sintenin (82) and desacetylmatricarin (54) were found to be ineffective. The seco-pseudoguaianolides 79-81 in the genus Achillea, and the germacranolide $\mathbf{8 2}$ in the $A$. millefolium aggregate were described for the first time.

Our preliminary screen has provided important data on the anticancer properties of many of the Hungarian Asteracea plants and promotes the selection of further species for future work. Among the highly active species, Xanthium italicum, Anthemis ruthenica and Centaurea jacea had already been investigated at the Department of Pharmacognosy for their antitumour compounds ${ }^{155-157}$ and an activity-guided study of Onopordum acanthium is currently in progress. ${ }^{158}$ 


\section{REFERENCES}

1. Cragg, G. M.; Newman, D. J.; Snader, K. M. Natural products in drug discovery and development. J. Nat. Prod. 1997, 60, 52-60.

2. Newman, D. J.; Cragg, G. M.; Snader, K. M. Natural products as sources of new drugs over the period 1981-2002. J. Nat. Prod. 2003, 66, 1022-1037.

3. Anonymus. Label Information on Picato. http://www.accessdata.fda.gov/drugsatfda docs/label/2012/202833/bl.pdf (accessed 03/03, 2012).

4. Grothaus, P. G.; Cragg, G. M.; Newman, D. J. Plant natural products in anticancer drug discovery. Curr. Org. Chem. 2010, 14, 1781-1791.

5. Hamburger, M.; Hostettmann, K. Bioactivity in plants - the link between phytochemistry and medicine. Phytochemistry 1991, 30, 3864-3874.

6. Kintzios, S. E. What do we know about cancer and its therapy? In Plants that Fight Cancer; Kintzios, S.

E., Barberaki, M. G., Eds.; CRC Press: Boca Raton - London - New York - Washington D. C., 2004; pp 1-14.

7. Hartwell, J. Plants used against cancer: a survey. Lloydia 1968, 31, 71-170.

8. Graham, J. G.; Quinn, M. L.; Fabricant, D. S.; Farnsworth, N. R. Plants used against cancer - an extension of the work of Jonathan Hartwell. J. Ethnopharmacol. 2000, 73, 347-377.

9. Zheng, G. Q. Cytotoxic terpenoids and flavonoids from Artemisia annua. Planta Med. 1994, 60, 54-57.

10. Woerdenbag, H. J.; Merfort, I.; Passreiter, C. M.; Schmidt, T. J.; Willuhn, G.; Vanuden, W.; Pras, N.; Kampinga, H. H.; Konings, A. W. T. Cytotoxicity of flavonoids and sesquiterpene lactones from Arnica species against the Glc-4 and the Colo-320 cell lines. Planta Med. 1994, 60, 434-437.

11. Koukoulitsa, E.; Skaltsa, H.; Karioti, A.; Demetzos, C.; Dimas, K. Bioactive sesquiterpene lactones from Centaurea species and their cytotoxic/cytostatic activity against human cell lines in vitro. Planta Med. 2002, 68, 649-652.

12. Modzelewska, A.; Sur, S.; Kumar, S. K.; Khan, S. R. Sesquiterpenes: natural products that decrease cancer growth. Curr. Med. Chem. Anticancer Agents 2005, 5, 499.

13. Pan, L.; Lantvit, D. D.; Riswan, S.; Kardono, L. B. S.; Chai, H. B.; de Blanco, E. J. C.; Farnsworth, N. R.; Soejarto, D. D. I.; Swanson, S. M.; Kinghorn, A. D. Bioactivity-guided isolation of cytotoxic sesquiterpenes of Rolandra fruticosa. Phytochemistry 2010, 71, 635-640.

14. Patel, D.; Shukla, S.; Gupta, S. Apigenin and cancer chemoprevention: progress, potential and promise. Int. J. Oncol. 2007, 30, 233-245.

15. Zhang, S.,; Won, Y. K.; Ong, C. N.; Shen, H. M. Anti-cancer potential of sesquiterpenelactones: bioactivity and molecular mechanisms. Curr. Med. Chem. Anticancer Agents 2005, 5, 239-249.

16. Ghantous, A.; Gali-Muhtasib, H.; Vuorela, H. i.; Saliba, N. A.; Darwiche, N. What made sesquiterpene lactones reach cancer clinical trials? Drug Discov. Today 2010, 15, 668-678.

17. Ramasamy, K.; Agarwal, R. Multitargeted therapy of cancer by silymarin. Cancer Lett. 2008, 269, 352362.

18. Jeffrey, C. Compositae - Introduction with key to tribes. In VIII. Flowering Plants. Eudicots: Asterales; Kadereit, J. W., Jeffrey, C., Eds.; Springer-Verlag: Berlin, 2007; pp 61-86.

19. Heywood, V. H.; Harborne, J. B.; Turner, B. L. An overture to the Compositae. In The Biology and Chemistry of the Compositae; Heywood, V. H., Harborne, J. B. and Turner, B. L., Eds.; Academic Press: London - New York - San Francisco, 1977; Vol. 1, pp 1-20. 
20. Borhidi, A. Asterales - Fészekvirágzatúak. In A zárvatermök fejlődéstörténeti rendszertana; Nemzeti Tankönyvkiadó: Budapest, 1998; pp 291-295.

21. Bhom, B. A.; Stuessy, T. F. Introduction to the Sunflower family - Biology and distribution. In Flavonoids of the Sunflower Family (Asteraceae); Springer-Verlag: Wien, 2001; pp 3-17.

22. Turner, B. L. Summary of the biology of the Compositae. In The Biology and Chemistry of the Compositae; Heywood, V. H., Harborne, J. B. and Turner, B. L., Eds.; Academic Press: London - New York San Francisco, 1977; Vol. 2, pp 1105-1118.

23. Calabria, L. M.; Emerenciano, V. P.; Ferreira, M. J. P.; Scotti, M. T.; Mabry, T. J. A phylogenetic analysis of tribes of the Asteraceae based on phytochemical data. Nat. Prod. Commun. 2007, 2, 277-285.

24. Hegnauer, R. The chemistry of the Compositae. In The Biology and Chemistry of the Compositae; Heywood, V. H., Harborne, J. B. and Turner, B. L., Eds.; Academic Press: London - New York - San Francisco, 1977; Vol. 1, pp 283-335.

25. Sticher, O. Sesquiterpene. In Pharmakognosie - Phytopharmazie; Hänsel, R., Sticher, O., Eds.; Springer Medizin Verlag: Heidelberg, 2010; pp 772-807.

26. Rodriguez, E.; Towers, G. H. N.; Mitchell, J. C. Biological activities of sesquiterpene lactones. Phytochemistry 1976, 15, 1573-1580.

27. Herz, W. Sesquiterpene lactones in the Compositae. In The Biology and Chemistry of the Compositae; Heywood, V. H., Harborne, J. B. and Turner, B. L., Eds.; Academic Press: London - New York - San Francisco, 1977; Vol. 1, pp 337-358.

28. Minto, R. E.; Blacklock, B. J. Biosynthesis and function of polyacetylenes and allied natural products. Prog. Lipid Res. 2008, 47, 233-306.

29. Sørensen, N. A. Polyacetylenes and conservatism of chemical characters in the Compositae. In The Biology and Chemistry of the Compositae; Heywood, V. H., Harborne, J. B. and Turner, B. L., Eds.; Academic Press: London - New York - San Francisco, 1977; Vol. 1, pp 385-410.

30. European Directorate for the Quality of Medicines. European Pharmacopoeia 7th Edition; Council of Europe: Strasbourg, 2011.

31. Jänicke, C.; Grünwald, J.; Brendler, T. Handbuch Phytotherapie; Wissenschaftliche Verlagsgesellschaft: Stuttgart, 2003; pp 591.

32. Wagner, H. Pharmaceutical and economic uses of the Compositae. In The Biology and Chemistry of the Compositae; Heywood, V. H., Harborne, J. B. and Turner, B. L., Eds.; Academic Press: London - New York San Francisco, 1977; Vol. 1, pp 411-433.

33. Dános, B. Asteridae (Synandrae). In Farmakobotanika - A gyógynövénytan alapjai (Kemotaxonómia); Argumentum Tudományos Kiadó: Budapest, 2006; pp 312-321.

34. Van Loo, J. Inulin-type fructans as prebiotics. In Prebiotics: Development \& Application Gibson, G. R., Rastall, R. A., Eds.; John Wiley \& Sons Ltd: Chichester, 2006; pp 57-100.

35. Szabó, L. Gy.; Domokos, J.; Kiss, B. Az olajnövények. In Olajnövények, növényolajgyártás; Kiss, B., Ed.; Mezőgazda Kiadó: Budapest, 2006; pp 39-40; 74-75.

36. Gáspár, R. Éltető és gyógyító táplálékok; Heted7világ Kiadó: Budapest, 2004; , pp 167-168; 220-224.

37. Hartwell, J. Plants used against cancer: a survey. Lloydia 1967, 30, 379-436.

38. Hartwell, J. Plants used against cancer: a survey. Lloydia 1969a, 32, 79-107.

39. Hartwell, J. Plants used against cancer: a survey. Lloydia 1969b, 32, 153-205.

40. Hartwell, J. Plants used against cancer: a survey. Lloydia 1969c, 32, 247-296. 
41. Hartwell, J. Plants used against cancer: a survey. Lloydia 1970a, 33, 97-194.

42. Hartwell, J. Plants used against cancer: a survey. Lloydia 1970b, 33, 288-392.

43. Hartwell, J. Plants used against cancer: a survey. Lloydia 1971a, 34, 103-160.

44. Hartwell, J. Plants used against cancer: a survey. Lloydia 1971b, 34, 204-255.

45. Hartwell, J. Plants used against cancer: a survey. Lloydia 1971c, 34, 310-361.

46. Hartwell, J. Plants used against cancer: a survey. Lloydia 1971d, 34, 386-425.

47. Varró, A. B. Gyógynövények gyógyhatásai; Marksped Kft.: Kaposvár, 1991 (reprint); , pp 271-273-314.

48. Lonergan, G.; Routsi, E.; Georgiadis, T.; Agelis, G.; Hondrelis, J.; Matsoukas, J.; Larsen, L. K.; Caplan, F. R. Isolation, NMR studies and biological activities of onopordopicrin from Centaurea sonchifolia. J. Nat. Prod. 1992, 55, 225-228.

49. Topçu, G.; Oksuz, S.; Shieh, H. L.; Cordell, G. A.; Pezzuto, J. M.; Bozokjohansson, C. Cytotoxic and antibacterial sesquiterpenes from Inula graveolens. Phytochemistry 1993, 33, 407-410.

50. Zhou, B. N.; Bai, N. S.; Lin, L. Z.; Cordell, G. A. Sesquiterpene lactones from Inula salsoloides. Phytochemistry 1994, 36, 721-724.

51. Barrero, A. F.; Oltra, J. E.; Morales, V.; Álvarez, M.; Rodríguez-García, I. Biomimetic cyclization of cnicin to malacitanolide, a cytotoxic eudesmanolide from Centaurea malacitana. J. Nat. Prod. 1997, 60, 10341035.

52. Park, E. J.; Kim, J. Cytotoxic sesquiterpene lactones from Inula britannica. Planta Med. 1998, 64, 752754.

53. Konishi, T.; Shimada, Y.; Nagao, T.; Okabe, H.; Konoshima, T. Antiproliferative sesquiterpene lactones from the roots of Inula helenium. Biol. Pharm. Bull. 2002, 25, 1370-1372.

54. Huo, J.; Yang, S. P.; Ding, J.; Yue, J. M. Cytotoxic sesquiterpene lactones from Eupatorium lindleyanum. J. Nat. Prod. 2005, 68, 156-156.

55. Shen, Y. C.; Lo, K. L.; Kuo, Y. H.; Khalil, A. T. Cytotoxic sesquiterpene lactones from Eupatorium kiirunense, a coastal plant of Taiwan. J. Nat. Prod. 2005, 68, 745-750.

56. Xie, H. G.; Chen, H.; Cao, B.; Zhang, H. W.; Zou, Z. M. Cytotoxic germacranolide sesquiterpene from Inula cappa. Chem. Pharm. Bull. 2007, 55, 1258-1260.

57. Rüngeler, P.; Castro, V.; Mora, G.; Gören, N.; Vichnewski, W.; Pahl, H. L.; Merfort, I.; Schmidt, T. J. Inhibition of transcription factor NF-kappa B by sesquiterpene lactones: a proposed molecular mechanism of action. Bioorg. Med. Chem. 1999, 7, 2343-2352.

58. Krishna, S.; Bustamante, L.; Haynes, R. K.; Staines, H. M. Artemisinins: their growing importance in medicine. Trends Pharmacol. Sci. 2008, 29, 520-527.

59. Loizzo, M. R.; Statti, G. A.; Tundis, R.; Conforti, F.; Ando', S.; Menichini, F. Antimicrobial activity and cytotoxicity of Cirsium tenoreanum. Fitoterapia 2004, 75, 577-580.

60. Stavri, M.; Ford, C. H. J.; Bucar, F.; Streit, B.; Hall, M. L.; Williamson, R. T.; Mathew, K. T.; Gibbons, S. Bioactive constituents of Artemisia monosperma. Phytochemistry 2005, 66, 233-239.

61. Havsteen, B. H. The biochemistry and medical significance of the flavonoids. Pharmacol. Ther. 2002, $96,67-202$.

62. Prasad, S.; Phromnoi, K.; Yadav, V. R.; Chaturvedi, M. M.; Aggarwal, B. B. Targeting inflammatory pathways by flavonoids for prevention and treatment of cancer. Planta Med. 2010, 76, 1044-1063.

63. Amado, N. G.; Fonseca, F.; Cerqueira, D. M.; Neto, V. M.; Abreu, J. G. Flavonoids: potential wnt/betacatenin signaling modulators in cancer. Life Sci. 2011, 89, 545-554. 
64. Pellati, F.; Calo, S.; Benvenuti, S.; Adinolfi, B.; Nieri, P.; Melegari, M. Isolation and structure elucidation of cytotoxic polyacetylenes and polyenes from Echinacea pallida. Phytochemistry 2006, 67, 1359-1364.

65. Ukiya, M.; Akihisa, T.; Yasukawa, K.; Tokuda, H.; Suzuki, T.; Kimura, Y. Anti-inflammatory, anti-tumor promoting, and cytotoxic activities of constituents of marigold (Calendula officinalis) flowers. J. Nat. Prod. 2006, 69, 1692-1696.

66. Parra-Delgado, H.; García-Pillado, F.; Sordo, M.; Ramírez-Apan, T.; Martínez-Vázquez, M.; OstroskyWegman, P. Evaluation of the cytotoxicity, cytostaticity and genotoxicity of argentatins A and B from Parthenium argentatum Gray. Life Sci. 2005, 77, 2855-2865.

67. Calabria, L. M.; Piacente, S.; Kapusta, I.; Dharmawardhane, S. F.; Segarra, F. M.; Pessiki, P. J.; Mabry, T. J. Triterpene saponins from Silphium radula. Phytochemistry 2008, 69, 961-972.

68. Matsumoto, T.; Hosono-Nishiyama, K.; Yamada, H. Antiproliferative and apoptotic effects of butyrolactone lignans from Arctium lappa on leukemic cells. Planta Med. 2006, 72, 276-278.

69. Monks, N. R.; Ferraz, A.; Bordignon, S.; Machado, K. R.; Lima, M. F. S.; da Rocha, A. B.; Schwartsmann, G. In vitro cytotoxicity of extracts from Brazilian Asteraceae. Pharm. Biol. 2002, 40, 494-500.

70. Popoca, J.; Aguilar, A.; Alonso, D.; Villarreal, M. L. Cytotoxic activity of selected plants used as antitumorals in Mexican traditional medicine. J. Ethnopharmacol. 1998, 59, 173-177.

71. Mongelli, E.; Martino, V.; Coussio, J.; Ciccia, G. Screening of Argentine medicinal plants using the brine shrimp microwell cytotoxicity assay. Int. J. Pharmacogn. 1996, 34, 249-254.

72. Steenkamp, V.; Gouws, M. C. Cytotoxicity of six South African medicinal plant extracts used in the treatment of cancer. S. Afr. J. Bot. 2006, 72, 630-633.

73. Fouche, G.; Cragg, G. M.; Pillay, P.; Kolesnikova, N.; Maharaj, V. J.; Senabe, J. In vitro anticancer screening of South African plants. J. Ethnopharmacol. 2008, 119, 455-461.

74. de Mesquita, M. L.; de Paula, J. E.; Pessoa, C.; de Moraes, M. O.; Costa-Lotufo, L. V.; Grougnet, R.; Michel, S.; Tillequin, F.; Espindola, L. S. Cytotoxic activity of Brazilian Cerrado plants used in traditional medicine against cancer cell lines. J. Ethnopharmacol. 2009, 123, 439-445.

75. Cronquist, A. Conyza. In Flora Europea; Tutin, T. G., Heywood, V. H., Burges, N. A., Moore, D. M., Valentine, D. H., Walters, S. M. and Webb, D. A., Eds.; Cambridge University Press: Cambridge - London New York - Melbourne, 1976; Vol. 4, pp 120.

76. Weaver, S. E. The biology of Canadian weeds. Conyza canadensis. Can. J. Plant. Sci. 2001, 81, 867-875.

77. Grünwald, J. Canadian fleabane In PDR for Herbal Medicines; Wiley: Oxford, 2000; pp 144-145.

78. Li, T. S. C. Chinese and related North American herbs CRC Press: Boca Raton - London - New York Washington, 2002; , pp 179-180.

79. Bohlmann, F.; Jakupovic, J. Naturally occurring terpene derivatives.210. 8-Oxo-alpha-selinene and new scopoletin derivatives from Conyza species. Phytochemistry 1979, 18, 1367-1370.

80. Lenfeld, J.; Motl, O.; Trka, A. Anti-inflammatory activity of extracts from Conyza canadensis. Pharmazie $1986,41,268-269$.

81. Czeczot, H.; Tudek, B.; Kusztelak, J.; Szymczyk, T.; Dobrowolska, B.; Glinkowska, G.; Malinowski, J.; Strzeleck, A. H. Isolation and studies of the mutagenic activity in the Ames test of flavonoids naturally occurring in medical herbs. Mutat. Res. 1990, 240, 209-216.

82. Mukhtar, N.; Iqbal, K.; Anis, I.; Malik, A. Sphingolipids from Conyza canadensis. Phytochemistry 2002, $61,1005-1008$.

83. Mukhtar, N.; Iqbal, K.; Malik, A. Novel sphingolipids from Conyza canadensis. Chem. Pharm. Bull. 2002, 50, 1558-1560. 
84. Xie, W. D.; Gao, X.; Jia, Z. J. A new $\mathrm{C}_{10}$ acetylene and a new triterpenoid from Conyza canadensis. Arch. Pharm. Res. 2007, 30, 547-551.

85. Ding, Y.; Su, Y.; Guo, H.; Yang, F.; Mao, H.; Gao, X.; Zhu, Z.; Tu, G. Phenylpropanoyl esters from horseweed (Conyza canadensis) and their inhibitory effects on catecholamine secretion. J. Nat. Prod. 2010, 73, 270-274.

86. Hrutfiord, B. F.; Hatheway, W. H.; Smith, D. B. Essential oil of Conyza canadensis. Phytochemistry 1988, 27, 1858-1860.

87. Miyazawa, M.; Yamamoto, K.; Kameoka, H. The essential oil of Erigeron canadensis L. J. Essent. Oil. Res. 1992, 4, 227-230.

88. Curini, M.; Bianchi, A.; Epifano, F.; Bruni, R.; Torta, L.; Zambonelli, A. Composition and in vitro antifungal activity of essential oils of Erigeron canadensis and Myrtus communis from France. Chem. Nat. Compd. 2003, 39, 191-194.

89. Németh, E.; Bernáth, J. Biological activities of yarrow species (Achillea spp.). Curr. Pharm. Des. 2008, 14, 3151-3167.

90. Rauchensteiner, F.; Nejati, S.; Saukel, J. The Achillea millefolium group (Asteraceae) in Middle Europe and the Balkans: a diverse source for the crude drug herba millefolii. J. Tradit. Med 2004, 21, 113-119.

91. Simon, T. Achillea. In A magyarországi edényes flóra határozója. Harasztok - Virágos növények; Nemzeti Tankönyvkiadó Rt.: Budapest, 1992; pp 500-504.

92. Kubelka, W.; Kastner, U.; Glasl, S.; Saukel, J.; Jurenitsch, J. Chemotaxonomic relevance of sesquiterpenes within the Achillea millefolium group. Biochem. Syst. Ecol. 1999, 27, 437-444.

93. Greger, H.; Werner, A. Comparative HPLC analyses of alkamides within the Achillea millefolium group. Planta Med. 1990, 56, 482-486.

94. Richardson, I. B. K. Achillea. In Flora Europaea; Tutin, T. G., Heywood, V. H., Burges, N. A., Moore, D. M., Valentine, D. H., Walters, S. M. and Webb, D. A., Eds.; Cambridge University Press: Cambridge London - New York - Melbourne, 1976; Vol. 4, pp 159-165.

95. Kundaković, T.; Stanojković, T.; Juranić, Z.; Kovačević, N. Cytotoxic and antioxidant activity of Achillea alexandri-regis. Pharmazie 2005, 60, 319-320.

96. Trifunović, S.; Vajs, V.; Juranić, Z.; Žižak, Ž.; Tešević, V.; Macura, S.; Milosavljević, S. Cytotoxic constituents of Achillea clavennae from Montenegro. Phytochemistry 2006, 67, 887-893.

97. Gómez, M. A.; García, M. D.; Saenz, M. T.; Ahumada, M. C.; Aznar, J. Cytostatic activity of Achillea ageratum against cultured Hep-2 and McCoy cells. Pharm. Biol. 2001, 39, 79-81.

98. Tozyo, T.; Yoshimura, Y.; Sakurai, K.; Uchida, N.; Takeda, Y.; Nakai, H.; Ishii, H. Novel antitumor sesquiterpenoids in Achillea millefolium. Chem. Pharm . Bull. 1994, 42, 1096-1100.

99. Chandler, R. F.; Hooper, S. N.; Harvey, M. J. Ethnobotany and Phytochemistry of Yarrow, Achillea millefolium, Compositae. Econ. Bot. 1982, 36, 203-223.

100. Willuhn, G. Millefolii herba. In Teedrogen und Phytopharmaka - Ein Handbuch für die Praxis auf wissenschaftlicher Grundlage; Wichtl, M., Ed.; Wissenschaftliche Verlagsgesellschaft mbH: Stuttgart, 2002; pp 399-403.

101. Jurenitsch, J. Achillea. In Hagers Handbuch der Pharmazeutischen Praxis; Hänsel, R., Keller, K., Rimpler, H. and Schneider, G., Eds.; Springer-Verlag: Berlin - Heidelberg - New York, 1992; Vol. 4. Drogen A-D, pp 45-54.

102. Todorova, M. N.; Mikhova, B.; Trendafilova, A.; Vitkova, A.; Duddeck, H.; Anchev, M. Sesquiterpene lactones from Achillea asplenifolia. Biochem. Syst. Ecol. 2006, 34, 136-143. 
103. Barnes, J.; Anderson, L.; Phillipson, D. Yarrow. In Herbal Medicines; Pharmaceutical Press: London Chicago, 2007; pp 604-607.

104. Glasl, S.; Mucaji, P.; Werner, I.; Presser, A.; Jurenitsch, J. Sesquiterpenes and flavonoid aglycones from a Hungarian taxon of the Achillea millefolium group. Z. Naturforsch. C 2002, 57, 976-982.

105. Trendafilova, A.; Todorova, M.; Mikhova, B.; Duddeck, H. Flavonoids in flower heads of three Achillea species belonging to Achillea millefolium group. Chem. Nat. Compd. 2007, 43, 212-213.

106. Mosmann, T. Rapid colorimetric assay for cellular growth and survival: application to proliferation and cytotoxicity assays. J. Immunol. Methods 1983, 65, 55-63.

107. Lam, J. Polyacetylenes of Solidago virgaurea: their seasonal variation and NMR long-range spin coupling constants. Phytochem. 1971, 10, 647-653.

108. Lam, J.; Christensen, L. P.; Farch, T.; Thomasen, T. Acetylenes from the roots of Solidago species. Phytochemistry 1992, 31, 4159-4161.

109. Csupor-Löffler, B.; Hajdú, Z.; Zupkó, I.; Molnár, J.; Forgó, P.; Vasas, A.; Kele, Z.; Hohmann, J. Antiproliferative constituents of the roots of Conyza canadensis. Planta Med. 2011, 77, 1183-1188.

110. Oueslati, M. H.; Ben, J. H.; Mighri, Z.; Chriaa, J.; Abreu, P. M. Phytochemical constituents from Salsola tetrandra. J. Nat. Prod. 2006, 69, 1366-1369.

111. Mahato, S. B.; Kundu, A. P. ${ }^{13} \mathrm{C}$ NMR spectra of pentacyclic triterpenoids - a compilation and some salient features. Phytochemistry 1994, 37, 1517-1575.

112. Su, Y.; Guo, D.; Sun, M.; Zheng, J.; Liu, J.; Yang, S. Study on terpenoids from Conyza blinii. Zhongcaoyao 2001, 32, 1067-1068.

113. Kundu, J. K.; Rouf, A. S. S.; Nazmul, H. M.; Hasan,C.M., Rashid,M.A. Antitumor activity of epifriedelanol from Vitis trifolia. Fitoterapia 2000, 71, 577-579.

114. Jutiviboonsuk, A.; Zhang, H.; Kondratyuk, T. P.; Herunsalee, A.; Chaukul, W.; Pezzuto, J. M.; Fong, H. H. S.; Bunyapraphatsara, N. Isolation and characterization of cancer chemopreventive compounds from Barringtonia maunwongyathiae. Pharm. Biol. 2007, 45, 185-194.

115. Duan, J.; Wang, L.; Qian, S.; Su, S.; Tang, Y. A new cytotoxic prenylated dihydrobenzofuran derivative and other chemical constituents from the rhizomes of Atractylodes lancea D.C. Arch. Pharm. Res. 2008, 31, 965-969.

116. Ferreira, F. P.; Rodrigues de Oliveira, D. C. New constituents from Mikania laevigata Shultz Bip. ex Baker. Tetrahedron Lett. 2010, 51, 6856-6859.

117. Sacilotto, A. C. B. C.; Vichnewski, W.; Herz, W. Ent-kaurene diterpenes from Gochnatia polymorpha var polymorpha. Phytochemistry 1997, 44, 659-661.

118. Yang, Y.; Deng, Z. W.; Proksch, P.; Lin, W. H. Two new 18-en-oleane derivatives from marine mangrove plant, Barringtonia racemosa. Pharmazie 2006, 61, 365-366.

119. Yoo, N. H.; Jang, D. S.; Kim, J. S. Phytochemical constituents of the roots of Erigeron annuus. J. Korean Soc. Appl. Biol. Chem. 2008, 51, 305-308.

120. Kwon, H. C.; Choi, S. U.; Lee, K. R. Phytochemical constituents of Artemisia stolonifera. Arch. Pharm. Res. 2001, 24, 312-315.

121. Kojima, H.; Sato, N.; Hatano, A.; Ogura, H. Constituents of the Labiatae plants. 5. Sterol glucosides from Prunella vulgaris. Phytochemistry 1990, 29, 2351-2355.

122. Markham, K. R.; Geiger, H. ${ }^{1} \mathrm{H}$ nuclear magnetic resonance spectroscopy of flavonoids and their glycosides in hexadeuterodimethylsulfoxide. In The Flavonoids - Advances in Research Since 1986; Harborne, J. B., Ed.; Chapman and Hall: London, 1994; pp 441-499. 
123. Barberá, O.; Marco, J. A.; Sanz, J. F.; Sanchezparareda, J. 3-Methoxyflavones and coumarins from Artemisia incanescens. Phytochemistry 1986, 25, 2357-2360.

124. Atta-Ur-Rahman, A. D.; Choudhary, M. I.; Turkoz, S.; Sener, B. Chemical constituents of Buxus sempervirens. Planta Med. 1988, 54, 173-174.

125. Long, C.; Sauleau, P.; David, B.; Lavaud, C.; Cassabois, V.; Ausseil, F.; Massiot, G. Bioactive flavonoids of Tanacetum parthenium revisited. Phytochemistry 2003, 64, 567-569.

126. David, J. P.; Santos, A. J. D.; Guedes, M. L. D.; David, J. M.; Chai, H. B.; Pezzuto, J. M.; Angerhofer, C. K.; Cordell, G. A. Sesquiterpene lactones from Ambrosia artemisiaefolia. Pharm. Biol. 1999, 37, $165-168$.

127. Csupor-Löffler, B.; Hajdú, Z.; Zupkó, I.; Réthy, B.; Falkay, G.; Forgó, P.; Hohmann, J. Antiproliferative effect of flavonoids and sesquiterpenoids from Achillea millefolium s.l. on cultured human tumour cell lines. Phytother. Res. 2009, 23, 672-676.

128. Borges Del Castilllo, J.; Manreza-Ferrero, F. M. T.; Rodríguez-Luis, L. F.; Vázquez-Bueno, O.,P.; Nathan, J. P. ${ }^{13} \mathrm{C}$ NMR study of psilostachyinolides from some Ambrosia species. Org. Magn. Reson. 1981, 17, 232234.

129. Saltoz, M. B. V. Estudio fitoquimico de una planta dela flora del Ecuador: Ambrosia arborescens (Ph.D. thesis). 2008; Army Polytechnic School, Department of Life Sciences, Sangolquí, Ecuador

130. Solujić, S.; Sukdolak, S.; Vuković, N.; Nićiforović, N.; Stanić, S. Chemical composition and biological activity of the acetone extract of Ambrosia artemisiifolia L. pollen. J. Serb. Chem. Soc. 2008, 73, 10391049.

131. Si, X. T.; Zhang, M. L.; Shi, Q. W.; Kiyota, H. Chemical constituents of the plants in the genus Achillea. Chem. Biodivers. 2006, 3, 1163-1180.

132. Hatam, N. A. R.; Yousif, N. J.; Porzel, A.; Seifert, K. Sesquiterpene lactones from Achillea micrantha. Phytochemistry 1992, 31, 2160-2162.

133. Bruno, M.; Rosselli, S.; Raccuglia, R. A.; Maggio, A.; Senatore, F.; Apostolides Arnold, N.; Griffin,C.A., Herz,W. Terpenoids and flavones from Achillea falcata. Rev. Soc. Quim. Mexico 2003, 47, 130-131.

134. Suffness, M. S.; Pezzuto, M. J. Assays related to cancer drug discovery. In Methods in Plant Biochemistry; Dey, P. M., Harborne, J. B., Eds.; Academic Press: London, 1991; pp 71-133.

135. Li, X.; Yang, M.; Han, Y. F.; Gao, K. New sesquiterpenes from Erigeron annuus. Planta Med. 2005, 71, 268-272.

136. Li, X.; Pan, J.; Gao, K. Gamma-pyranone derivatives and other constituents from Erigeron annuus. Pharmazie 2006, 61, 474-477.

137. Nazaruk, J.; Kalemba, D. Chemical composition of the essential oils from the roots of Erigeron acris L. and Erigeron annuus (L.) Pers. Molecules 2009, 14, 2458-2465.

138. Wagner, H. Cynareae - chemical review. In The Biology and Chemistry of the Compositae; Heywood, V. H., Harborne, J. B. and Turner, B. L., Eds.; Academic Press: London - New York - San Francisco, 1977; Vol. 2, pp 1017-1038.

139. González, A. G.; Bermejo, J.; Zaragoza, T. Compositae chemistry, 43: Sesquiterpene lactones from Centaurea amara (amarin and dihydroamarin). Anal. Quim. C Quim. Org. Bioquim. 1980, 76, $296-297$.

140. Marco, J. A.; Sanservera, J. F.; Corral, J.; Carda, M.; Jakupovic, J. Xanthanolides from Xanthium absolute configuration of xanthanol, isoxanthanol and their C-4 epimers. Phytochemistry 1993, 34, 15691576.

141. Tsankova, E.; Todorova, M.; Trendafilova, A.; Robeva, P. Constituents of Xanthium italicum roots. Fitoterapia 1993, 64, 470-471. 
142. Terencio, M. C.; Sanz, M. J.; Fonseca, M. L.; Manez, S.; Rios, J. L. Phenolic compounds from Lactuca viminea L. Z. Naturforsch. C 1992, 47, 17-20.

143. Kim, M. J.; Kim, D. H.; Na, H. K.; Oh, T. Y.; Shin, C. Y.; Surh, Y. J. Eupatilin, a pharmacologically active flavone derived from Artemisia plants, induces apoptosis in human gastric cancer (AGS) cells. J. Environ. Pathol. Toxicol. Oncol. 2005, 24, 261-269.

144. Kwon, H. C.; Lee, K. R. Phytochemical constituents of Artemisia japonica ssp littoricola. Arch. Pharm. Res. 2001, 24, 194-197.

145. Ghosh, R.; Nadiminty, N.; Fitzpatrick, J. E.; Alworth, W. L.; Slaga, T. J.; Kumar, A. P. Eugenol causes melanoma growth suppression through inhibition of E2F1 transcriptional activity. J. Biol. Chem. 2005, 280, 5812-5819.

146. Khalilov, L. M.; Khalilova, A. Z.; Shakurova, E. R.; Nuriev, I. F.; Kachala, V. V.; Shashkov, A. S.; Dzhemilev, U. M. PMR and ${ }^{13} \mathrm{C}$ NMR spectra of biologically active compounds. XII. Taraxasterol and its acetate from the aerial part of Onopordum acanthium. Chem. Nat. Compd. 2003, 39, 285-288.

147. Kasymov, S. Z.; Sidyakin, G. P. Lactones of Achillea millefolium. Chem. Nat. Compd. 1972, 8, 246.

148. Beutler, J. A.; Cardellina, J. H.; Lin, C. M.; Hamel, E.; Cragg, G. M.; Boyd, M. R. Centaureidin, a cytotoxic flavone from Polymnia fruticosa, inhibits tubulin polymerization. Bioorg. Med. Chem. Lett. 1993, 3, 581-584.

149. Beutler, J. A.; Hamel, E.; Vlietinck,A,J,; Haemers, A.; Rajan, P.; Roitman, J. N.; Cardellina, J. H.; Boyd, M. R. Structure-activity requirements for flavone cytotoxicity and binding to tubulin. J. Med. Chem. 1998, 41, 2333-2338.

150. Haïdara, K.; Zamir, L.; Shi, Q. W.; Batist, G. The flavonoid casticin has multiple mechanisms of tumor cytotoxicity action. Cancer Lett. 2006, 242, 180-190.

151. Bruno, M.; Rosselli, S.; Maggio, A.; Raccuglia, R. A.; Bastow, K. F.; Lee, K. H. Cytotoxic activity of some natural and synthetic guaianolides. J . Nat. Prod. 2005, 68, 1042-1046.

152. Sturgeon, C. M.; Craig, K.; Brown, C.; Rundle, N. T.; Andersen, R. J.; Roberge, M. Modulation of the $\mathrm{G}(2)$ cell cycle checkpoint by sesquiterpene lactones psilostachyins $A$ and $C$ isolated from the common ragweed Ambrosia artemisiifolia. Planta Med. 2005, 71, 938-943.

153. Christensen, L. P.; Lam, J. Acetylenes and related compounds in Asteraceae Phytochemistry 1991, 30, 2453-2476.

154. Oberti, J. C.; Silva, G. L.; Sosa, V. E.; Kulanthaivel, P.; Herz, W. Ambrosanolides and secoambrosanolides from Ambrosia tenuifolia. Phytochemistry 1986, 25, 1355-1358.

155. Kovács, A.; Vasas, A.; Forgó, P.; Réthy, B.; Zupkó, I.; Hohmann, J. Xanthanolides with antitumour activity from Xanthium italicum. Z Naturforsch C 2009, 64, 343-349.

156. Hajdú, Z.; Zupkó, I.; Réthy, B.; Forgó, P.; Hohmann, J. Bioactivity-guided isolation of cytotoxic sesquiterpenes and flavonoids from Anthemis ruthenica. Planta Med. 2010, 76, 94-96.

157. Forgó, P.; Zupkó, I.; Molnár, J.; Vasas, A.; Dombi, G.; Hohmann, J. Bioactivity-guided isolation of antiproliferative compounds from Centaurea jacea L. Fitoterapia 2012; doi:10.1016/j.fitote.2012.04.006

158. Lajter, I.; Csupor-Löffler, B.; Zupkó, I.; Vasas, A.; Hohmann, J. Bioactivity-guided isolation of antiproliferative compounds from Onopordum acanthium (poster presentation); $8^{\text {th }}$ International Symposium on Chromatography of Natural Products, 2012; Medical University of Lublin, Poland 


\section{ACKNOWLEDGEMENTS}

This work was carried out at the Department of Pharmacognosy, University of Szeged, during period 2004-2010.

I express my deepest gratitude to my supervisors, Professor Judit Hohmann and Dr. Zsuzsanna Hajdú, for the management of my work. I am greatly obliged to them for their never-failing professional guidance and humanity, which have continually inspired me during my work.

I wish to thank Professor Imre Máthé, former director of the Department of Pharmacognosy, for providing me with all the opportunities to carry out my experiments and for his continuous support.

My special thanks are due to Dr. István Zupkó, Dr. Borbála Réthy and Dr. Judit Molnár (Department of Pharmacodynamics and Biopharmacy, University of Szeged) for the pharmacological experiments.

I am grateful to Dr Tamás Rédei (Institute of Ecology and Botany of the Hungarian Academy of Sciences, Vácrátót, Hungary) and Dr. Dóra Rédei, my colleague, for the collection and identification of the plant material; to Dr. Péter Forgó for the NMR measurements, and to Dr. Zoltán Kele (Department of Medical Chemistry, University of Szeged) and Dr. Márta Juhász (Department of Pharmaceutical Chemistry, University of Szeged) for the mass spectra.

I am very grateful to all the staff members at the Department of Pharmacognosy for their valuable help and support, and especially to Herkéné Nagy Anna, who has helped me so generously in the laboratory. I would also like to thank my colleagues, Dr. Andrea Vasas and Dr. Katalin Veres, who have always provided me with help, advice and reassurance.

Financial support from the Hungarian Scientific Research Found (OTKA 72771) is gratefully acknowledged.

I am especially grateful to Magdolna Madarász for the babysitting. I could not have carried out this work without her help.

I will forever be grateful to my family for their support and inspiration which cannot be overestimated. 


\section{APPENDICES}

The thesis is based on the following publications:

I. Réthy B, Csupor-Löffler B, Zupkó I, Hajdú Z, Máthé I, Hohmann J, Rédei T, Falkay G.

Antiproliferative activity of Hungarian Asteraceae species against human cancer cell lines. Part I

Phytotherapy Research 21: 1200-1208 (2007)

II. Csupor-Löffler B, Hajdú Z, Réthy B, Zupkó I, Máthé I, Rédei T, Falkay G, Hohmann, J.

Antiproliferative activity of Hungarian Asteraceae species against human cancer cell lines. Part II Phytotherapy Research 23: 1109-1115 (2009)

III. Csupor-Löffler B, Hajdú Z, Zupkó I, Réthy B, Falkay G, Forgo P, Hohmann J.

Antiproliferative effect of flavonoids and sesquiterpenoids from Achillea millefolium s.l. on cultured tumour cell lines

Phytotherapy Research 23: 672-676 (2009)

IV. Csupor-Löffler B, Hajdú Z, Zupkó I, Molnár, J, Forgo, P, Vasas, A, Kele, Z, Hohmann, J. Antiproliferative constituents of the roots of Conyza canadensis

Planta Medica 77: 1183-1188 (2011) 
